\title{
Subsurface mapping of Ellesmerian onlaps: Testing the opening of the Arctic Canada Basin
}

\author{
Brian Connelly \\ West Virginia University
}

Follow this and additional works at: https://researchrepository.wvu.edu/etd

\section{Recommended Citation}

Connelly, Brian, "Subsurface mapping of Ellesmerian onlaps: Testing the opening of the Arctic Canada Basin" (2006). Graduate Theses, Dissertations, and Problem Reports. 2463.

https://researchrepository.wvu.edu/etd/2463

This Thesis is protected by copyright and/or related rights. It has been brought to you by the The Research Repository @ WVU with permission from the rights-holder(s). You are free to use this Thesis in any way that is permitted by the copyright and related rights legislation that applies to your use. For other uses you must obtain permission from the rights-holder(s) directly, unless additional rights are indicated by a Creative Commons license in the record and/ or on the work itself. This Thesis has been accepted for inclusion in WVU Graduate Theses, Dissertations, and Problem Reports collection by an authorized administrator of The Research Repository @ WVU. For more information, please contact researchrepository@mail.wvu.edu. 
Subsurface mapping of Ellesmerian onlaps: testing the opening of the Arctic Canada Basin

\author{
Brian A. Connelly
}

Thesis submitted to the Eberly College of Arts and Sciences at West Virginia University in partial fulfillment of the requirements for the degree of

\title{
Master of Science in Geology
}

Thesis committee:

Jaime Toro, Ph.D. (Chair)

Richard Smosna, Ph.D.

David Oldham, Ph.D.

Department of Geology \& Geography

Morgantown, WV

2006

Keywords: Canada Basin, Rotational Opening, North Slope 


\section{ABSTRACT \\ Subsurface Mapping of Ellesmerian Onlaps: Testing the Opening of the Arctic Canada Basin}

\section{Brian A. Connelly}

Since the advent of plate tectonics in the mid-1960's the mechanism for formation of the majority of the world's ocean basins has been solved. However, there are still several remaining tectonic conundrums, such as the origin of the Arctic Canada Basin. The most widely accepted tectonic hypothesis proposes a rotational opening of the basin after rifting along the Northern Alaskan-Canadian Arctic margins.

Subsurface mapping the Ellesmerian strata of Northern Alaska onlapping onto the Barrow Arch, a long-lived basement high, was carried out and then compared with mapped strata on Prince Patrick Island, Canada, to see if they aligned. These mapped onlaps appear to show a match between Northern Alaska and the Canadian Arctic, if Northern Alaska is rotated back clockwise by $60^{\circ}$ about a Euler pole located at $68.9^{\circ} \mathrm{N}$, $229^{\circ} \mathrm{W}$. Along with recent gravity and magnetic anomaly data, all this new evidence would appear to be consistent with a rotational opening. 


\section{ACKNOWLEDGEMENTS}

I would like to thank the United States Geological Survey and Western-Geco for allowing me to use the data included in this study. Dr. Richard Smosna and Dr. David Oldham for their time and input as members of my thesis committee. And lastly I would like to the Dr. Jaime Toro for his endless help and support throughout the entire study. 


\section{TABLE OF CONTENTS}

Chapter

Page

1. INTRODUCTION 1

2. GEOLOGICAL SETTING 6

2.1 Overview 6

2.2 Alaskan North Slope Stratigraphy 9

2.3 Prince Patrick Island Stratigraphy 13

3. PROPOSED MODELS OF THE TECTONIC ORIGIN OF THE CANADA BASIN 19

$\begin{array}{ll}3.1 \text { Overview } & 19\end{array}$

3.2 Oceanization of Continental Crust 19

3.3 Entrapment of Old Oceanic Crust 21

$\begin{array}{ll}3.4 \text { Sea-Floor Spreading } & 21\end{array}$

3.4.1 Rotational Model 23

3.4.2 Arctic Islands Strike-Slip Model 26

3.4.3 Arctic Alaska Strike-Slip Model 33

3.4.4 Yukon Strike-Slip Model 36

4. GEOPHYSICS \& SEA-FLOOR SPREADING 38

4.1 Gravity 38

4.2 Magnetic Anomalies 38

5. DATA 42

5.1 Well Data $\quad 42$

5.2 Seismic Data 42

6. INTERPRETATION/RESULTS 49

7.1 Well/Seismic Interpretation 49

$\begin{array}{ll}7.2 \text { Plate Rotation } & 57\end{array}$

7. DISCUSSION 63

8. CONCLUSIONS 71

REFERENCES CITED 76

$\begin{array}{ll}\text { APPENDIX } & 77\end{array}$ 


\section{LIST OF FIGURES}

Figure 1. Map of the Arctic Basin. 2

Figure 2. Map of Prince Patrick Island. $\quad 4$

Figure 3. Rotational model. 5

$\begin{array}{lll}\text { Figure 4. } & \text { North Slope stratigraphic column. }\end{array}$

Figure 5. Stratigraphic column - North Slope vs. Sverdrup Basin strata. 8

$\begin{array}{lll}\text { Figure 6. } & \text { Basin axis map. } & 10\end{array}$

$\begin{array}{lll}\text { Figure 7. Basin axis map reconstruction. } & 10\end{array}$

Figure 8. Sverdrup Basin stratigraphic column. 15

Figure 9. Tectonic Models $\quad 20$

Figure 10. Entrapment of older oceanic crust model. 22

Figure 11. Vogt (1982) rotational model. 25

Figure 12. Distribution of structural trends map. 27

Figure 13. Distribution of structural trends reconstruction map. 27

Figure 14. Paleogeography Map. 28

Figure 15. Paleogeography reconstruction map. 28

Figure 16. $\quad$ Dutro (1981) Arctic Islands strike-slip model. 30

Figure 17. Smith (1987) Arctic Islands strike-slip model. 31

Figure 18. North Slope transform model. 34

Figure 19. Vogt (1982) transform model. 35

Figure 20. Gravity anomaly map of the Canada Basin. 39

Figure 21. Magnetic anomaly map of the Canada Basin. 40

Figure 22. Well locations in the North Slope. 44

Figure 23. Location of seismic lines in the North Slope. 45

Figure 24. Seismic line $803 . \quad 46$

Figure 25. Seismic line 783. $\quad 47$

Figure 26. Peard Well wire-line log. $\quad 50$

Figure 27. Basement map in Two-way-Time. 52

Figure 28. Isopach of Basement - Endicott Group in Two-way-Time. 54

Figure 29. Isopach of Basement - Lisburne Group in Two-way-Time. 55

Figure 30. Isopach of Basement - Sadlerochit Group in Two-way-Time. 56 
Figure 31. Isopach of Basement - Shublik Formation in Two-way-Time. 58

Figure 32. Isopach of Basement - Sag River Sandstone in Two-way-Time. 59

Figure 33. Isopach of Basement - Pebble Shale Unit in Two-way-Time 60

Figure 34. Map showing reconstructed rotation. 62

Figure 35. Map of Ellesmerian onlap edges. 64

Figure 36. Map showing reconstruction rotation, with Chukchi cap attached to Siberia (strike-slip). $\quad 66$

Figure 37. Map showing reconstruction rotation, with Chukchi cap attached to Siberia (rotation). $\quad 67$

Figure 38. Map showing alignment of Ellesmerian onlaps between Prince Patrick Island and restored Arctic Alaska. 


\section{LIST OF PLATES}

Plate 1 - Seismic Line R-4 (USGS)

Plate 2 - Seismic Line R-5 USGS) 78

Plate 3 - Seismic Line R-6 (USGS) 79

Plate 4 - Seismic Line R-11 (USGS) 80

Plate 5 - Seismic Line R-12 (USGS) 81

Plate 6 - Seismic Line R-13 (USGS) 82

Plate 7 - Seismic Line R-14 (USGS) 83

Plate 8 - Seismic Line 770 (USGS) 84

Plate 9 - Seismic Line 772 (USGS) 85

Plate 10 - Seismic Line 773 (USGS) 86

Plate 11 - Seismic Line 774 (USGS) 87

Plate 12 - Seismic Line 775 (USGS) 88

Plate 13 - Seismic Line 776 (USGS) 89

Plate 14 - Seismic Line 778 (USGS) 90

Plate 15 - Seismic Line 780 (USGS) 91

Plate 16 - Seismic Line 781 (USGS) 92

Plate 17 - Seismic Line 782 (USGS) 93

Plate 18 - Seismic Line 783 (USGS) 94

Plate 19 - Seismic Line 803 (USGS) 95

Plate 20 - Seismic Line 804 (USGS) 96

Plate 21 - Seismic Line 805 (USGS) 97

Plate 22 - Seismic Line 806 (USGS) 98

Plate 23 - Seismic Line 808 (USGS) 99

Plate 24 - Seismic Line 809 (USGS) 100

Plate 25 - Seismic Line 811 (USGS) 101

Plate 26 - Seismic Line 819 (USGS) 102

Plate 27 - Seismic Line 820 (USGS) 103

Plate 28 - Seismic Line 823 (USGS) 104

Plate 29 - Seismic Line 127 (WG) 105

Plate 30 - Seismic Line 128 (WG) 106 
Plate 31 - Seismic Line 129 (WG) 107

Plate 32 - Seismic Line 136 (WG) 108

Plate 33 - Seismic Line 137 (WG) 109

Plate 34 - Seismic Line 138 (WG) 110

Plate 35 - Seismic Line 139 (WG) 111 


\section{Chapter 1: Introduction}

Since the evolution of modern plate tectonics during the late 1960s and 1970s many of the world's major tectonic features have been resolved. However, one of the few remaining tectonic conundrums is the origin and evolution of the Canada Basin, which forms the largest and deepest basin in the Arctic Basin. The basin itself is located north of the Yukon Territories and Alaska whose coastlines mark its eastern and southern boundaries respectively. It is bordered by the East Siberian shelf off northern Russia to the west and finally by the Lomonosov ridge which runs roughly under the North Pole (Fig. 1). The part of the Arctic Basin found on the European side of Lomonosov Ridge is part of the North Atlantic rift system and is younger than 54Ma.

Due to the constant ice sheet that covers the basin's seas, little geophysical exploration and research of the oceans floors had been carried out until relatively recently in comparison to other basins. The first Ocean Drilling Program (ODP) hole in the Arctic was drilled only in 2003 on the Lomonosov Ridge (ODP Database, 2003), and was an expensive and difficult operation. The lack of solid data has left previous generations of geologists with little to work with to propose a tectonic origin and evolution of the Canada Basin. This lack of data has given rise to several hypotheses over the last 70 years, which detail the origin and evolution of the basin by different means. These various hypotheses are discussed in chapter 3. However, with new geophysical work having been carried out since the early 1990s, such as measurement of gravity and aeromagnetic anomalies, it is now possible to take several steps towards resolving the origin and evolution of the Canada Basin.

The East Siberian Shelf off northern Chukotka is the widest continental shelf 


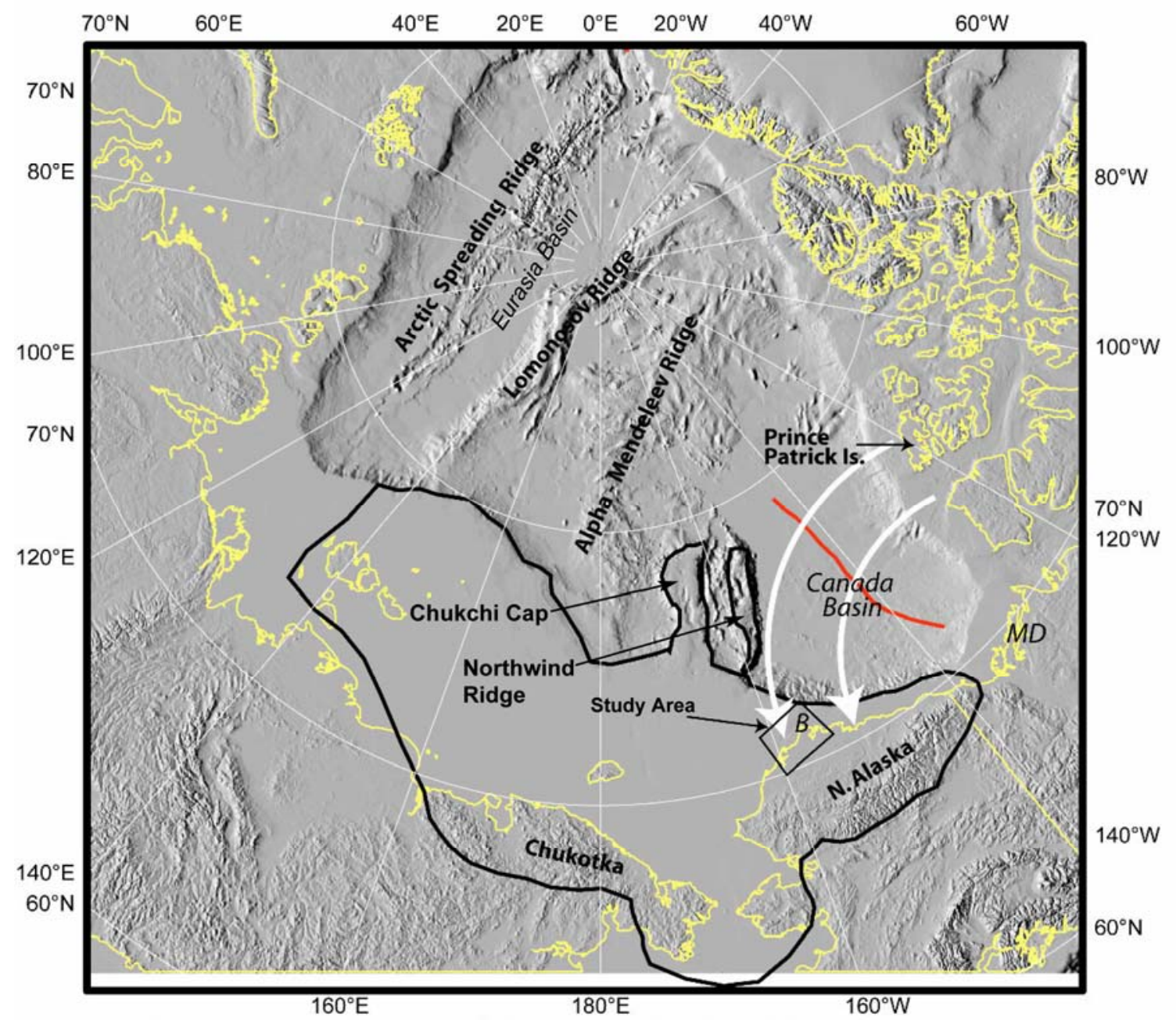

Figure 1 - Map of the Artic Basin (IBCAO, 2001) showing the location of the study area. White arrows show the possible rotation of Northern Alaska from the Canadian Arctic Archipelago. The red line is the location of the possible spreading center, based on weak magnetic anomalies in the Canada Basin. B=Barrow; MD=Mackenzie Delta. 
margin in the world, and although it is virtually unexplored, one would expect that it might contain large quantities of hydrocarbons. Knowing the tectonic nature and evolution of the Canada Basin may prove useful in future hydrocarbon exploration.

The onland geology around the basin has been used in the past to determine the tectonic evolution of the Canada Basin due to the lack of geological and geophysical data from the basin itself. The objective of this thesis is to map the Late Paleozoic-Early Mesozoic Ellesmerian strata of Alaska onlapping onto the Barrow Arch (a long-lived basement high) (Figure 1). The onlap edges are distinctive markers, which possibly may have equivalents on Prince Patrick Island, Canada, (Figure 2) where the Canadian Geological Survey has done extensive work. The mapping will be carried out using seismic and wire-line data around the Barrow Arch, North Slope of Alaska. Precise mapping of these onlaps, may provide a unique paleogeographic link between Northern Alaska and Arctic Canada, if the mapped onlaps of northern Alaska are restored to a prerotational location. The restoration of the plates will be carried out in a plate tectonic reconstruction software model, which may help to resolve the origin of the Canada Basin. The favored hypothesis of this research is for a rotational opening of the Canada Basin as suggested by Carey (1955) and later refined by Grantz et al. (1979). This model proposes that northern Alaska and the adjacent northeastern Siberia, rifted away from the Canadian Arctic Archipelago and rotated counterclockwise about a pole located in the Mackenzie Delta region (Figure 3). If this is correct, it should be possible to match the mapped onlaps of the North Slope margin to those of the Canadian Arctic. 


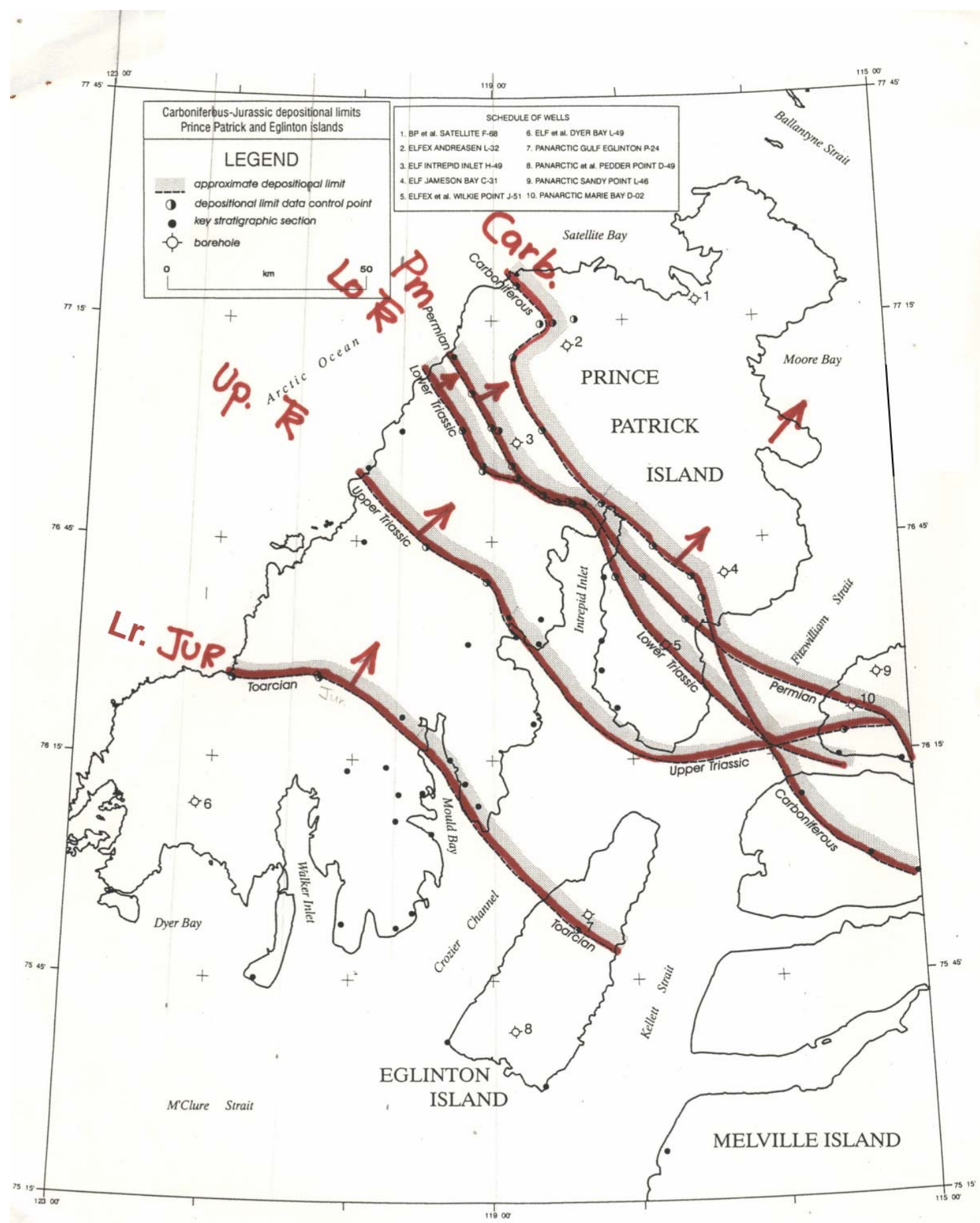

Figure 2 - Map of Prince Patrick and surrounding islands in the Canadian Sverdrup Basin showing the basement onlaps of Carboniferous-Jurassic strata. Carboniferous equivalent to the Nansen Formation; Permian equivalent Van Hauen Formation; Lower Triassic equivalent to Bjorne Formation; Upper Triassic equivalent to Schei Point Group; and Lower Jurassic is equivalent to the Heiberg Group (from Brent \& Harrison, 2004). 


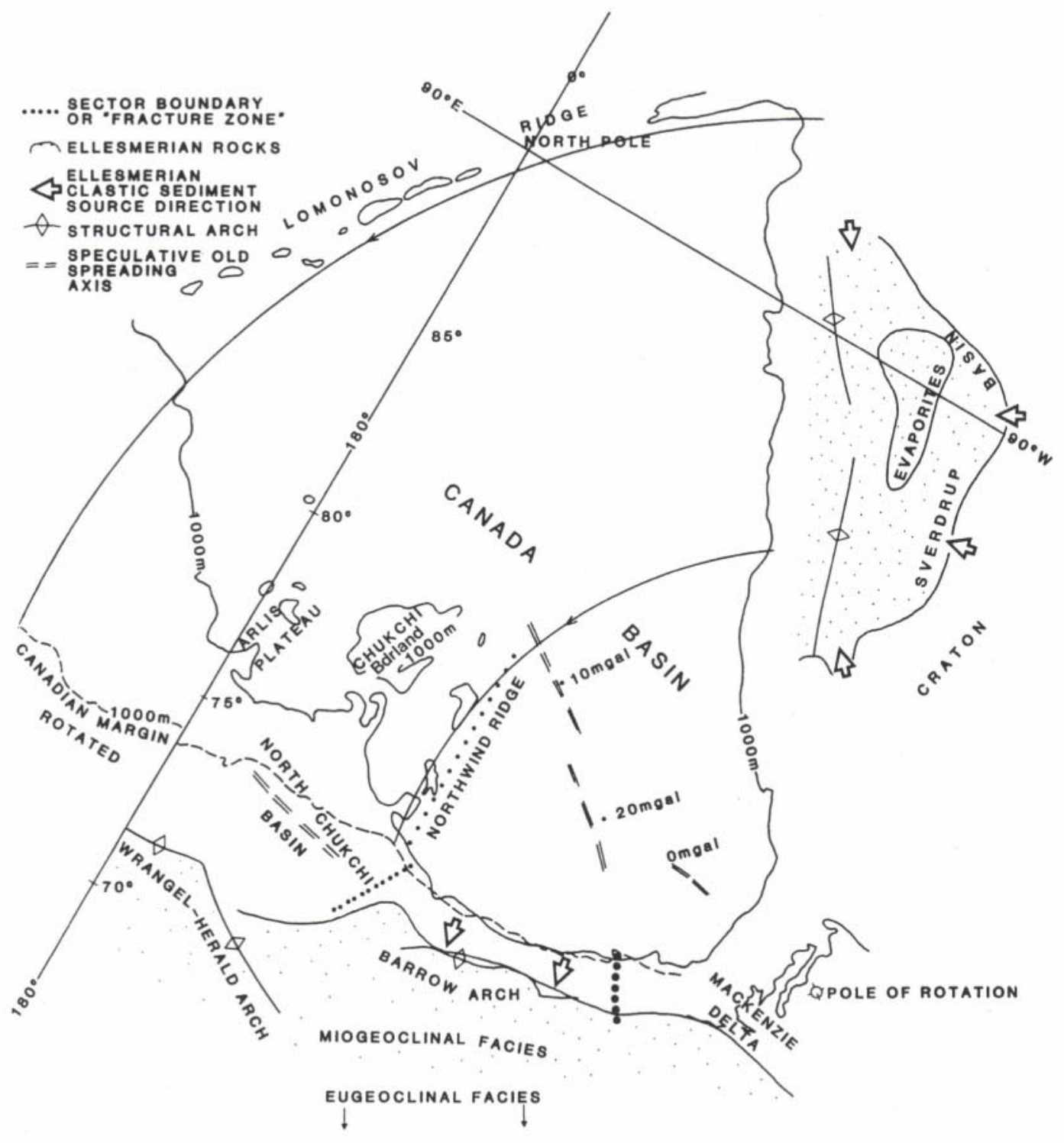

Figure 3 - Rotational model for the development of the Canada Basin redrawn from Grantz and others (1979). The $1,000 \mathrm{~m}$ bathymetric contour from the Canadian side has been rotated $66^{\circ}$ about a pole at $69.1^{\circ} \mathrm{N}, 130.5^{\circ} \mathrm{W}$. the Lomonosov Ridge nearly on a small circle about the pole of rotation as does the Northwind ridge. Hypothetical spreading center in the North Chukchi Basin indicates region from which Grantz and others (1979) suggest the Chukchi Borderland could have extended (from Lawver and Scotese, 1990). 


\section{Chapter 2: Geological Setting}

\subsection{Overview}

My research targeted the Ellesmerian (Late Paleozoic-Early Mesozoic) strata of the North Slope foreland basin, situated along the northern edge of Alaska and extending north offshore onto the Alaskan continental shelf (Figure 1) to compare with data already available from the Canadian Arctic Islands.

The North Slope foreland basin developed on a continental fragment, the Arctic Alaska plate. In early Paleozoic and early Mesozoic time, this plate was part of a passive continental margin - probably part of the North American continent north of the Canadian Arctic Islands. During Jurassic and Early Cretaceous time, rifting occurred along this margin, severing the continental connection and creating a separate plate. According to Carey’s (1955) hypothesis, drift and rotation of the plate away from North America produced the Canada basin and Beaufort passive margin. Concurrent with rifting, on the opposite side of the Arctic Alaska plate, collision with an oceanic island arc produced the Brooks Range orogen and the North Slope foreland basin (Bird and Molenaar, 1992).

The foreland basin-fill ranges in age from Early Cretaceous through Tertiary or Quaternary (Figure 4) and consists initially of orogenic deposits deposited into a foredeep flanking of the ancestral Brooks Range orogen. Followed by thick northeastwardprograding basinal, basin-slope, and shallow marine and nonmarine shelf deposits of mudstone, sandstone and conglomerate derived both from the ancestral Brooks Range orogenic belt to the south and south-west and from a source area farther to the west, now under the Chukchi Sea (Bird and Molenaar, 1992). 


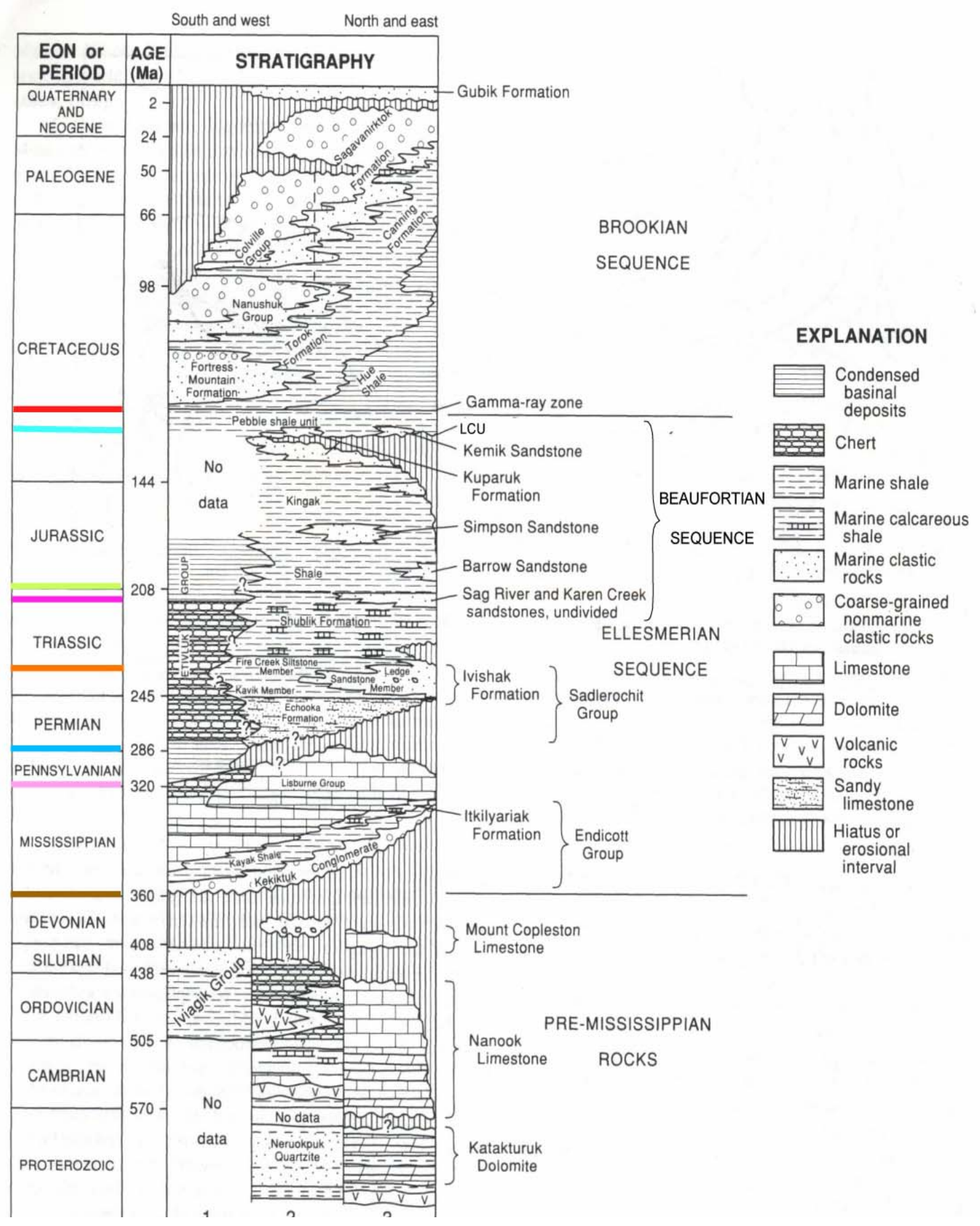

Figure 4 - Generalized stratigraphic column of North Slope subterrane (Arctic Alaska terrane). PreMississippian rocks are grouped according to region and are depicted in three subcolumns: 1, Lisburne Peninsula; 2, Romanzof Mountains; 3, Sadlerochit and Shublik mountains. Ordovician and Silurian Iviagik Group is that of Marin (1970). Jurassic Simpson and Barrow sandstones are of local usage. Brookian sequence depicts North Slope units only; less well known Brookian rocks in Lisburne Peninsula and northeastern Brooks Range are not shown (from Moore et al, 1994). 


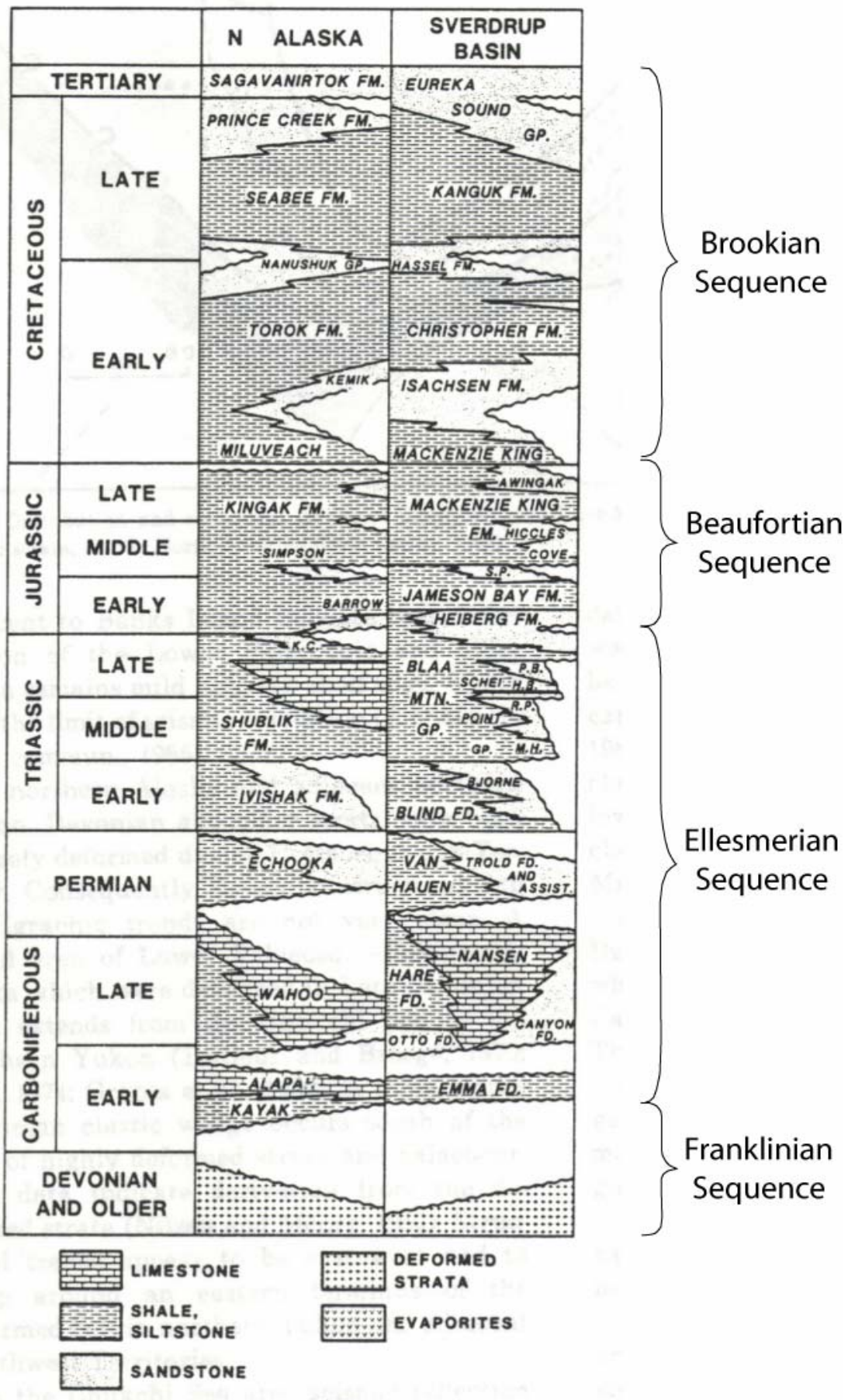

Figure 5 - Upper Paleozoic and Mesozoic strata for Northern Alaska and the Sverdrup Basin (Canadian Arctic Islands) (from Embry, 1989). 
Many previous authors (i.e. Lerand, 1973; Embry, 1989) have commented on the similarity of the stratigraphy between the North Slope of Alaska and of the Canadian Arctic Islands and cite it as evidence for the rotational opening of the Arctic Basin

(Figure 5), although, some (i.e. Jones, 1980; Dutro, 1981; Smith, 1987) have commented that this similarity fits with several of the other models regarding the opening the Arctic Basin as well.

In the Canadian Arctic Archipelago the main depocenter was the Sverdrup Basin (Balkwill, 1978). The Sverdrup Basin is a large intracratonic rift basin initiated during the late Paleozoic. Inception of the Sverdrup Basin followed the relaxation of the Ellesmerian compression and uplift in the Arctic Islands in the early Carboniferous (Morrell et al, 1995). Embry (1989) commented that rotation of Alaska would align the Sverdrup basin with that of the axis of the Hanna Trough found in northern Alaska (Figures 6 \& 7). The basin axis trends southwest in the eastern and central parts of the basin and then swings northwest in the western part, with the basin being truncated at the margin of the Canada Basin (Figure 6). In northern Alaska, the Carboniferous-Middle Jurassic strata were deposited in a basin with an axis which trends east-west on land and which then turns northward in the Chukchi Sea, the basin axis also appears to be truncated at the margin of the Canada Basin (Figure 6).

\subsection{Alaskan North Slope Stratigraphy}

The North Slope subterrane consists of a great thickness and variety of sedimentary rocks with a minor amount of igneous rocks (Figure 4). Lerand (1973) grouped 


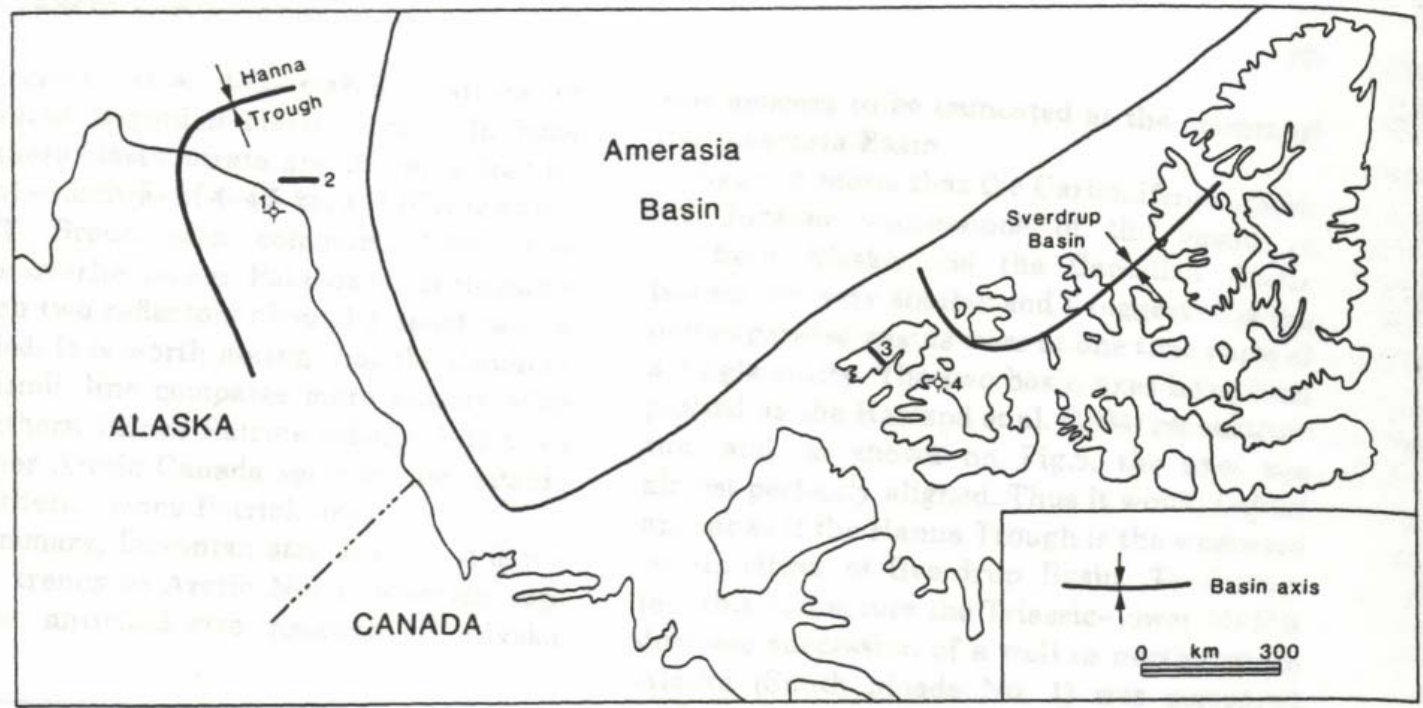

Figure 6 - Basin axes for Sverdrup Basin (Canadian Arctic Islands), Hanna Trough (Chukchi Sea) and Arctic Alaska (Northern Alaska) (from Embry, 1989).

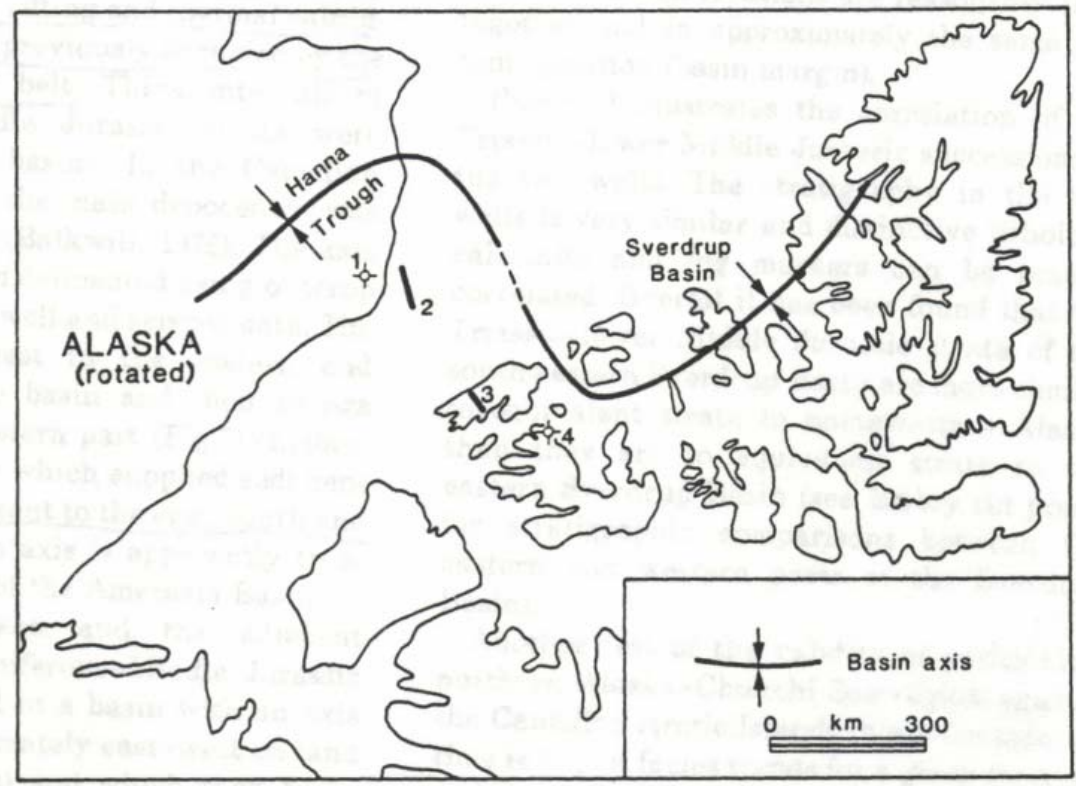

Figure 7 - Basin axes for Sverdrup Basin, Hanna Trough and Arctic Alaska plotted on pre-Cretaceous Arctic reconstruction of Harland et al. (1984). Note the juxtaposition of the Sverdrup Basin and Hanna Trough axes on this reconstruction suggesting that these basins were once part of the same through-going seaway (from Embry, 1989) 
Phanerozoic rocks of the lands bordering the Beaufort Sea into three sequences on the basis of source area and age: the Franklinian sequence (northern sources, Upper Cambrian through Devonian), Ellesmerian sequence (northern source, Mississippian to Lower Cretaceous), and Brookian sequence (southern source, Upper Jurassic or Lower Cretaceous to Holocene). Later the Beaufortian rift sequence (Jurassic to Lower Cretaceous) derived from the north, was recognized to separate the Ellesmerian from the Brookian (Hubbard et al., 1987).

The Mississippian to Triassic Ellesmerian sequence consists of carbonate and nonmarine to shallow-marine siliclastic deposits. On the Arctic platform, these are continental-shelf deposits developed on a south-facing (present day coordinate framework) passive margin; from a northern pinch-out or erosional edge, they thicken southward to a typical thickness of about 2 km (Moore et al., 1994).

Three transgressive-regressive cycles are represented by this sequence: Mississippian to Early Permian, Early Permian to Early Triassic, and Early to Late Triassic. The first and second cycles are separated by a regional unconformity, whereas the second and third cycles are separated by a local basin-margin unconformity (Moore et al., 1994).

The Mississippian to Early Permian part of the sequence constitutes a transgressive cycle which ranges in thickness from a knife edge to the north to more than 3000m thick in the south (Grantz et al, 1994). The sequence lies unconformably on top of pre-Mississippian metamorphic rocks. Initial deposits consist of nonmarine coalbearing sandstone, shale, and conglomerate (the Kekiktuk Conglomerate) that are succeeded by shallow marine black shale (Kayak Shale). This shale unit grades upwards 
and laterally into an areally extensive carbonate platform sequence of limestone and dolomite (Lisburne Group) (Bird \& Molenaar, 1992). Marine regression is thought to have occurred in the Late Pennsylvanian creating a regional unconformity at the top of the Lisburne Group.

Advance of the sea over the eroded Lisburne platform resulted in deposition of the next cycle of clastic deposits of the Permian and the Triassic Sadlerochit Group. The uppermost part of the Permian-Triassic sequence is a transgressive upward-fining marine siltstone and argillaceous sandstone unit (Fire Creek Siltstone member of the Ivishak Formation). The third cycle transgression occurred in Middle and Later Triassic time depositing a richly fossilferous shale, siltstone, mudstone and limestone units (Shublik Formation). The Shublik Formation lies unconformably on the Sadlerochit Group, separated by a local basinal unconformity. The Sag River Sandstone or Karen Creek Sandstone gradationally overlies the Shublik Formation and marks the end of the Shublik transgressive cycle (Bird \& Molenaar, 1992).

The Jurassic and Lower Cretaceous (Neocomian) Beaufortian sequence (Hubbard et al., 1987) consists of synrift deposits derived locally or from the north. This is a stratigraphically complex, mud-dominated sequence with multiple unconformities and large variations in thickness. Normal faulting and development of sediment-filled grabens and half grabens, some with more than $3 \mathrm{~km}$ of sedimentary-fill occur mainly north of the present coastline and mark the onset of rifting along the Canada Basin margin. Uplift and erosion along the rift margin resulted in formation of the regional Lower Cretaceous unconformity (LCU), this unconformity has been interpreted to be related to the breakup between the North American and Arctic Alaskan plates (Grantz \& 
May, 1983). Subsidence and an ensuing marine transgression resulted in the deposition of blanket-like marine mudstone (pebble-shale unit) that marks the end of the Beaufortian Sequence.

Cretaceous and Tertiary deposits derived from the Brooks Range orogen are assigned to the Brookian sequence. These voluminous deposits filled the North Slope foreland basin, overtopped the rift shoulder (Barrow Arch), and built the passive margin that forms the present continental terrace north of Alaska. The Brookian sequence consists of a complex assemblage of siliclastic strata that includes distal, condensed marine mudstone (Hue Shale); relatively deep marine basinal, slope, and outer-shelf mudstones and turbidite sandstones (Torok, Seabee, and Canning Formations); and shallow-marine to coal-bearing nonmarine sandstone, mudstone, and conglomerate (Nanushuk Group and Sagavanirktok Formation). The lower part of the Hue Shale, an important source rock for petroleum, is characterized by an interval of high gamma-ray readings known as the gamma-ray zone (GRZ), or the highly radioactive zone (HRZ) (Molenaar et al., 1987). This unit typically occurs in a bottomset seismic facies. However, it also interfingers with downlapping clinoform strata (Bird, 2001). Basin filling, including construction of the passive margin, occurred generally from west to east, with the exception of renewed Tertiary deposition in the northwestern part of the Chukchi Sea, possibly derived from Siberia.

\subsection{Prince Patrick Island Stratigraphy}

The three megasequences that Lerand (1973) proposed are approximately equivalent to the first three tectonic sequences of Embry (1988) in the Devonian to Cretaceous 
succession of Arctic North America (Figure 5). Both of these stratigraphic columns have similar tectonic histories, and the important Lower Cretaceous unconformity, which is believed to be related to the initiation of rotation, is also found in the Lower Cretaceous strata of Arctic Canada.

The similarity between the strata, and the seismic data available for northern Alaska may make it possible to correlate these distinctive Ellesmerian boundary units between Alaska and the Canadian Arctic Islands (Figure 2).

The strata observed on the northern half of Prince Patrick Island form the southern end of the Sverdrup basin which, like the North Slope, has a Devonian basement, and is filled with Lower Mississippian - Tertiary strata (Figure 8).

The earliest post-Franklinian strata in the Arctic islands belong to the Emma Fiord Formation of Early Carboniferous age. This formation of lacustrine shales is rich in alginite, a Type I kerogen, and is characterized as an "oil shale” at outcrop, but may be of limited distribution in the subsurface. Much more widespread around the margins of the developing basin, and possibly within the deeply buried rifts of the basin, are the red beds, sandstones and conglomerates of the Borup Fiord and Canyon Fiord formations. Of Late Carboniferous to Early Permian age, these formations mark an early phase of rapid subsidence in the basin (Morrell et al, 1995).

As marine influence increased in the Late Carboniferous and Early Permian, thick marine limestones of the Nansen and Belcher Channel formations were deposited in the northern and eastern basin and (more thinly) across the Sverdrup Rim. Reef growth occurred along the rims of the carbonate shelf. Argillaceous limestones and shales (Hare Fiord Formation) replaced evaporites in the central basin (Morrell et al, 1995). 


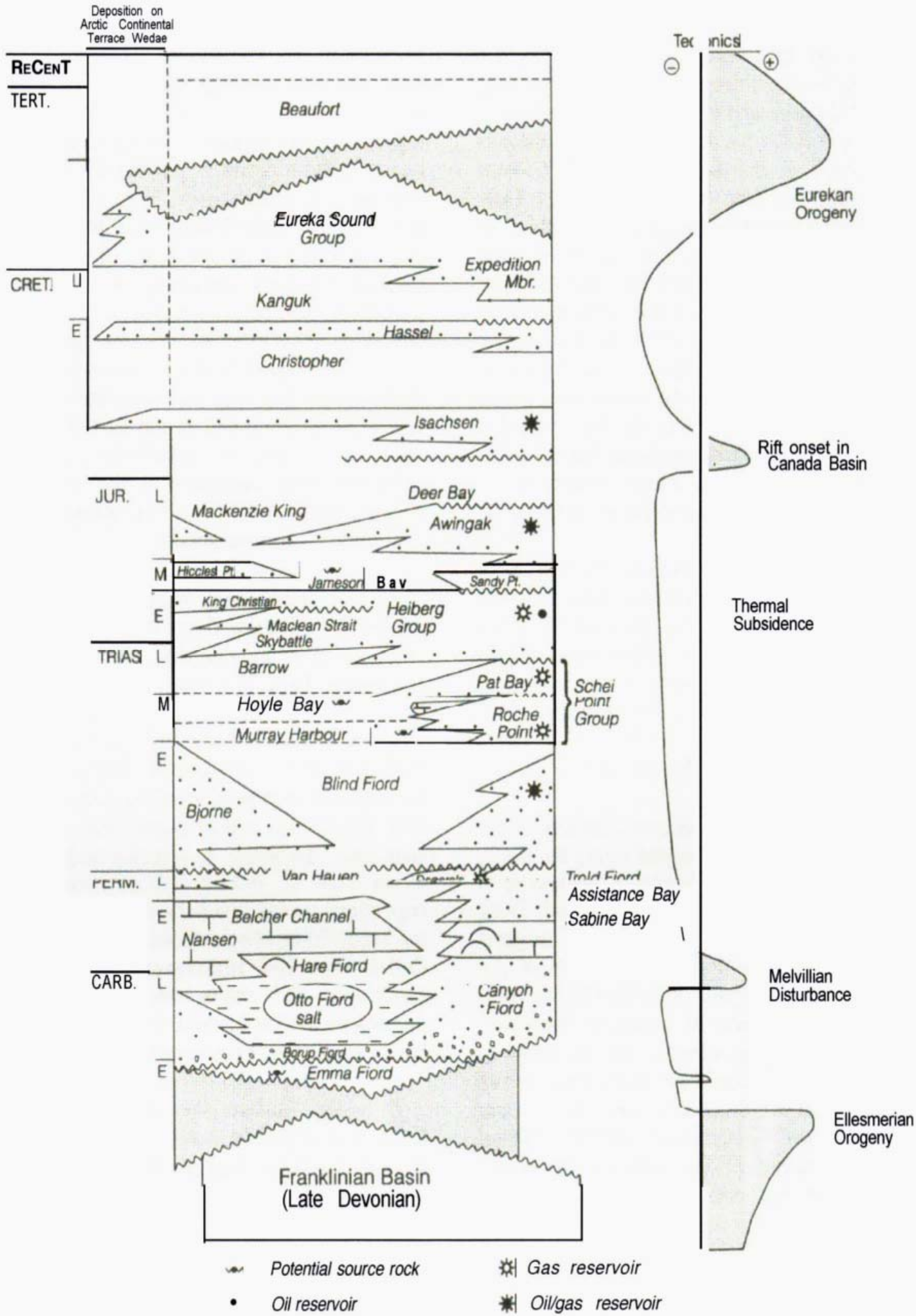

Figure 8 - Stratigraphic column for the Sverdrup Basin, also showing a subsidence curve related to tectonic events to the right (from Morrell et al, 1995). 
In the Late Permian, the shales and siltstones of the van Hauen Formation were deposited across the basin, marking the end of carbonate deposition. Sandstones of the Sabine Bay, Assistance Bay and Trold Fiord formations are proximal equivalents and suggest progradation from the northeast (Morrell et al, 1995).

The Permo-Triassic boundary is marked by an unconformity at the basin margins, but was probably conformable across much of the basin as a shale-on-shale transition. Sandstones of the Bjorne Formation (Lower Triassic) were the first major incursion of coarse clastic deltaic systems in the basin. During this period sandstones of the Sadlerochit Formation were being shed into the Alaskan North Slope Basin, possibly sourced from the same hinterland as the Bjorne. This would appear to be supported by recently completed detrital zircon data, which shows close similarities in the age distribution between zircon populations from the Triassic of the Sadlerochit Mountains (Sadlerochit Group) and Triassic sediments derived from the northern borderland of the Sverdrup Basin (Miller et al, 2006).

Subsequent deposition in the Triassic saw the advance and retreat of deltaic systems into the basin in response to the interplay of fluctuating sea levels and basin tectonics. The Roche Point and Pat Bay formations of the Schei Point Group represent modest regressions into the basin. The subsequent transgressive phase of these cycles is typified by the deposition of bioclastic shelf limestones. These deltaic advances of the Schei Point Group in the Middle to Late Triassic were the harbinger of the major advance across the basin of the deltaic systems that deposited the sandstones of the Heiberg Formation (split distally by tongues of marine shale and sequence boundary unconformities into the Skybattle, Maclean Strait and King Christian formations). The 
source for the rivers that deposited the sandstones of the Heiberg Formation was to the east of the basin. Over $1500 \mathrm{~m}$ of stacked delta-front and delta-plain sediments were deposited in the basin depocenter, which acted as a sediment trap allowing marine shale deposition to the northwest (Morrell et al, 1995).

Marine transgression in the Early Jurassic drowned the Heiberg deltas, depositing thick shales of the Jameson Bay Formation and subsequently the Mackenzie King Formation in the Middle and Late Jurassic. From the Early Jurassic onwards, deposition was increasingly affected by source areas to the northwest. By the mid-Jurassic, the basin was confined between the emergent Sverdrup Rim to the northwest and EllesmereBathurst-Melville islands to the southwest. This is most likely due to the onset of rifting, the Jurassic strata of the Canadian margin being the equivalent of the North Slope Beaufortian Sequence, which is considered to be syn-rift deposits. Shoreface sandstones were deposited on either side of this Sverdrup seaway. Significant regressions during this period deposited sandstones of the Sandy Point, Hiccles Cove and Awingak formations. Quite complex interleaving of marine/deltaic sandstones and shales developed as the relative dominance of river systems shifted to and fro across the basin, restricting the connectivity of the seaway (Morrell et al, 1995).

A major transgression at the beginning of the Cretaceous deposited shales of the Deer Bay Formation around the basin margins. There followed uplift and truncation in the Early Cretaceous. The subsequent regression deposited fluvio-deltaic sandstones (Isachsen Formation) across the basin and onto the newly formed continental margin.

From the Aptian onwards, deposition in the Sverdrup Basin became increasingly subsidiary to the building continental margin. Deposition of thick Kanguk Formation 
Shales in the Late Cretaceous reflects the flooding of continental margins worldwide during global highstand (Morrell et al, 1995).

The basal member of the Eureka Sound Group (Expedition Member) represents the final pulse of continuous sedimentation in the Sverdrup Basin. The various units of the Eureka Sound Group range in age from Campanian or Maastrichtian to Late Eocene or earliest Oligocene. The group comprises alluvial, deltaic and estuarine members which were sourced locally. The strata are rich in poorly consolidated, fine to very coarsegrained sandstones, with abundant coal. The Eureka Sound Group is deeply truncated across the Sverdrup Basin by drainage systems developed during lowstands in the Paleocene and Holocene (Morrell et al, 1995). 


\section{Chapter 3: Proposed Models of the Tectonic Origin of the Canada Basin}

\subsection{Overview}

Numerous theories concerning the tectonic origin of the Arctic Ocean, and the Canada Basin in particular, have been proposed. Previous tectonic models for the Canada Basin can be separated into three broad categories: oceanization of continental crust, entrapment of old oceanic crust, and the in-situ formation of the oceanic crust by sea-floor spreading (Figure 9).

\subsection{Oceanization of Continental Crust}

Shatskiy first proposed oceanization of continental crust to explain the origin for the basin in 1935, and this was also advocated by Beloussov in the 1950s and 1960s. Their argument was that the Canada Basin was a cratonic high that shed debris southward onto Arctic Canada and the North Slope of Alaska, and that this high was later oceanized by mantle convection that eroded the root and cause the area to subside (Lawver \& Scotese, 1990) (Figure 10).

Pogrebitskiy (1976) and Pushcharovskiy (1976) also invoked oceanization of continental crust to explain the formation of the Canada Basin, but Pogrebitskiy and others (1984) later explained the formation of the basin by a combination of lithospheric oceanization and granitization (endogenic differentiation).

This model relies on pre-plate tectonic theories and ideas, and since the plate-tectonic revolution of the 1960s, this theory has fallen out of favor and largely been discarded. 

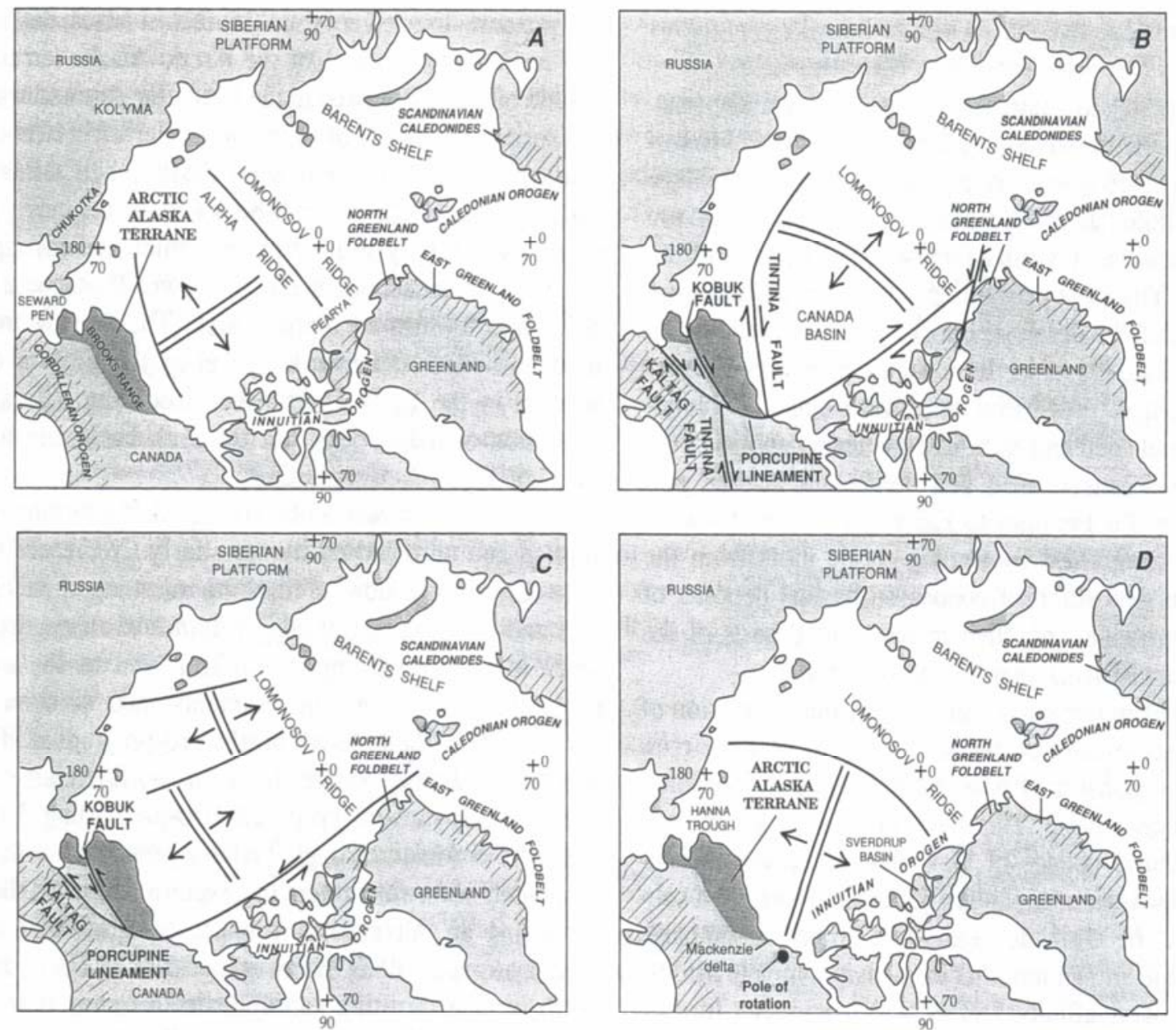

EXPLANATION

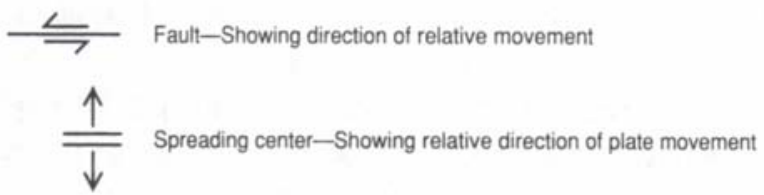

Figure 9 - Showing various Tectonic Reconstructions. A, In-situ origin: Arctic Alaska terrane is not rotated nor translated (Bogdanov and Tilman, 1964; Herron et al, 1974; Churkin \& Trexler, 1980, 1981). B, Yukon origin: Arctic Alaska terrane is translated by large-scale right slip along Tintina fault from position in northern Canadian part of Cordilleran orogen and is offset right laterally along Porcupine lineament (Jones, 1980, 1982). C, Barents Shelf origin: Arctic Alaska terrane is translated by large-scale left slip along transform fault parallel to Canadian Arctic Islands shelf edge from original position in northern Caledonian or Innutian orogens (Dutro, 1981; Nilsen, 1981; Oldow et al, 1987; Smith, 1987). D, Canadian Arctic Islands origin: Arctic Alaska terrane is rotated oroclinally from Innutian orogen about a pole of rotation near present Mackenzie delta (Carey, 1958; Tailleur, 1969, 1973; Rickwood, 1970; Newman et al, 1977; Mull, 1982; Sweeney, 1982; Grantz \& May, 1983; McWhae, 1986; Howell \& Wiley, 1987; Ziegler, 1988; Grantz et al, 1990) (from Moore et al, 1994) 


\subsection{Entrapment of Old Oceanic Crust}

The second group of models suggests that much of the Canada Basin resulted from entrapment of older oceanic crust (Lawver \& Scotese, 1990). Early Mesozoic oceanic lithosphere, traveling northward on the Kula plate, was inserted into the Arctic and during the mid-Cretaceous was cut off from the Pacific by the suturing of North America, the Kolyma terrane and Eurasia (Figure 10).

I see several problems related to this model, firstly it would require subduction along the edges of the Canada Basin during the Paleozoic into the Early Mesozoic. However, this does not appear to fit with the observed geological features at the basins margins, as the North Slope looks like a rifted margin, and the strata found at both the North Slope and along the Canadian Arctic Archipelago appear to be passive margin sequences rather than ocean trench deposits, and there is no arc volcanism of Late Paleozoic to Early Mesozoic age on the margins of the Canada Basin. Also, this model fails to explain the northern source for much of the sedimentary sequences deposited on the North Slope and Canadian Arctic Archipelago.

\subsection{Sea-Floor Spreading}

Most modern tectonic models favor the in-situ formation of the oceanic crust by seafloor spreading, but multiple geometries have been proposed. These geometries make different predictions about the nature of the North Slope margin and about it's original location.

The Canada Basin can be considered to have four sides: (1) Arctic Canada, (2) Arctic Alaska, (3) Siberia, and (4) either the Lomonosov Ridge or the Alpha and 


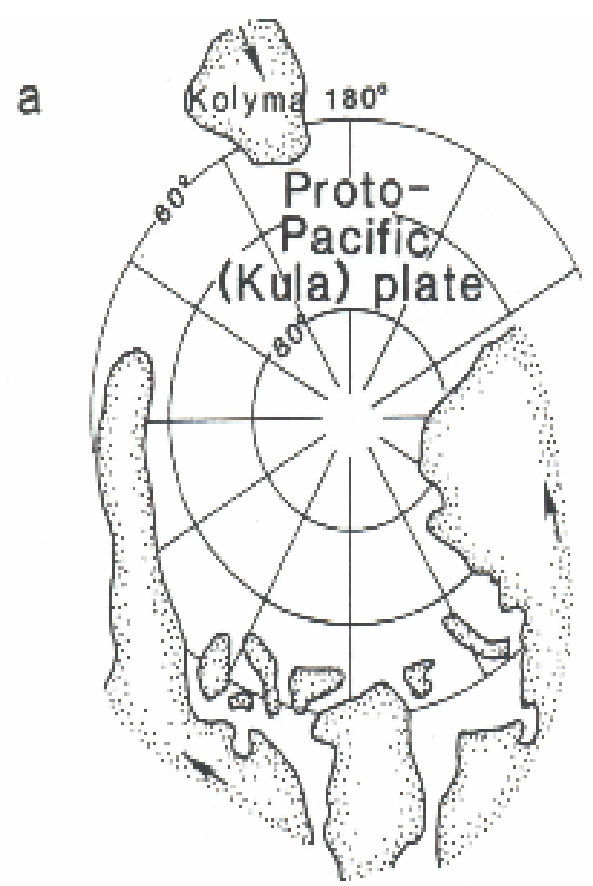

$175 \mathrm{Ma}$
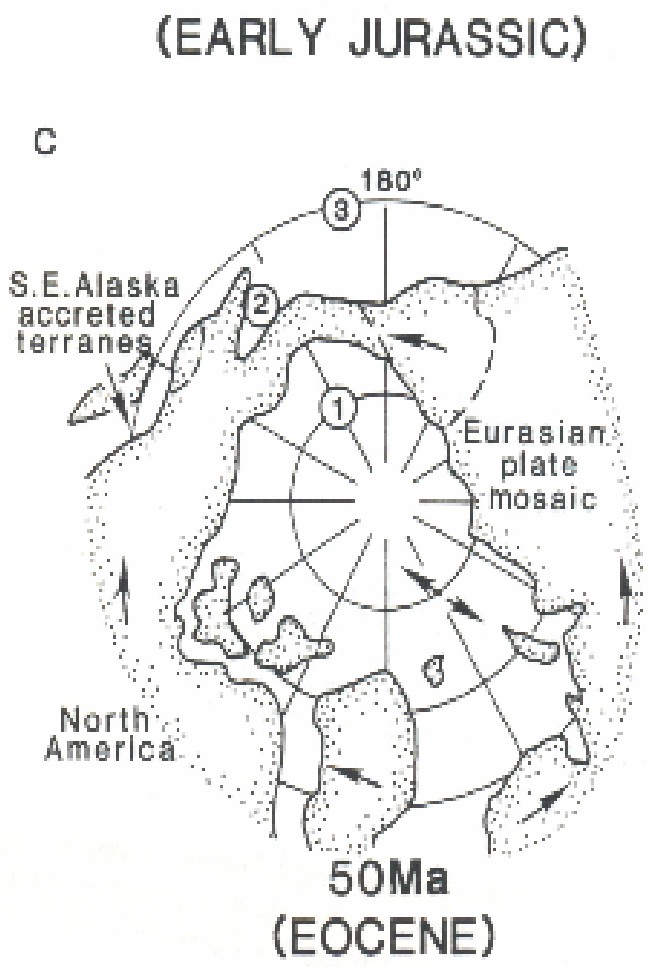

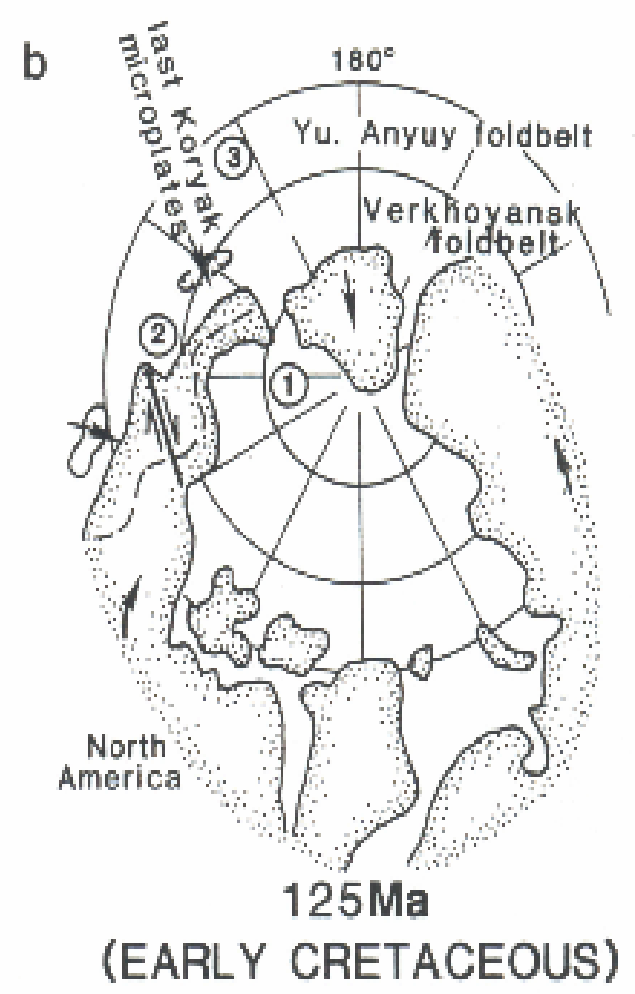

d

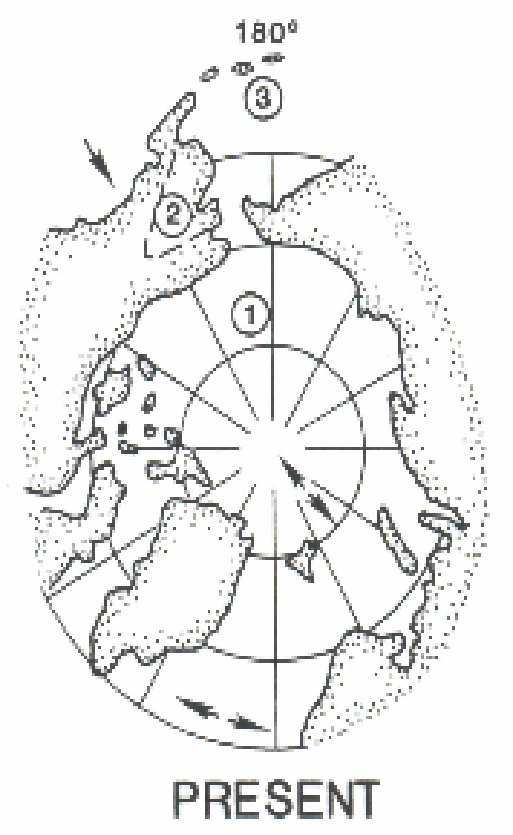

Figure 10 - Entrapment-of-older-oceanic-crust model redrawn from Churkin \& Trexler (1980). Paleogeographic reconstructions of the Arctic showing northward drift, collision, and accretion. Projection is flat polar, and shelf areas are not shown so that the land areas can be recognized. (1) indicates trapped Canada basin, (2) indicates trapped Yukon-Koyukuk region, and (3) indicates trapped Bering Sea (from Lawver \& Scotese, 1990). 
Mendeleev ridges (Figure 1). One of the most important features of the various models for the Canada Basin is the prediction that is made as to whether these margins have acted as passive or strike-slip boundaries. From this, many mutually contradictory models have been proposed with differing opinions on the nature of these margins for the Canada Basin.

\subsubsection{Rotational Model}

The first model for in-situ origin is the rotational model originally proposed by Carey in 1955 (Lawver \& Scotese, 1990), based on his concept of oroclinal bending; Carey (1955) later related it to plate tectonics. His model suggests that the Arctic Alaska block rotated away from the Canadian Arctic Islands about a pole located in the Mackenzie Delta, resulting in the observed bend in the North American cordillera where it reaches Northern Alaska (Figure 3).

Prior to the uplift of the Brooks Range, sediments on the North Slope had a northern source (present-day coordinate framework) and prograded southward. The onset of rifting in the Canada Basin was thought to coincide with 193 Ma diabase intrusives that were emplaced into a condensed sequence of Lower and Middle Jurassic chert, limestone, and oil shale (Kingak). The Jurassic rifting was a precursor to the Hauterivian breakup event that finally separated Arctic Alaska from the Canadian Arctic Islands. Restoring the Hauterivian to early Late Cretaceous paleogeography counterclockwise around a pole in the MacKenzie Delta would unite the now-separated fragments of the Jurassic failed-rift deposits into a single rift system (Grantz et al, 1994). Tailleur and Brosge (1970) dated the rotational opening of the Canada Basin as Aptian- 
Albian (119 to $97 \mathrm{Ma}$ ), with a pole of rotation located approximately $500 \mathrm{~km}$ south of the Mackenzie Delta in an attempt to resolve the change in provenance directions of North Slope sediments.

Grantz et al. (1979) rotated the $1,000 \mathrm{~m}$ isobaths by $66^{\circ}$ about a pole at $69.1^{\circ} \mathrm{N}$, $130.5^{\circ} \mathrm{W}$ and found that the coastlines from the MacKenzie delta west to the Northwind Escarpment fit well against the Canadian Arctic Islands. Those authors noted that the Lomonosov Ridge fell on a small circle about this pole of rotation, implying that the Lomonosov Ridge acted as a transform fault.

Vogt et al. (1982) suggested a similar scenario (Figure 11) for opening based on a fan-shaped set of weak magnetic anomalies in the Canada Basin (Taylor et al., 1981). In this model the North Slope of Alaska first rotated away from Arctic Canada about a pole in the Mackenzie Delta, with a younger rift splitting the Chukchi Plateau away from Arctic Canada.

Embry (1985) noted four regional unconformities in Arctic Canada that he related to the tectonic development of the Canada Basin: (1) a Middle Jurassic unconformity, followed by the development of grabens parallel to the future margin of the Canada Basin, related to the onset of rifting; (2) a Callovian (latest Middle Jurassic) unconformity, caused by a subsequent episode of rifting and graben development; (3) a widespread late valangian and early Hauterivian (Early Cretaceous) unconformity related to the onset of sea-floor spreading (during this later phase, subsidence rates along the Arctic margin increased rapidly and basalt flows appeared for the first time in the Mesozoic succession); and (4) an earliest Late Cretaceous unconformity during which uplift occurred, coincident with the final phase of basaltic volcanism. Embry (1985) 


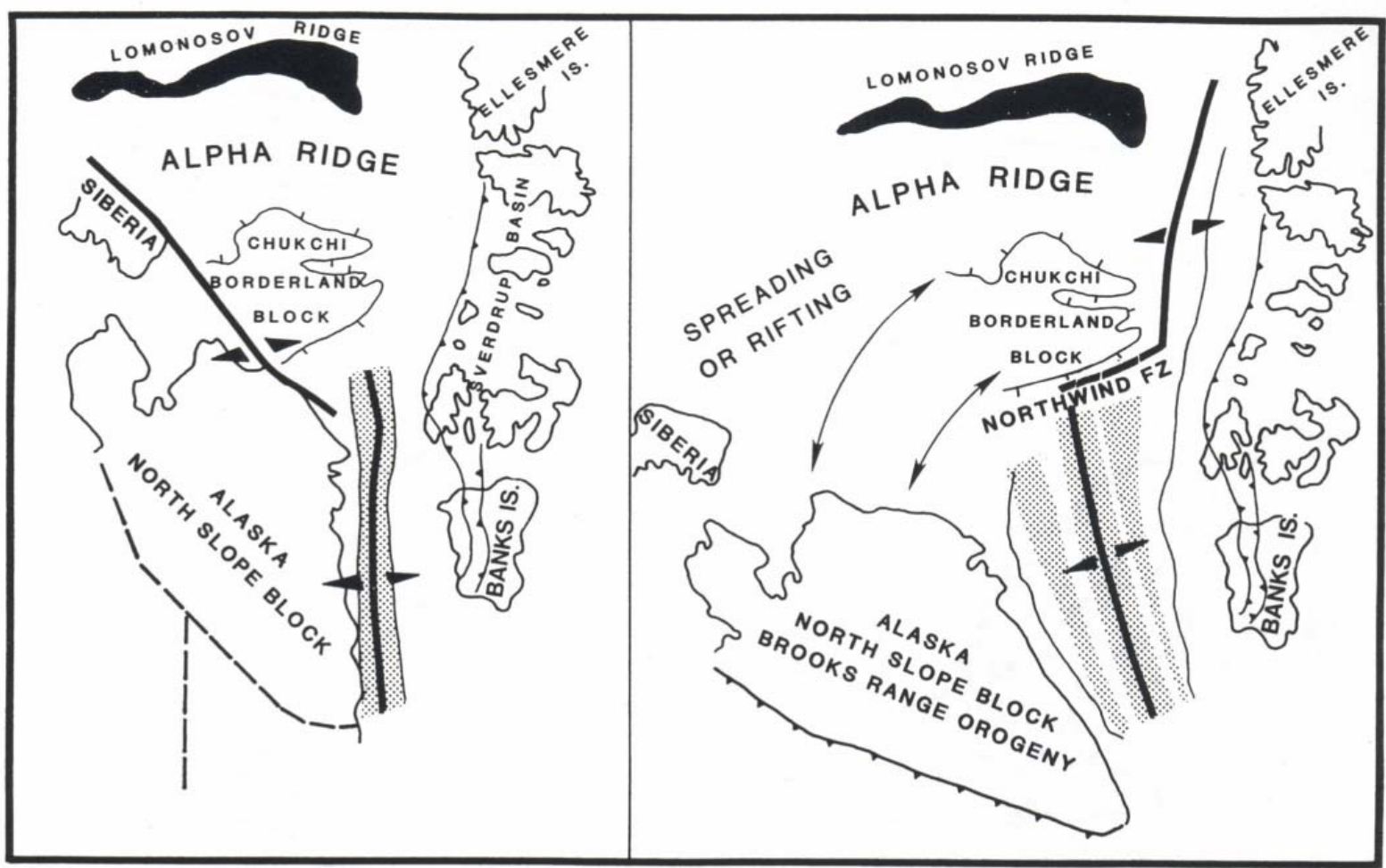

Figure 11 - Variation on the rotational model redrawn from Vogt et al (1982). The initial rifting between the Canadian Arctic Islands and Arctic Alaska only extends between the Mackenzie Delta region and the Chukchi borderland with the remainder of the extension occurring between the Chukchi Borderland an Alaska and Siberia as Hamiltion (1970) suggested. At a later time (right-hand figure), the Chukchi Borderland block also begins to move away from Arctic Canada as Alaska continues to rotate away. While they show the alpha Ridge in existence at the time of these scenarios, it is not essential to their hypothesis (from Lawver \& Scotese, 1990). 
suggested that sea-floor spreading in the Canada Basin ceased at this time and that the continental margin began to undergo thermal subsidence.

Embry (1990) also suggested that the rotational model restores the continuity of pre-drift facies trends. The axis of deposition of pre-drift Mesozoic strata (TriassicHauterivian) crosses the Canadian Arctic Islands and is truncated by the continental margin in the vicinity of Banks Island. The rotation of the North Slope block restores this truncated basin axis (Hanna Trough) on the Chukchi Shelf (Figures 6 \& 7). In addition to restoring the basin axis of the Hanna Trough and Sverdrup Basin, Embry (1990) also noted that rotation of the North Slope aligns the structural trends (Figures 12 \& 13) and the early Triassic paleogeography (Figures $14 \& 15$ ) of the North Slope and the Canadian Artic Islands.

Because of its success accounting for the tectonic history and stratigraphy of the Canadian and Alaskan margins, combined with geophysical evidence in the form of weak magnetic anomalies, this is the most widely accepted model today.

\subsubsection{Arctic Islands Strike-Slip Model}

The second model for in-situ origin, termed the Arctic Islands strike-slip model, consists of scenarios predicting that the North Slope is a passive margin that rifted from the Alpha-Mendeleev or Lomonosov ridge, which are perceived to have once been an active spreading center or formed parallel to a linear sea-floor spreading center (Lawver \& Scotese, 1990) (Figure 9). In this model, the Canadian Arctic Islands were bounded by a right-lateral transform fault.

Christie’s (1979) model suggested that during the late Paleozoic-earliest 


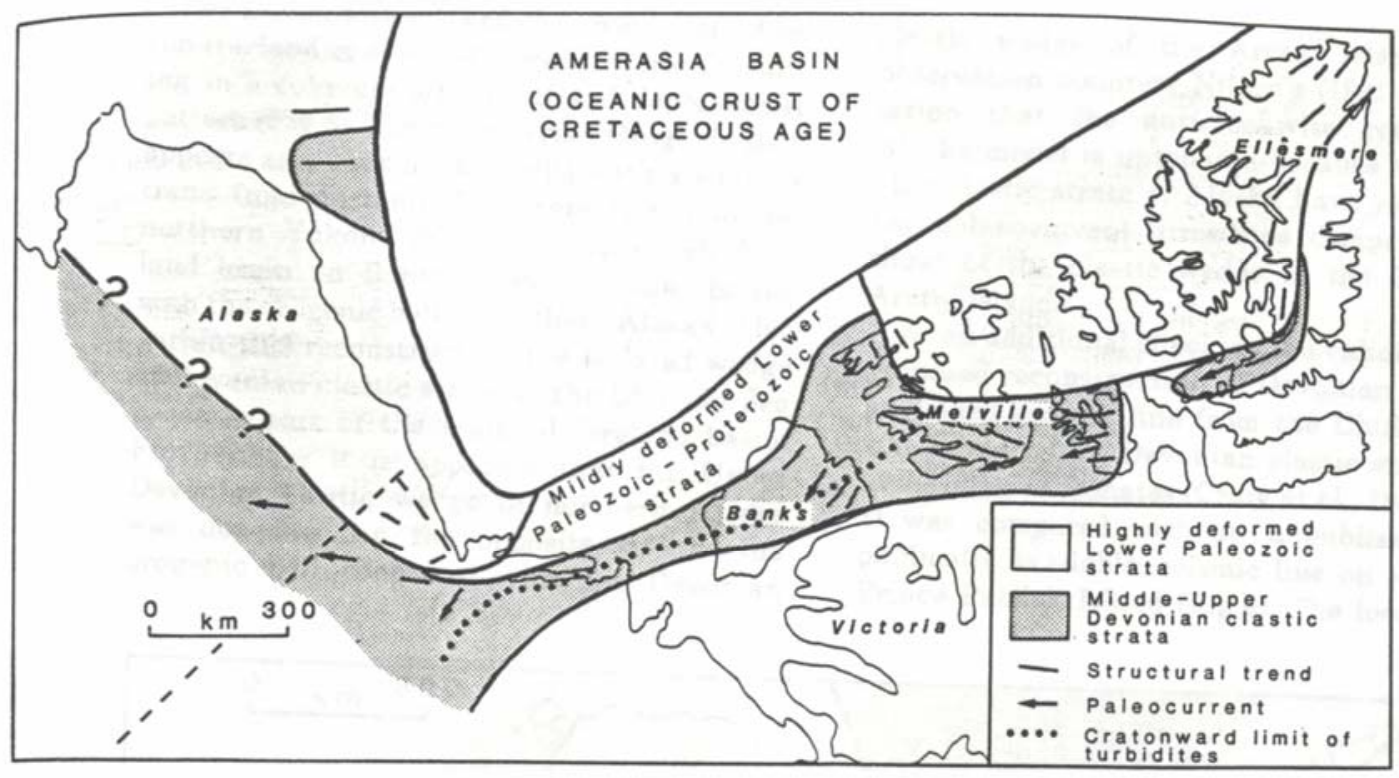

Figure 12 - Distribution and structural trends of highly deformed pre-Middle Devonian strata and Middle-Upper Devonian clastic strata, Arctic North America (from Embry, 1989).

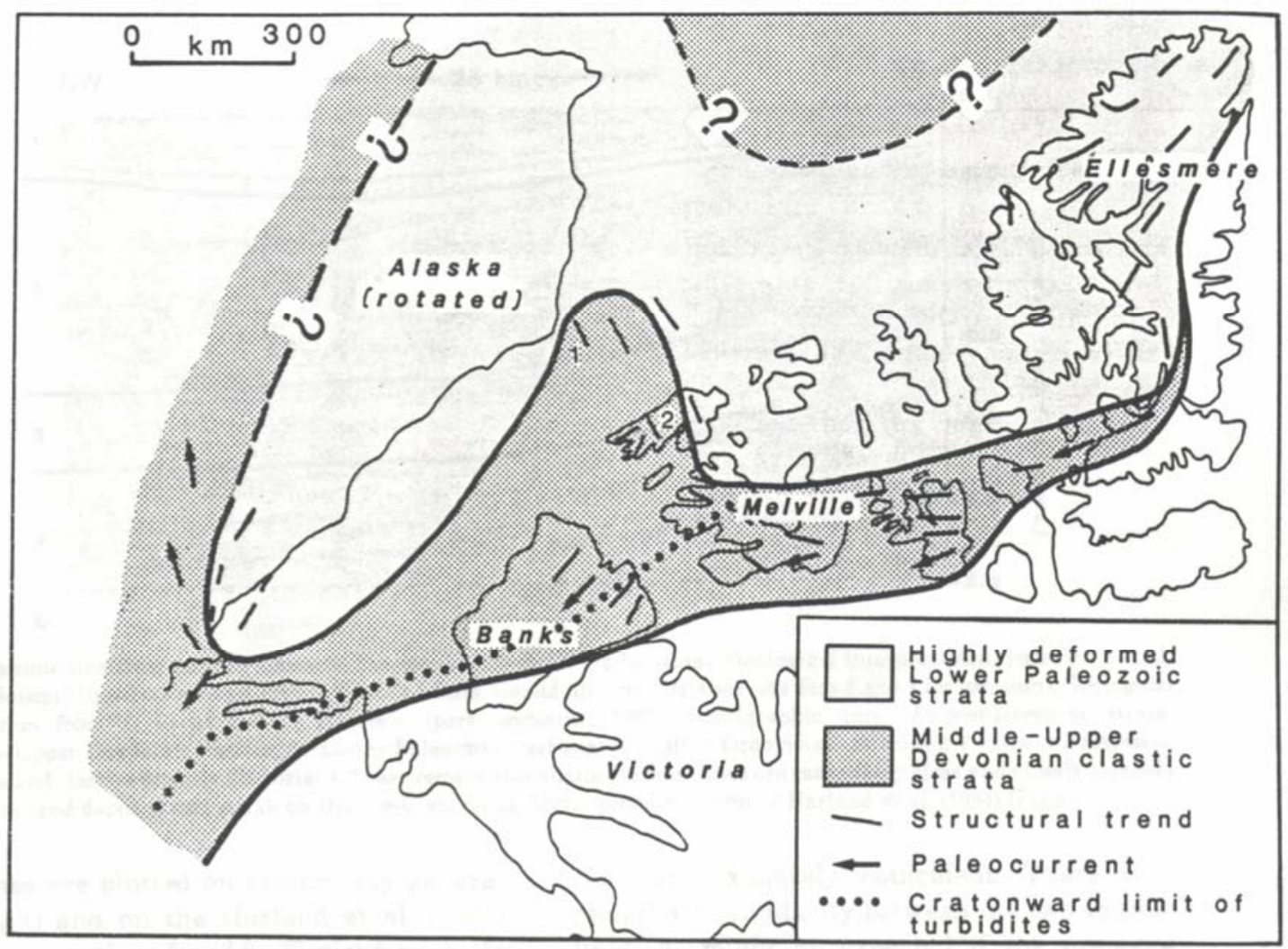

Figure 13 - Distribution and structural trends of highly deformed lower Paleozoic strata and Devonian clastic strata plotted on pre-Cretaceous Arctic reconstruction of Harland et al. (1984) (from Embry, 1989). A coherent depositional and structural picture results from using this reconstruction. 


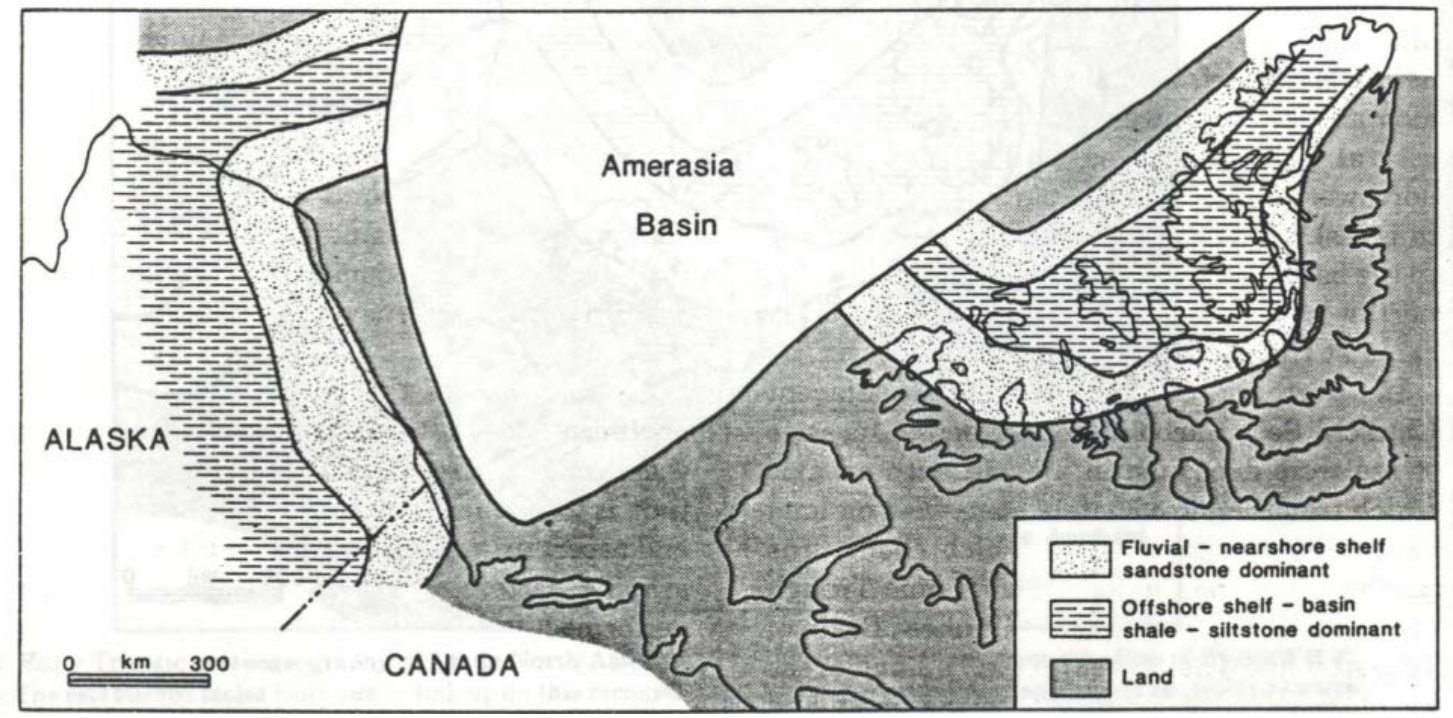

Figure 14 - Early Triassic paleogeography of Arctic North America (from Embry, 1989).

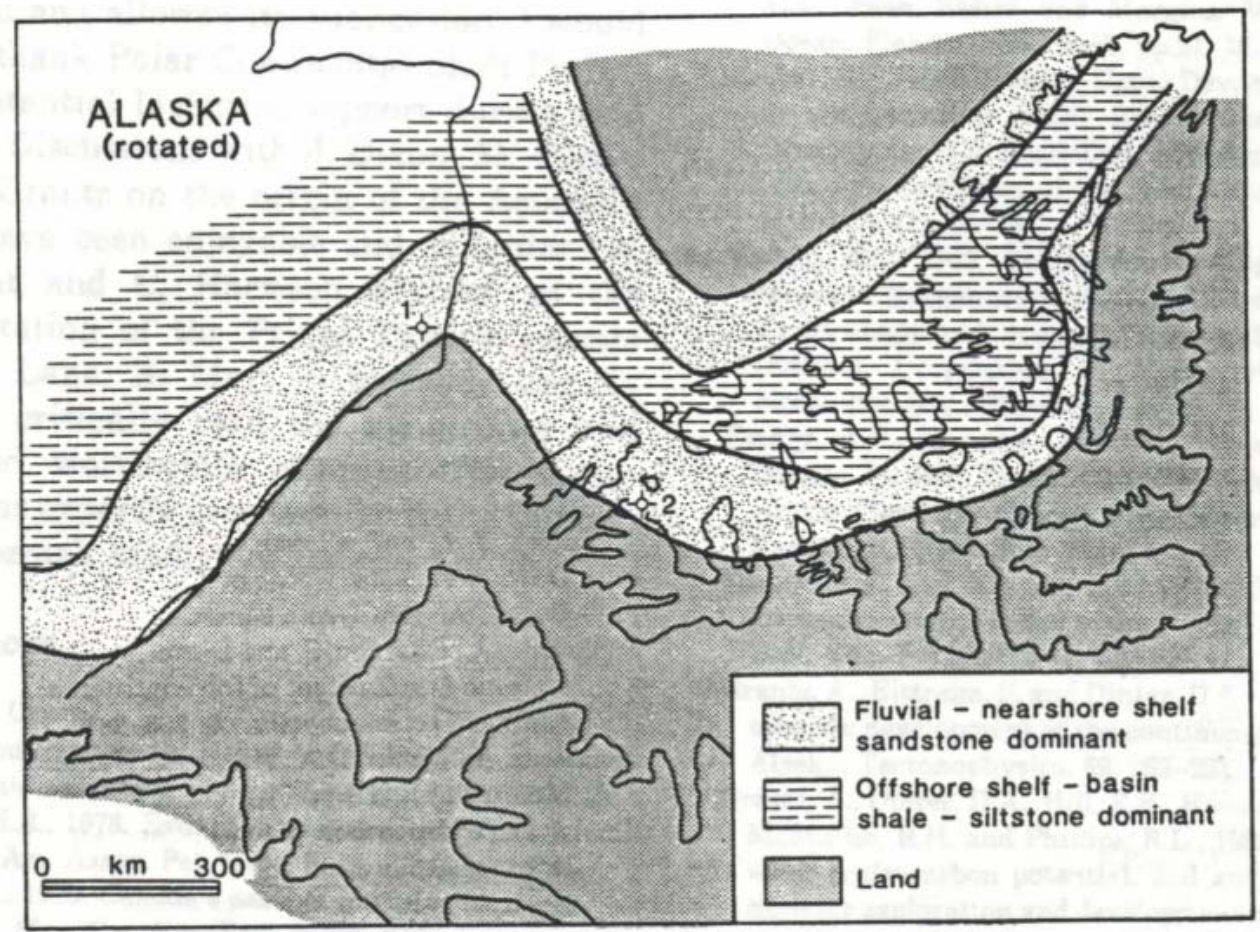

Figure 15 - Early Triassic paleogeography of Artic North America on pre-Cretaceous Arctic reconstruction of Harland et al (1984). The established facies belts neatly link up on this reconstruction as does the northern land area (Crockerland) which has been identified in the western Chukchi Sea and north of the Canadian Arctic Islands (from Embry, 1989). 
Mesozoic, rifting began in the Canada Basin either on, or parallel to, the Alpha and Mendeleev ridges. This opening produced a rifted margin along the Lomonosov Ridge, Arctic Alaska and Bering Sea splinter, and resulted in transform motion along the margin of the Canadian Arctic (Lawver \& Scotese, 1990).

In a different version of the Arctic strike-slip model, Kerr (1981) concluded that the Canada Basin is an ancient ocean basin that formed during a rifting episode in the late Paleozoic (Mississippian). Dutro (1981) indicated that a substantial Canada Basin existed prior to the early Mesozoic which was later enlarged by rifting during the Jurassic (Figure 16). The Alpha Ridge was considered by both Kerr (1981) and Dutro (1981) to be the spreading center that created the basin.

Two similar models have been proposed by Smith (1987) (Figure 17) and Crane (1987). Both models use approximately the same tectonic elements and suggest that the Canada Basin opened at about the same time (150 Ma). In both, Crane (1987) and Smith (1987), the Chukchi Borderland and Mendeleev Ridge are foundered continental fragments. Crane (1987) also considered the Alpha Ridge to be of continental origin. The tectonic scenario outlined by both models is very similar. The Canada Basin began to open in the Late Jurassic (150 Ma), as the North Slope terrane rifted away from the Alpha Ridge and the Chukotka terrane translated dextrally with respect to the Siberian margin. By the mid-Cretaceous the Chukchi Borderland and Mendeleev Ridge had been stretched and rifted away from the Lomonosov margin. The Canada Basin had finished spreading by $80 \mathrm{Ma}$ (at the latest), and the focus of rifting shifted to the North Atlantic (Lawver \& Scotese, 1990).

There are several problems with such a model (Lawver \& Scotese, 1990). The 


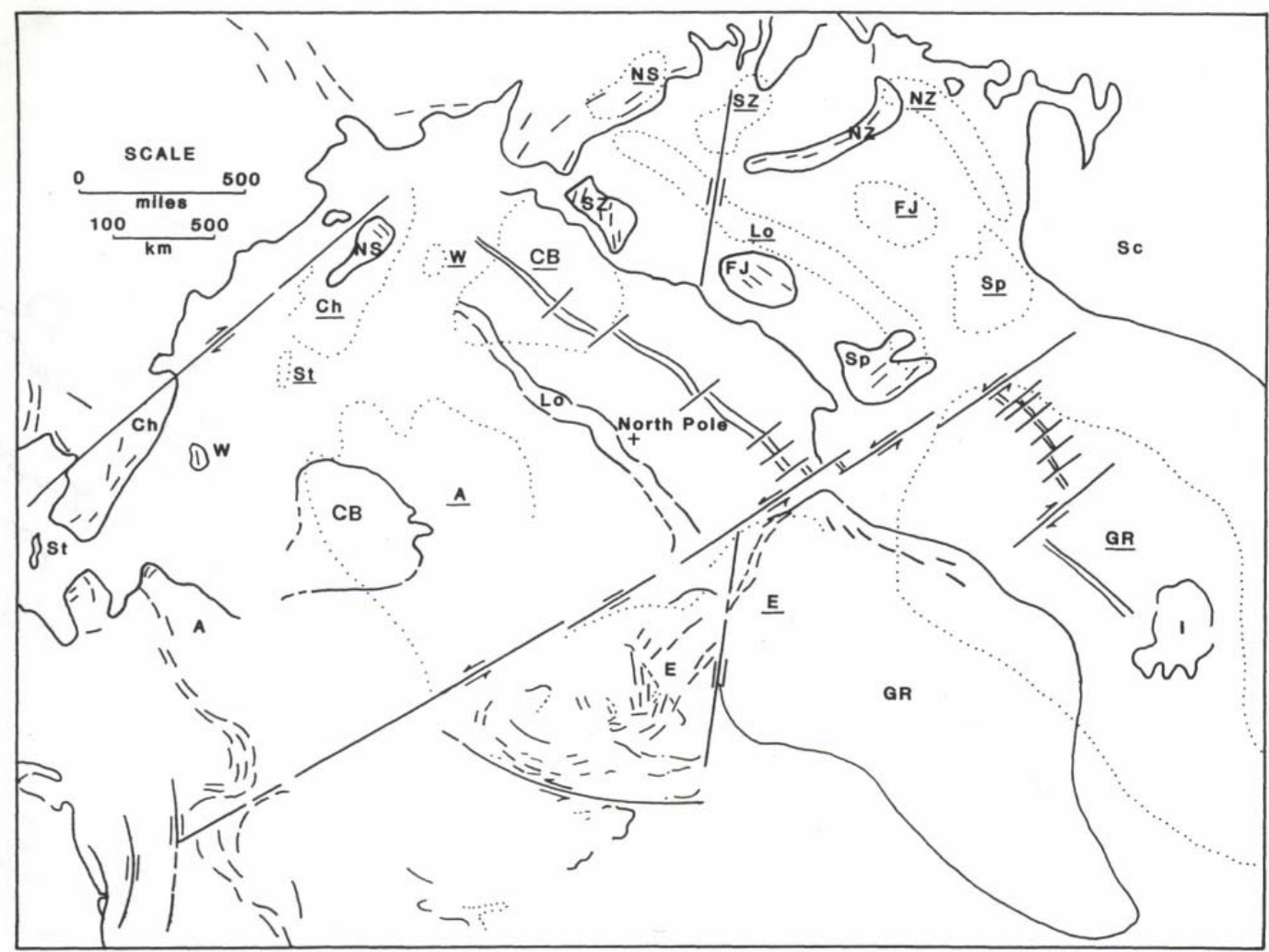

Figure 16 - Figure illustrating the Arctic Islands strike-slip model redrawn from Dutro (1981) and showing the hypothetical development of the Arctic Ocean Basin and adjacent regions in post-Paleozoic time. A, Northern Alaska; Ch, Chukchi Peninsula; CB, Chukchi Borderland; E, Ellesmere Island; FJ, Franz Josef Land; GR, Greenland; I, Iceland; Lo, Lomonosov Ridge; NS, New Siberian Islands; NZ, Novaya Zemlya; Sc, Scandinavia; Sp, Spitsbergen; St, St Lawrence Island; SZ, Severna Zemlya; W, Wrangal Island. Dashed outlines with underlined letters indicate approximate positions during early Mesozoic time. Large arrows show directions of relative transport. Small arrows show relative transcurrent movements (from Lawver \& Scotese, 1990). 

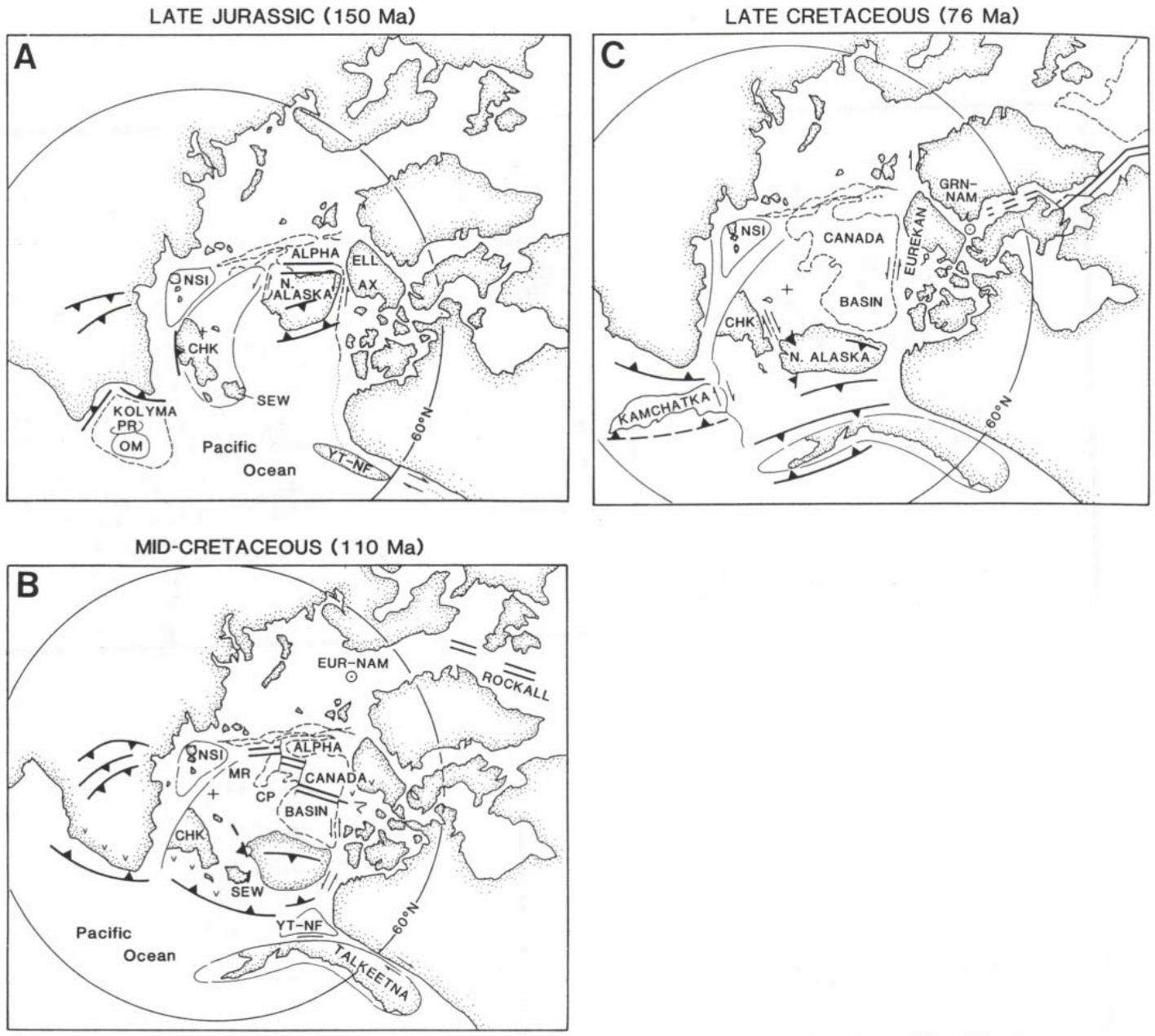

Figures 17 - Figures redrawn from Smith (1987) illustrating a modification of the Arctic Islands strike-slip model. Ax, Axel Heiberg; CHK, Chukotka block; CP, Chukchi Borderland; ELL, Ellesmere; EUR-NAM, pole of opening for Eurasia-North America; MR, Mendeleev Ridge; NSI, New Siberian Islands; OM, Omolon block; PR, Prikolymsk block; YT-NF, Yukon-Koyukok block; SEW, Seward Peninsula. (A) reconstruction of the Canada Basin. (B) mid-Cretaceous reconstruction of the region showing active spreading occurring parallel to the Alpha Ridge. (C) Late Cretaceous reconstruction showing continued motion along strike-slip faults bordering the Canada Basin (from Lawver \& Scotese, 1990) 
most prominent of these is the contention that the Alpha-Mendeleev ridges acted as a spreading centre. Recent bathymetric data shows that the morphology of the ridges is unlike any known spreading centre (Figure 1). Also, recently dredged volcanic rocks from the Alpha ridge were dated as Middle Cretaceous in age, making it unlikely that it is of Paleozoic age as suggested by this model. The current hypothesis is that the AlphaMendeleev ridges are the remnants of a hotspot track, the track of the current Iceland hotspot.

The suggestions by Crane (1987) and Smith (1987) that the Mendeleev and Alpha ridges along with Chukchi borderland are all of continental origin would appear to be erroneous; current thinking (Lawver \& Scotese, 1990) is that only the Chukchi Cap and the Northwind Ridge are of continental origin.

As noted by Embry (1990), the structure and stratigraphy of Northern Alaska continues to the south-east into the Richardson Mountains and links with the North American Cordillera. Creation of the Canada Basin by strike-slip along the Canadian Islands should result in displacement across a fault, which, however, is not observed.

Finally, the Sverdrup Basin, according to the model, formed on the eastern edge of the fault. However, the Sverdrup Basin in terms of its morphology and stratigraphy does not appear to be a strike-slip basin (Morrell et al, 1995).

\subsubsection{Arctic Alaska Strike-Slip Model}

The third subdivision is the Arctic Alaska strike-slip model in which northeastern Siberia or the Chukchi Plateau rift away from the Canadian Arctic Islands (Herron et al, 
1974; Vogt et al, 1982; Metz et al, 1982). In this model the North Slope margin is a transform fault.

This model is the converse of the Arctic Islands Strike-Slip model, the assignment of passive and transform margins has been switched. In the resulting model, the Canadian Arctic is a passive margin, as is the Siberian shelf edge. Consequently, the North Slope margin and Lomonosov Ridge are the transform faults that bounded the basin.

Herron et al. (1974) (Figure 18) proposed that the Kolymski block collided with Arctic Canada during the early Paleozoic (Franklinian orogeny). The same block rifts away during Middle Jurassic (187 to $163 \mathrm{Ma}$ ) with transform motion parallel to Arctic Alaska and the Lomonosov Ridge. The Canada Basin was fully opened when the Kolymski block collided with Siberia along the Verkhoyansk fold belt in Early Cretaceous time. During the period 81 Ma to $63 \mathrm{Ma}$, the pole of opening between North America and Eurasia was in northern Greenland (Lawver \& Scotese, 1990). Herron et al. (1974) assumed that such a pole would necessitate compression north of Greenland and suggested that the compression was accommodated, in part, by subduction along the Alpha and Mendeleev Ridges.

Several more recent models (Vogt et al., 1982; Metz et al., 1982; Rowley et al., 1985) (Figure 19) have suggested that the Chukchi Borderland, rather than the Kolymski block, was the terrane that rifts away from the Arctic Islands. This interpretation is in best agreement with the trend of linear magnetic anomalies in the Canadian Basin (Vogt et al., 1982) and crustal structure inferred from seismic refraction studies (Mair \& Lyons, 1981). Rowley et al. (1985) took this model one step further and argued that the Canada 


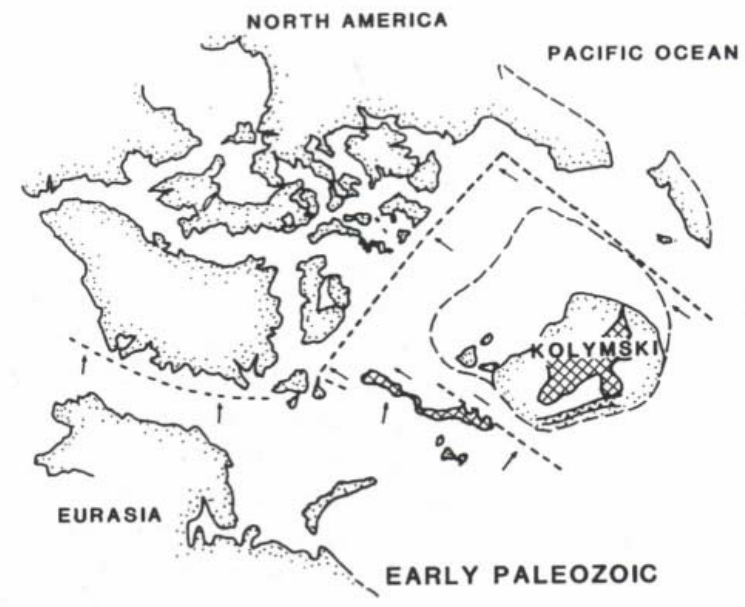

A

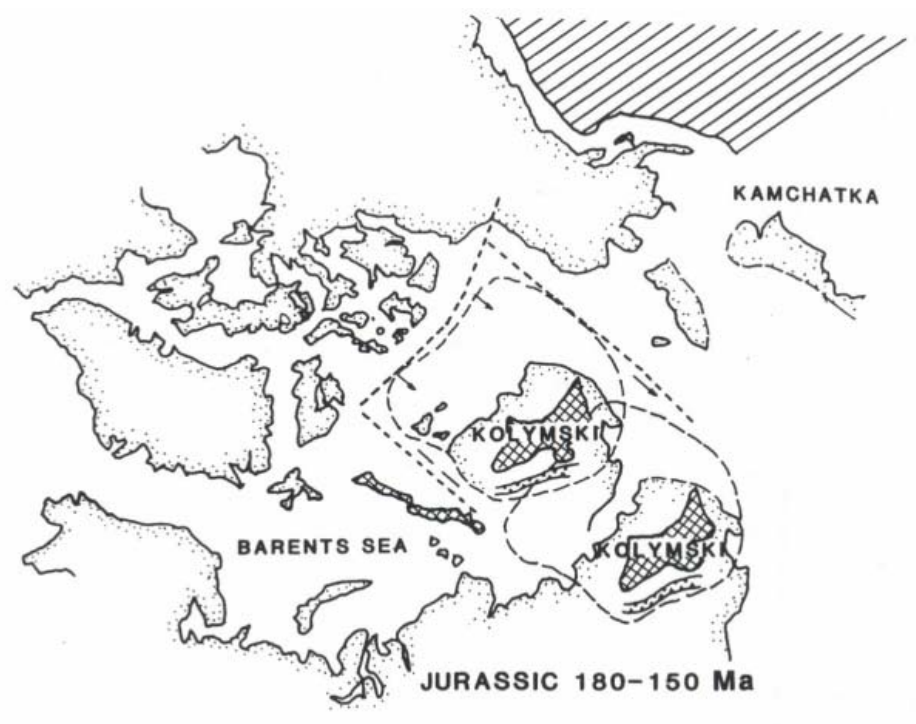

B

Figure 18 - Figure redrawn from Herron et al (1974) showing the North Slope transform model. Heavy dashed lines with arrows show major plate boundaries and direction of movement relative to North America. (A) closure of proto-Amerasia Basin in early Paleozoic time. This motion culminated with mid-Paleozoic folding of Franklinian geoclinal sediments and shedding of clastic rocks onto Canadian Arctic islands, Brooks Range, and Wrangel island north of Chukotka. (B) opening of the Amerasia Basin during Jurassic magnetic quiet period, as Kolymski broke away from North America (from Lawver \& Scotese, 1990). 


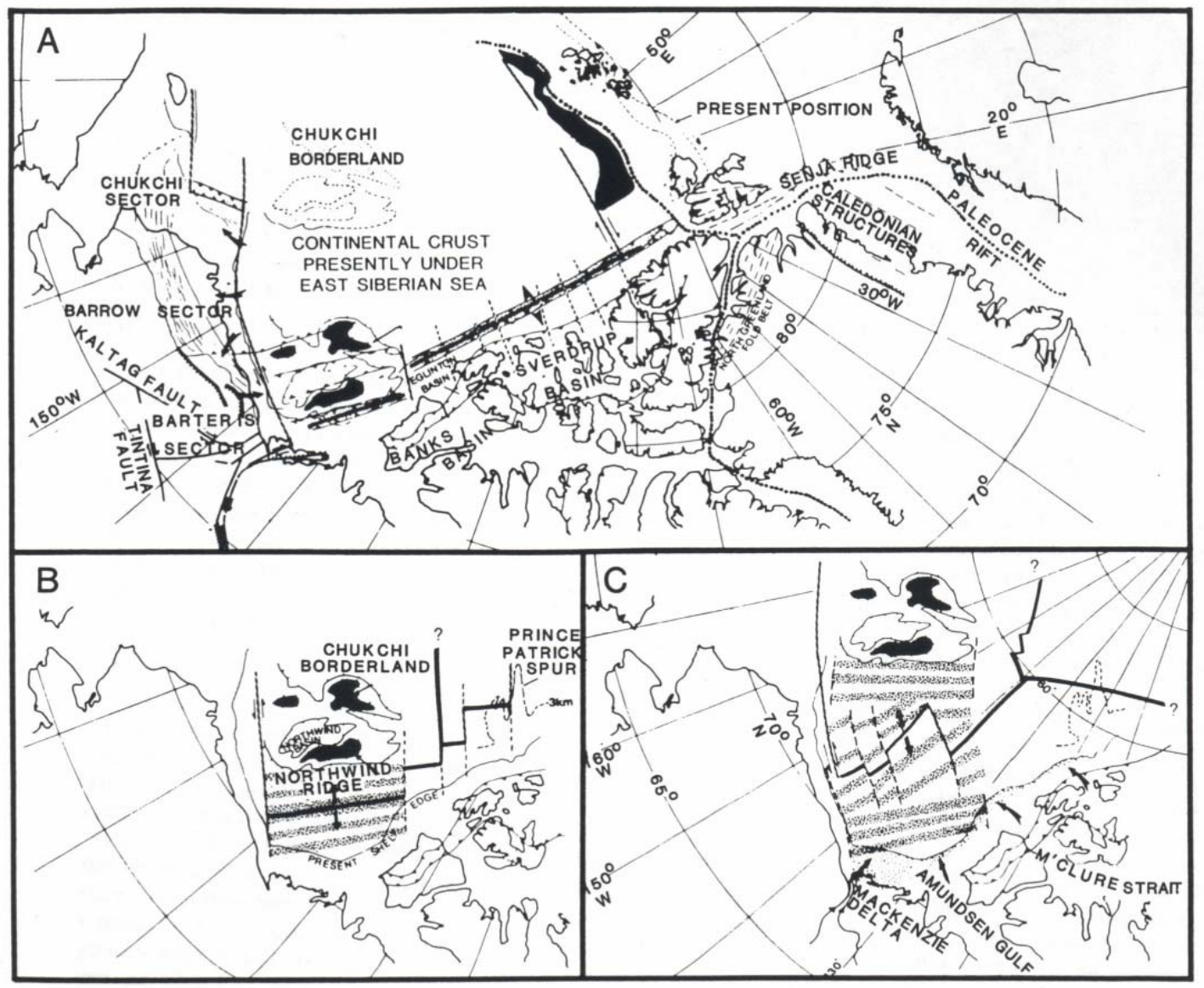

Figure 19 - Modification of North Slope transform model redrawn from Vogt et al (1982). (A) Jurassic to Lower Cretaceous rifting breaks up Chukchi Borderland and detaches it from Kolyma block, which begins to separate from the Canadian Arctic Islands along a line roughly paralleling the Banks-Eglinton-Sverdrup basins. At this time there is still southward sediment transport (arrows) into northern Alaska. (B) the first phase of spreading ends and the plate boundary begins to reorient itself and becomes extinct at time shown in (C) (from Lawver \& Scotese, 1990). 
Basin is, in effect, a back-arc basin that opened as a result of subduction to the west beneath the Alpha and Mendeleev Ridges.

The main argument I have against such a model is that available seismic data of the North Slope margin quite clearly shows that of a passive margin, and not a strike-slip margin; all the observed structures are extensional. Also, the stratigraphy of Arctic north east Russia is not a good stratigraphic match to Arctic Canada; however, because of the large distances across the shelf this may be debatable. This distance may be sufficient to allow the stratigraphy to change markedly.

\subsubsection{Yukon Strike Slip}

Lastly, the fourth model suggested by Jones proposes a combination of trapped Paleozoic oceanic crust, dextral strike-slip movement along the North Slope margin, and sea-floor spreading along the Alpha Ridge (Lawver \& Scotese, 1990) (Figure 9).

Jones assumed that much of the crust in the Canada Basin is Paleozoic in age and was attached to Arctic Canada as part of the North American plate. The North Slope of Alaska and northeast Siberia formed a single terrane and were offset with respect to North America by a large right-lateral strike-slip fault that aligned the Tintina fault, the margin of the North Slope, and the Arctic margin of northeastern Siberia.

During the Permo-Triassic the North Slope terrane translated northward (rightlateral motion) with respect to North America along this mega-fault zone. Strike-slip motion continued, and during the Early Cretaceous the Makarov and northernmost half of the Canada Basin opened as Alaska continued to translate northward. During the Late Cretaceous and early Tertiary, extension in the North Atlantic resulted in compression in 
Alaska, and the North Slope/northeastern Siberian block moved northeastward with respect to cratonic North America along a dextral strike-slip fault that ran along the Katlag fault and the margin of the Canadian Arctic Islands (Lawver \& Scotese, 1990).

There are several problems with such a model, previously discussed as evidence against the previous two insitu models, the Yukon Strike Slip and Arctic Alaska strikeslip models. Firstly, Jones suggested that much of the crust in the Canada Basin was Paleozoic in age and attached to Arctic Canada, suggesting a continental origin, which is debatable. As mentioned earlier the Chukchi Cap and the Northwind Ridge appear to be the only continental rock present in the Canada Basin. Also, the Alpha ridge was suggested (Herron et al, 1974; Vogt et al, 1982; Metz et al, 1982) to be a spreading center in the Arctic Islands Strike-Slip model, but this ridge appears more likely to be a hotspot track than a spreading center (Lawver \& Scotese, 1990). Also, as with the both strikeslip models, the North Slope basin and the Canadian Island margins would appear to be a passive margin rather than a strike-slip. 


\section{Chapter 4: Geophysics \& Sea-Floor Spreading}

\subsection{Gravity}

The gravity data of the Canada Basin (Figure 20) shows a gravity low which has been interpreted as a fossil spreading center located where it is predicted by the rotation model (Laxon \& McAdoo, 1998). It is interesting that the gravity low trends essentially north-south in the northern Canada Basin, but it bends about $30^{\circ}$ as it approaches the MacKenzie delta (Figure 20). This suggests the geometry of the rotational opening is somewhat more complicated than what was originally proposed by Grantz et al (1979).

\subsection{Magnetic Anomalies}

Positive magnetic anomalies are places where the magnetic field is stronger than expected, induced when the rock cools and solidifies with the Earth's north magnetic pole in the northern geographic hemisphere.

The Earth's magnetic field is thus enhanced by the magnetic field of the rock. Negative magnetic anomalies are magnetic anomalies that are weaker than expected, induced when the rock cools and solidifies with the Earth's north magnetic pole in the southern geographic hemisphere. The resultant magnetic field is less than expected because the Earth's magnetic field is reduced by the magnetic field of the rock.

A most significant magnetic anomaly map was constructed based on detailed surveys off the western seaboard of North America (Mason \& Raff, 1961; Raff \& Mason, 1961; from Kearey \& Vine, 1996). The pattern was anything but uniform, and revealed an unexpected pattern of stripes defined by steep gradients separating linear regions of high amplitude positive and negative anomalies. 
The magnetic anomaly data for the Canada Basin (Figure 21) appears to show two sets of very different magnetic anomalies. North of $80^{\circ} \mathrm{N}$ there are very strong anomalies with an irregular pattern similar to the skin of a leopard. This pattern extends over the area of the Alpha-Mendeleev ridge and has been attributed to hotspot volcanism (Lawver \& Scotese, 1990). South of $80^{0} \mathrm{~N}$ the magnetic anomalies are relatively weak lineaments that mirror each other on both sides of the observed gravity anomaly through the centre of the basin. These magnetic anomalies have a general westnorthwest-eastsoutheast trend, and are also slightly curved, just like the gravity anomaly. The strength of these anomalies has been attributed to the unusually thick sedimentary cover in the Canada Basin, sometimes up to $12 \mathrm{~km}$ in thickness (Grantz et al, 1987). Another important inference can be made from the presence of these magnetic anomalies for the timing of rotational opening of the basin. Due to the presence of these magnetic anomalies it can be inferred that the Arctic Alaskan plate was rotating away from the Canadian Arctic Islands after the Lower Cretaceous unconformity and prior to the Cretaceous long normal magnetic stage, which would place the date of the basin's opening between 135-118Mya (Ogg, 1995).

The presence and alignment of the gravity and magnetic anomalies does not appear to fit with the Arctic Islands Strike-Slip model or the Yukon Strike-Slip model. In both of these models, if any sea-floor spreading was occurring, the gravity and magnetic anomalies would most likely be seen to trend parallel to the Lomonosov Ridge, at 90 degrees to what is observed in the central Canada Basin. It may, however, be possible to explain their presence by either the rotational or Arctic Alaska Strike-Slip models. 


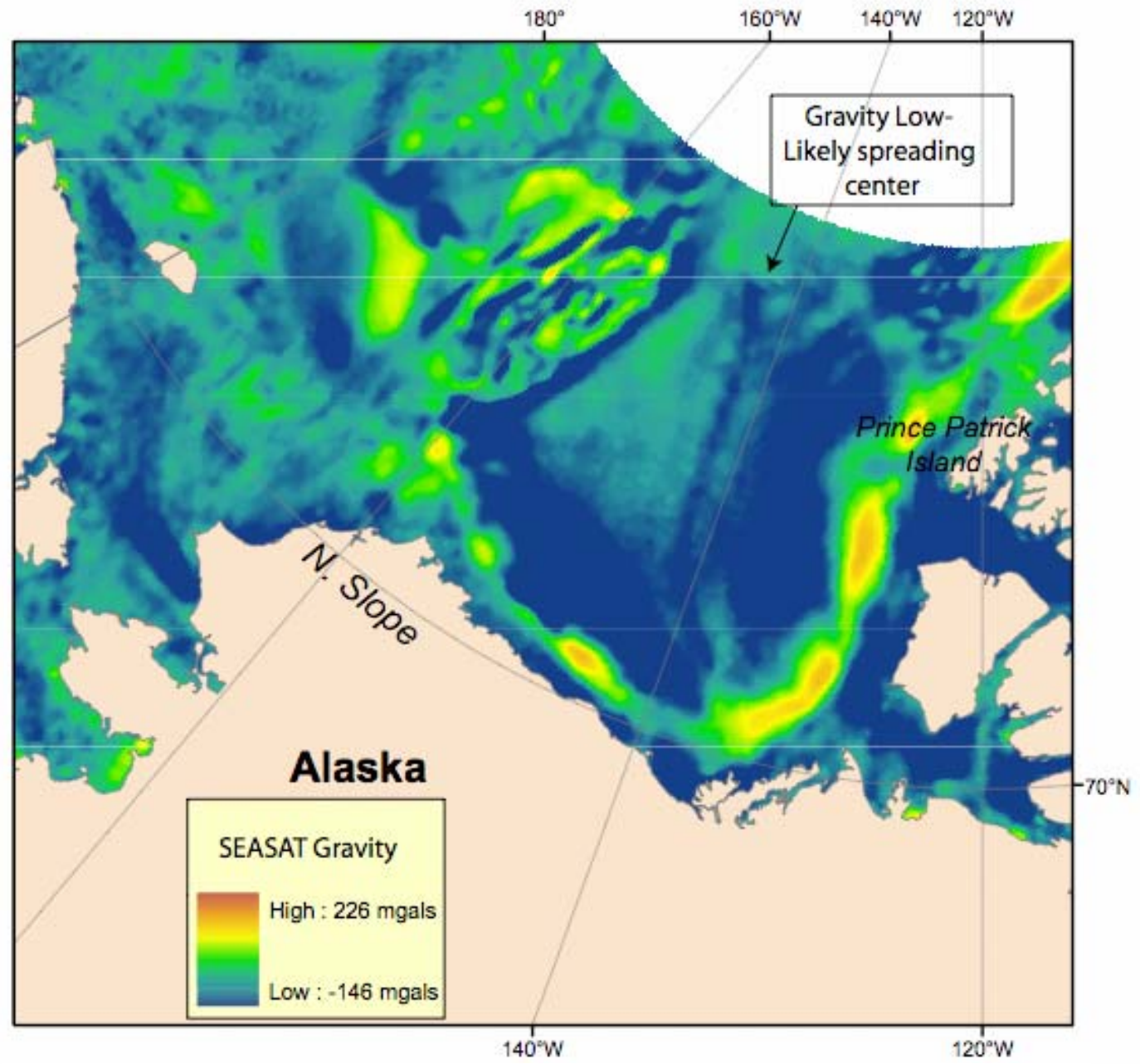

Figure 20 - Gravity anomaly map of the Canada Basin (Laxon \& McAdoo, 1998). 


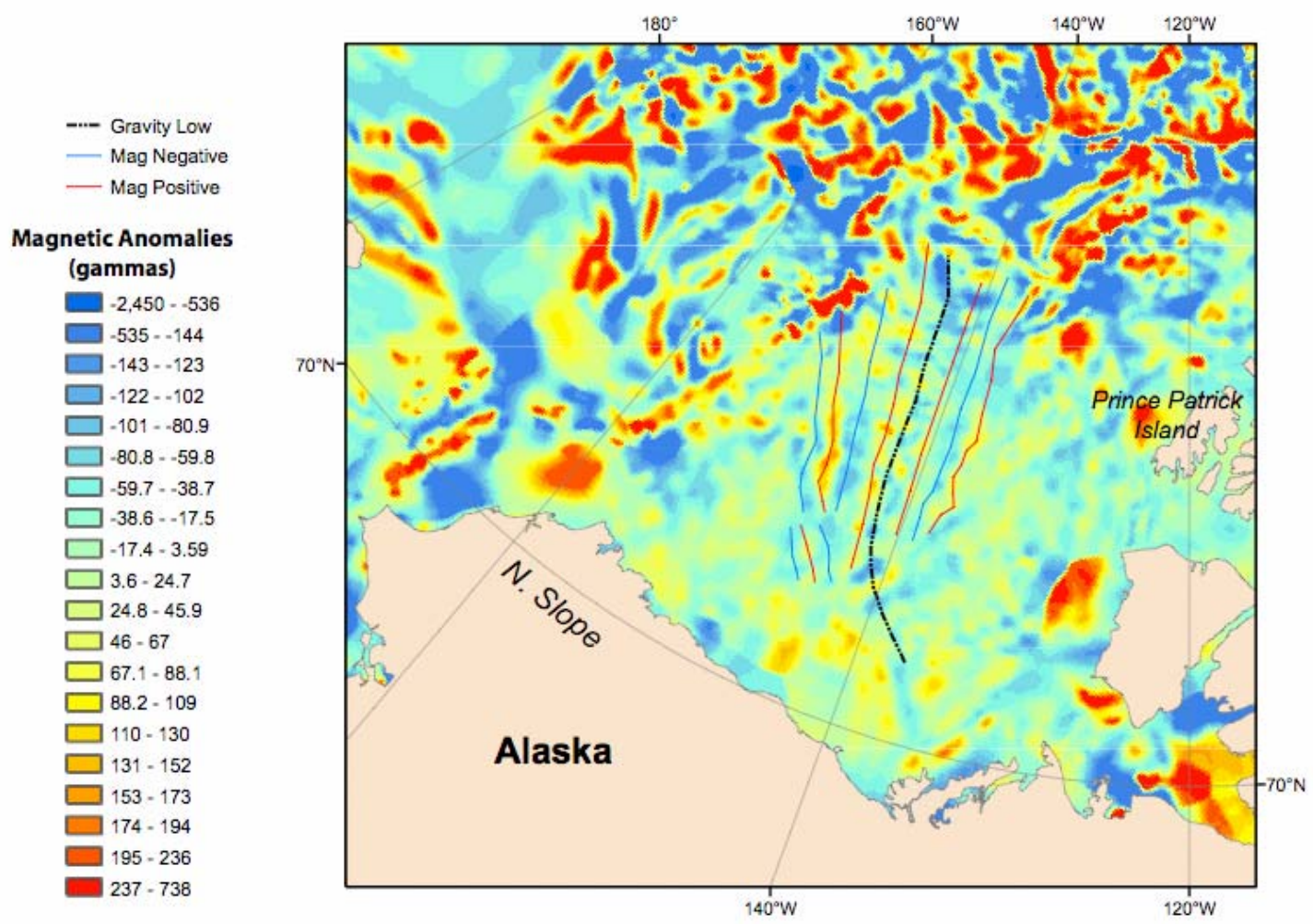

Figure 21 - Magnetic anomaly map of the Canada Basin. The gravity low in the centre of the Canada Basin is the likely spreading center, with positive and negative magnetic highs being mirrored on both sides of this low (Verhoef et al, 1996). 


\section{Chapter 5: Data}

\subsection{Well Data}

Well log data including gamma ray, density and neutron wire-line data for the North Slope and adjacent shelf areas is available through the public domain. From 1944 to 1953 the U.S. Navy operated a large-scale exploration of the then Naval Petroleum Reserve No. 4, drilling 36 test wells and 45 core tests (Figure 22). A second extensive exploration program was operated between 1974 and 1982. Run first by the U.S. Navy and later the USGS, this exploration program drilled an additional 28 exploratory wells (Figure 22). Of these, only 73 wells containing wire-line logs were actively imported into the interpretation. The USGS identified several formations in the well core data which form the basis (along with onland outcrops) for Moore’s (1994) and Embry’s (1989) stratigraphic columns (Figures 4 \& 5 respectively). The most notable of these, the Franklinian metamorphics, Endicott Group, Lisburne Limestone Group, Sadlerochit Group, Sadlerochit Group, Sag River sandstone, Shublik Formation, Kingak Shale, Pebble Shale Unit and the Torok Formation are the most common subdivisions of the well cores (Bird, 1988) and thus used as a basis for the subdivision of rock units in this research. This data is available online from the U.S. Geological Survey National Petroleum Reserve, Alaska (Legacy Data Archive; Bird, 1988).

\subsection{Seismic Data}

Three sets of seismic data were used in this paper. Two public domain sets of multichannel seismic lines have been published by USGS (Agena et al, 2000, 2001), the first, consists of stacked and migrated multi-channel seismic-reflection data for 65 lines 
(roughly 2473 miles) recorded in the Beaufort Sea by the United States geological Survey in 1977 (Figure 23) of which 18 were deemed useful to the study area. Examples of seismic lines shown in Figures 24 and 25.

The recording system used was a Globe Universal Sciences (GUS) model 4200 recording 24 channels at a 2-millisecond sample rate. A tuned array of five air-guns totaling 1326 cubic inches was used as the seismic energy source and was fired at 50meter intervals. The receiver array consisted of 24 groups of hydrophones spaced at 100meter intervals for a total array length of 2400 meters. Recording lengths varied between 6 and 7 seconds sub-seafloor with deep-water recording delays implemented over the continental slope and rise. Positioning of the survey was achieved using a Marconi integrated satellite-doppler sonar navigation system (Agena et al., 2000). The original data was reprocessed by Agena et al (2000) in 2000 using the ProMAX processing system. Standard corrections, such as static corrections, deconvolution, NMO correction, trace weighting, and stacking, were used to increase resolution (Agena et al., 2000).

The second public domain data set (Figure 23) consists of stacked and migrated multi-channel seismic-reflection data for 44 lines totaling several thousand miles of survey lines recorded in the Chukchi Sea, northern Alaska, by the United States Geological Survey in 1977, 1978, and 1980. Of these 44 lines, only 11 were deemed useful to this study. The recording system used was a Globe Universal Sciences (GUS) ${ }^{\circledR}$ model 4200, recording 24 channels at a 2-millisecond sample rate. A tuned array of five air-guns totaling 1326 cubic inches was used as the seismic energy source and was fired at 50-meter intervals. The receiver array consisted of 24 groups of hydrophones spaced at 


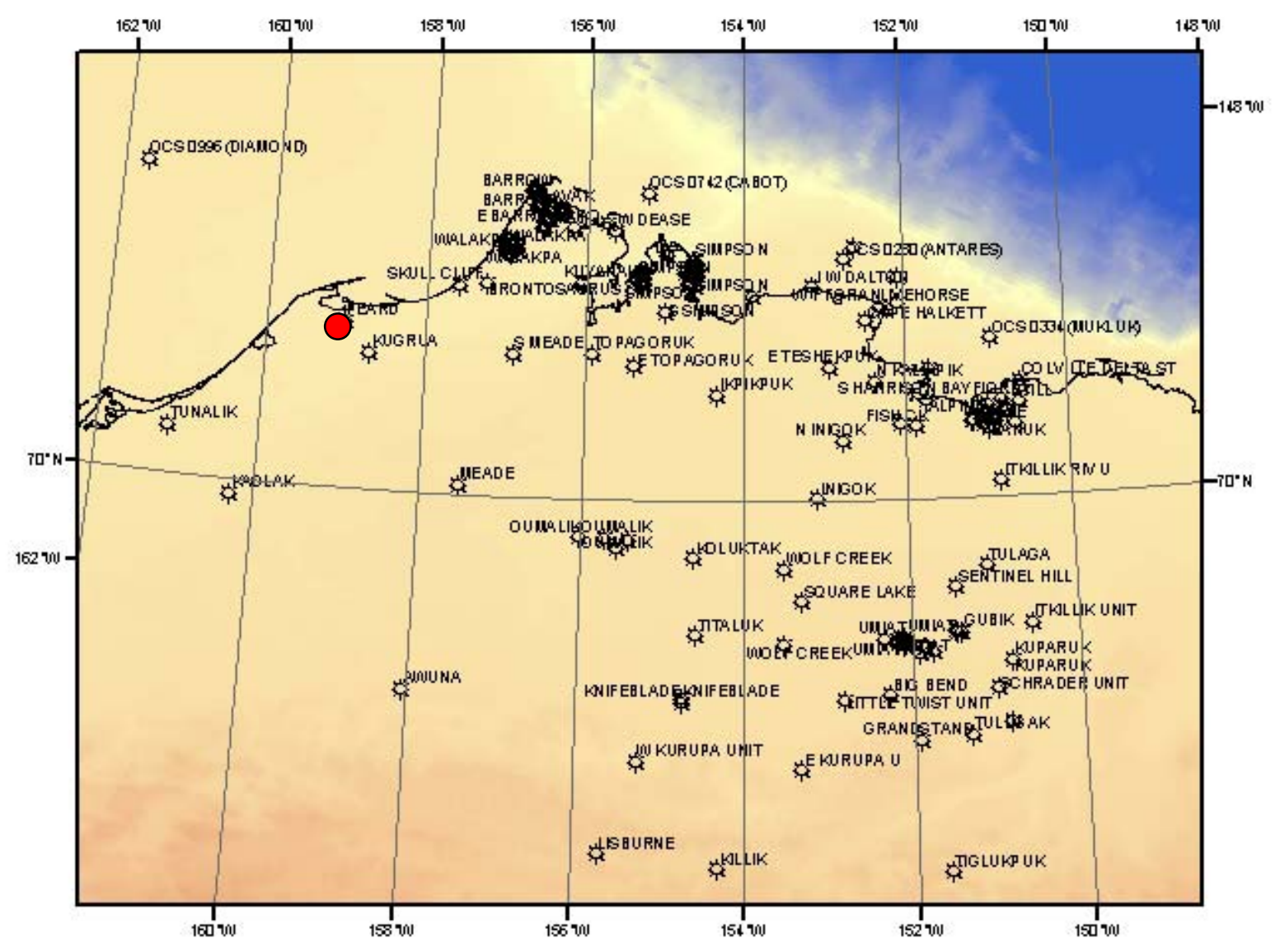

Figure 22 - Map of the North Slope of Alaska showing well locations in target area. Marked red well is the Peard Well. 


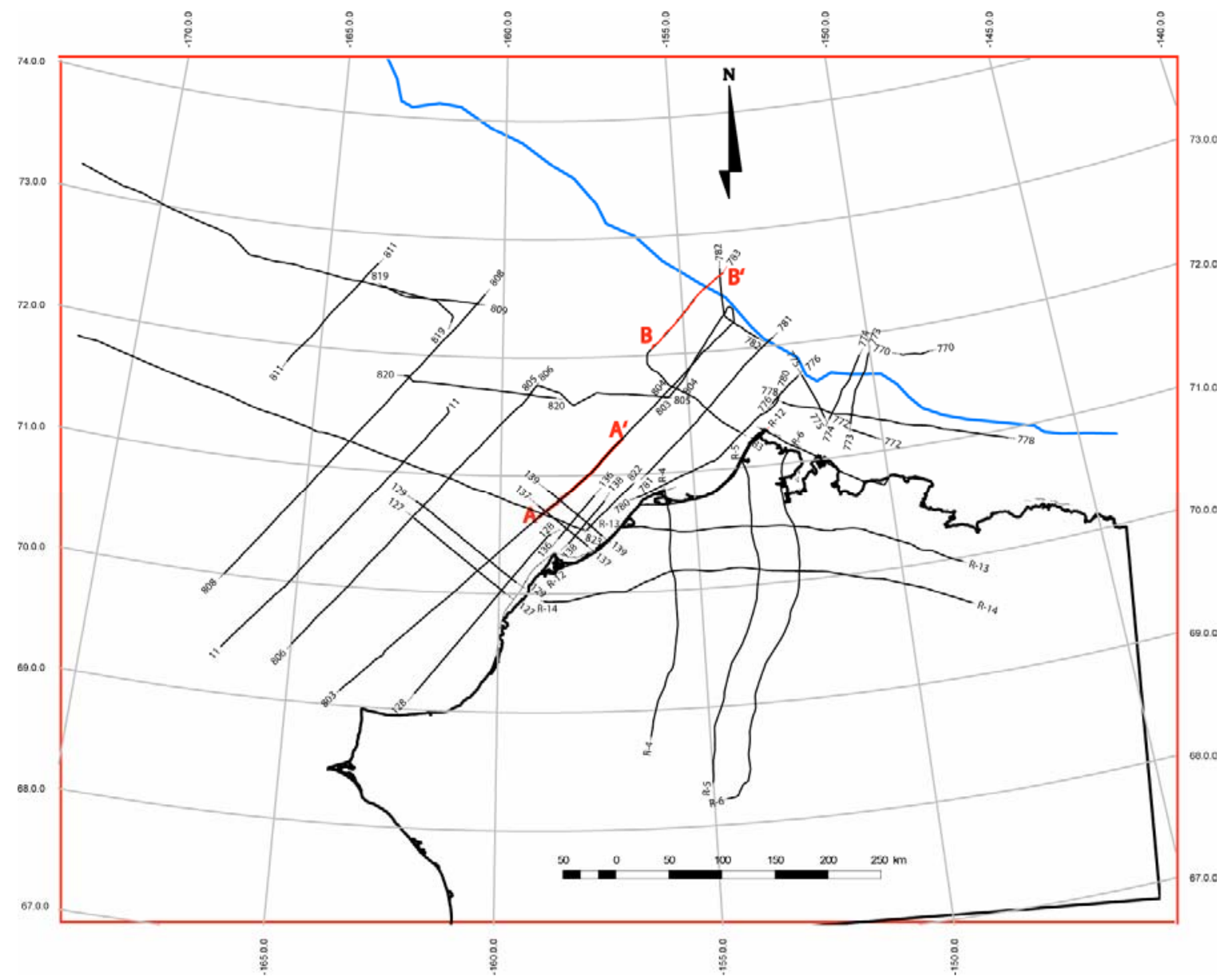

Figure 23 - Map of the North Slope of Alaska showing the location of seismic lines used in the thesis. Line R-12 (A-A') corresponds to Figure 24, and line 783-1 (B-B') corresponds to Figure 25. 
A

C-CWne+18Bes-1137 W-WCS-139

$A^{\prime}$

CMP $\quad 50 \overline{14} 5 \overline{124} 5234533454445554565457645874597460846194629464046514661467246834693470447154$ CMP Shot9405040 51505260536054705580568057905900600061106220632064306540664067506860696070707180 Shot

0.50

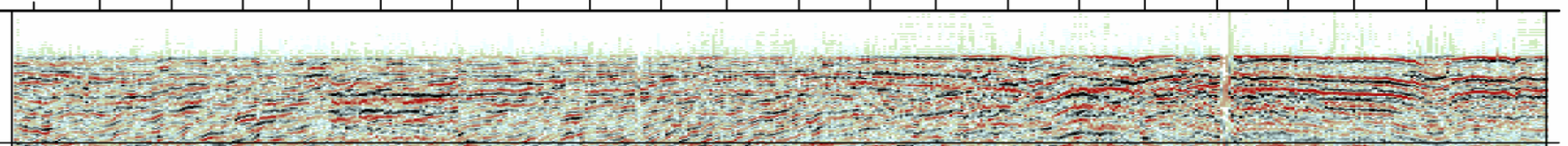

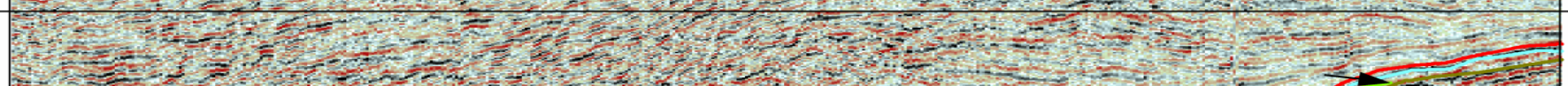

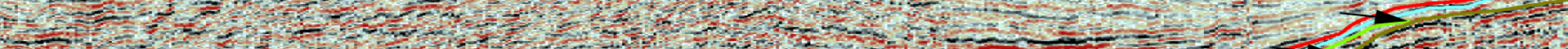

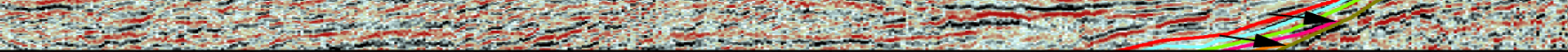

1.00

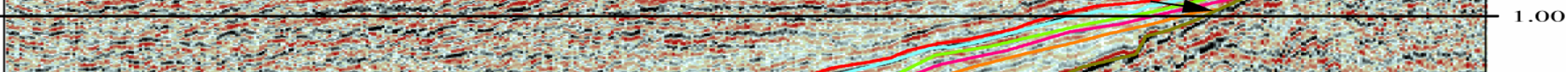

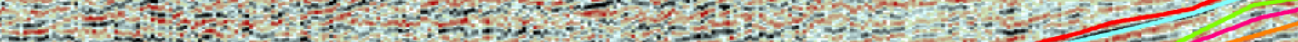

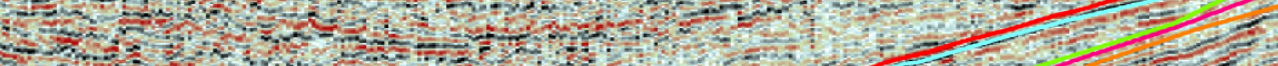

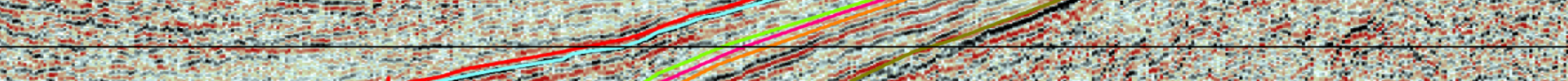

1.50

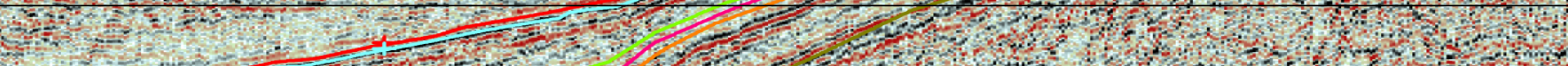

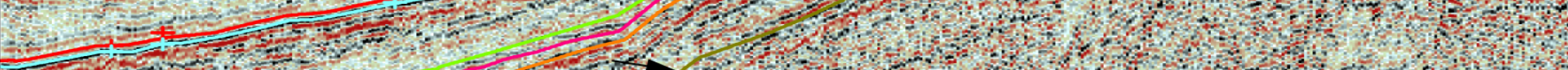

2.00

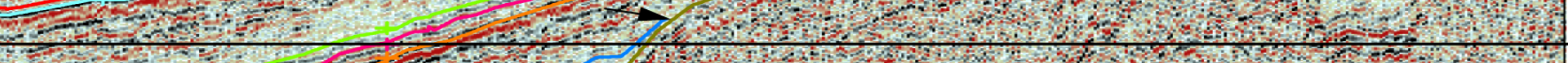

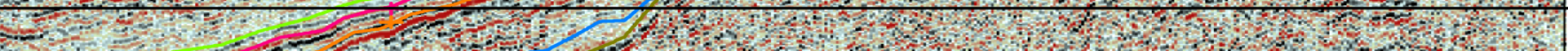

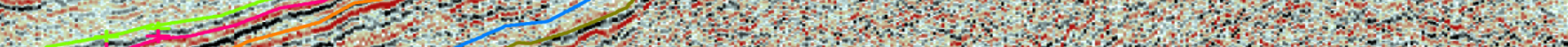

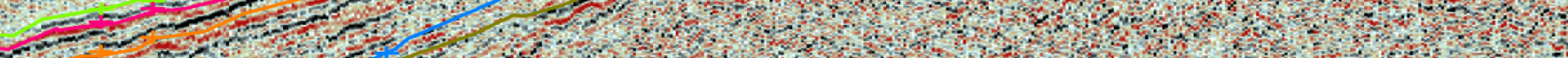

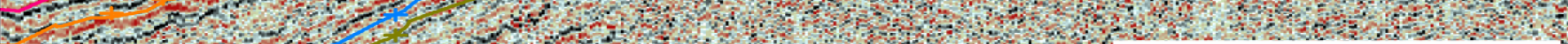

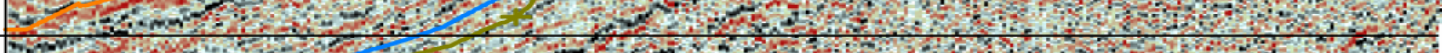

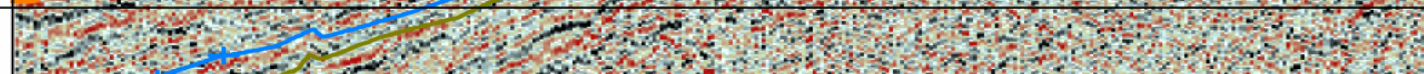

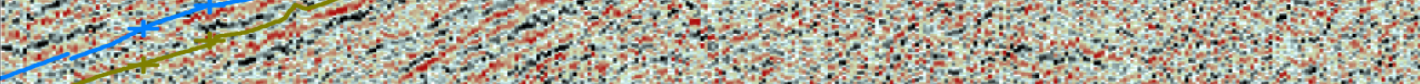

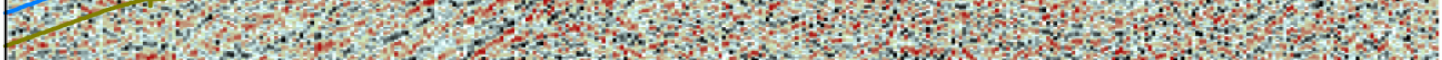

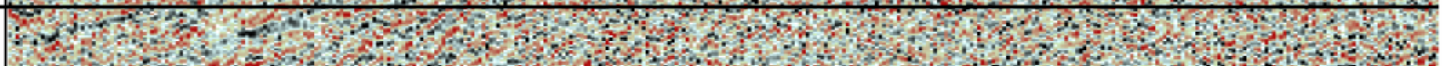

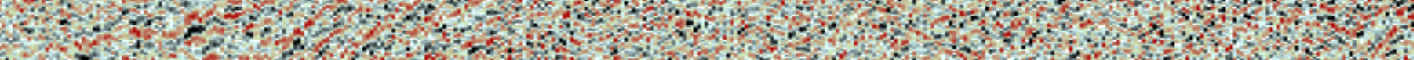

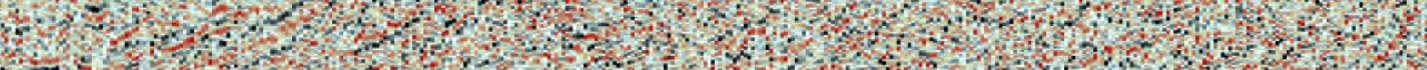

$\longrightarrow \quad \begin{aligned} & \text { Pebble Shale } \\ & \text { Kingak Shale }\end{aligned}$

Kingak Shale

- Shublik Fm.

Sadlerochit Group

Lisburne Group

Figure 24 - Seismic line 803 showing the Ellesmerian strata onlapping onto the Barrow Arch. 
CMP

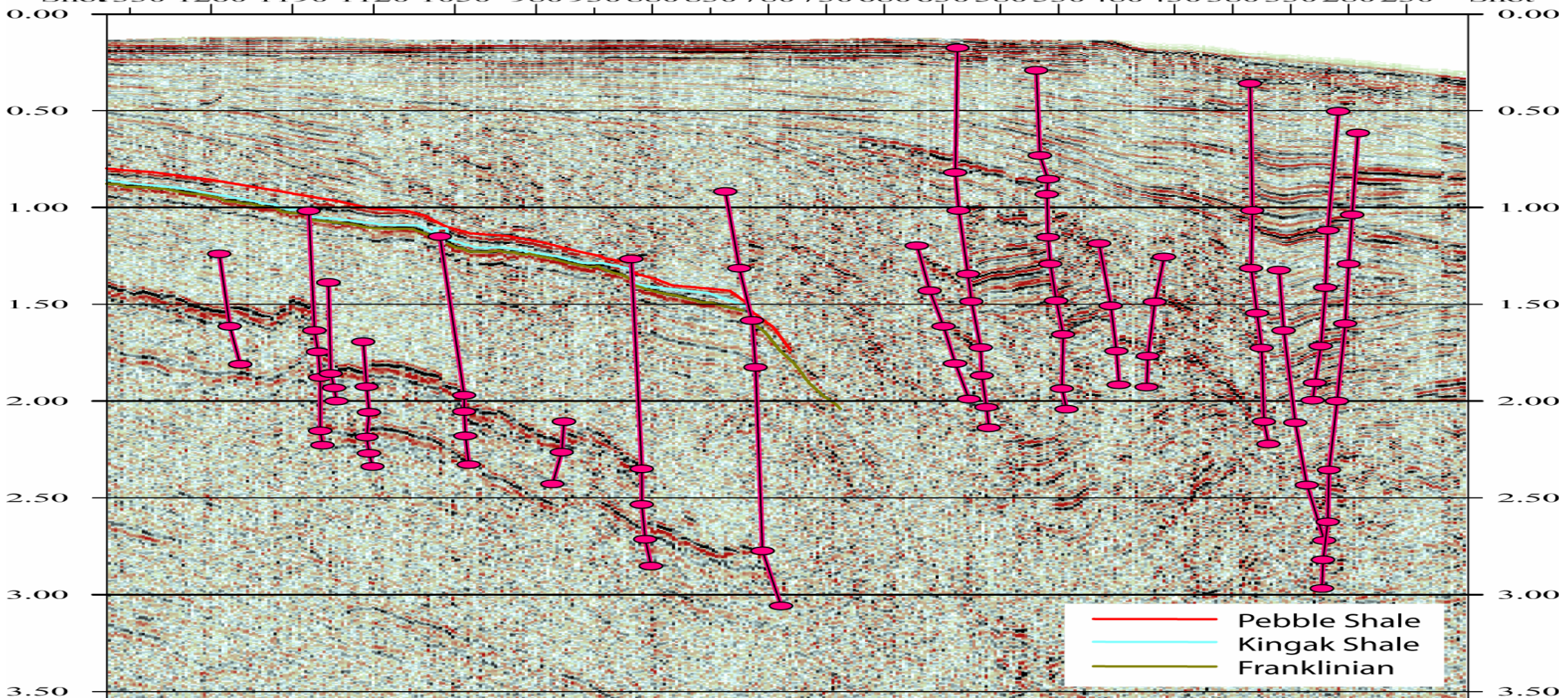

Figure 25 - Seismic line 783, showing the heavily faulted nature of the shelf edge. The Basement, Pebble Shale and Kingak Shale would appear to dip off the base of the seismic line around shotpoint 600 to the north. 
100-meter intervals, for a total array length of 2400 meters (Agena et al., 2001). The original data was reprocessed in 2000 by Agena et al using the ProMAX processing system. Standard corrections, such as static corrections, deconvolution, NMO correction, trace weighting, and stacking, were used to increase resolution (Agena et al., 2001).

A third set of proprietary data collected by Western-Geco in the Beaufort and Chukchi seas has recently been made available to the public (NAMSS, 2004). It consists of several thousands miles of stacked and migrated multi-channel seismic data recorded by Western-Geco in 1970-1971 (NAMSS, 2004). After extensively looking through this data, 6 seismic lines from Western-Geco were used in this study.

The quality of the seismic data in some parts of the study area was of extremely poor resolution making correlation very difficult. Also, the coverage of the seismic data was not ideal for the problem that that this research was attempting to resolve, with several parts of the study area with inadequate data to construct accurate Isochore maps of the Ellesmerian strata. 


\section{Chapter 6: Interpretation/Results}

\subsection{Seismic/Well interpretation \& results}

To begin with, the seismic and well data were loaded into Landmark Geographix software package. From examing wire-line and the core-log data acquired from the NPRA wells database (Figure 26, showing example well wire-line log), it was decided to interpret 8 main horizons; Franklinian sequence (Devonian \& older), Endicott Group (Mississippian), Lisburne Group (Pennsylvanian), Sadlerochit Group (Upper Permian Lower Triassic), Shublik Formation (Upper Triassic), Sag River Formation (Upper Triassic), Kingak Shale (Jurassic - Lower Cretaceous) and the Pebble Shale Unit (Lower Cretaceous). The Endicott Group, Lisburne Group, Sadlerochit Group, Shublik Formation and Sag River Formation form the Ellesmerian Sequence (Mississippian Lower Cretaceous), which represent the Pre-rift Strata. The Kingak Shale and the Pebble Shale Unit are part of the Beaufortian Sequence that represent the syn-rift stage of the basin.

On loading the data, the core and wire-line data were examined first in Geographix Well Editor, picking out the eight horizons that had been selected for correlation. The purpose, to construct depth map for the Franklinian Sequence along with isopach maps for the 7 younger formations. Using picks from the core-data and wire-line logs it was possible to tie this information to the seismic lines, in an attempt to identify the defined horizons. This was achieved by converting the core depth to twoway travel time (TWT) in Well Editor. Each well had a velocity log attached to it, which allowed for easy conversion. The well picks were then transferred to the appropriate TWT depth on the seismic lines. Each of the horizons were then traced across the 


\begin{tabular}{|c|c|c|c|c|c|c|c|c|c|}
\hline & Correlatior & & Depth & & Resistivity & & \multicolumn{3}{|c|}{ Porosity } \\
\hline & GR & & \multirow[t]{2}{*}{$\mathrm{MD}$} & \multicolumn{3}{|c|}{$\operatorname{ResS(LL8)}$} & \multicolumn{3}{|c|}{$\mathrm{PH} \| \mathrm{N}(\mathrm{NPH})$} \\
\hline b & GAPI & 150 & & 0.2 & $\mathrm{OHMM}$ & 2000 & 0.45 & $V N$ & -0.15 \\
\hline \multicolumn{3}{|c|}{ SP } & & \multicolumn{3}{|c|}{ ResM(ILM) } & \multicolumn{3}{|c|}{$\mathrm{RHOB}$} \\
\hline-100 & MV & 50 & & 0.2 & $\mathrm{OHMM}$ & 2000 & 2.0 & Gic3 & 3.0 \\
\hline \multicolumn{3}{|c|}{ CALI } & & \multicolumn{3}{|c|}{ ResD(ILD) } & \multicolumn{3}{|c|}{ DT } \\
\hline 5 & $\mathbb{N}$ & 16 & & 0.2 & $\mathrm{OHMM}$ & 2000 & 140 & USIF & 40 \\
\hline
\end{tabular}

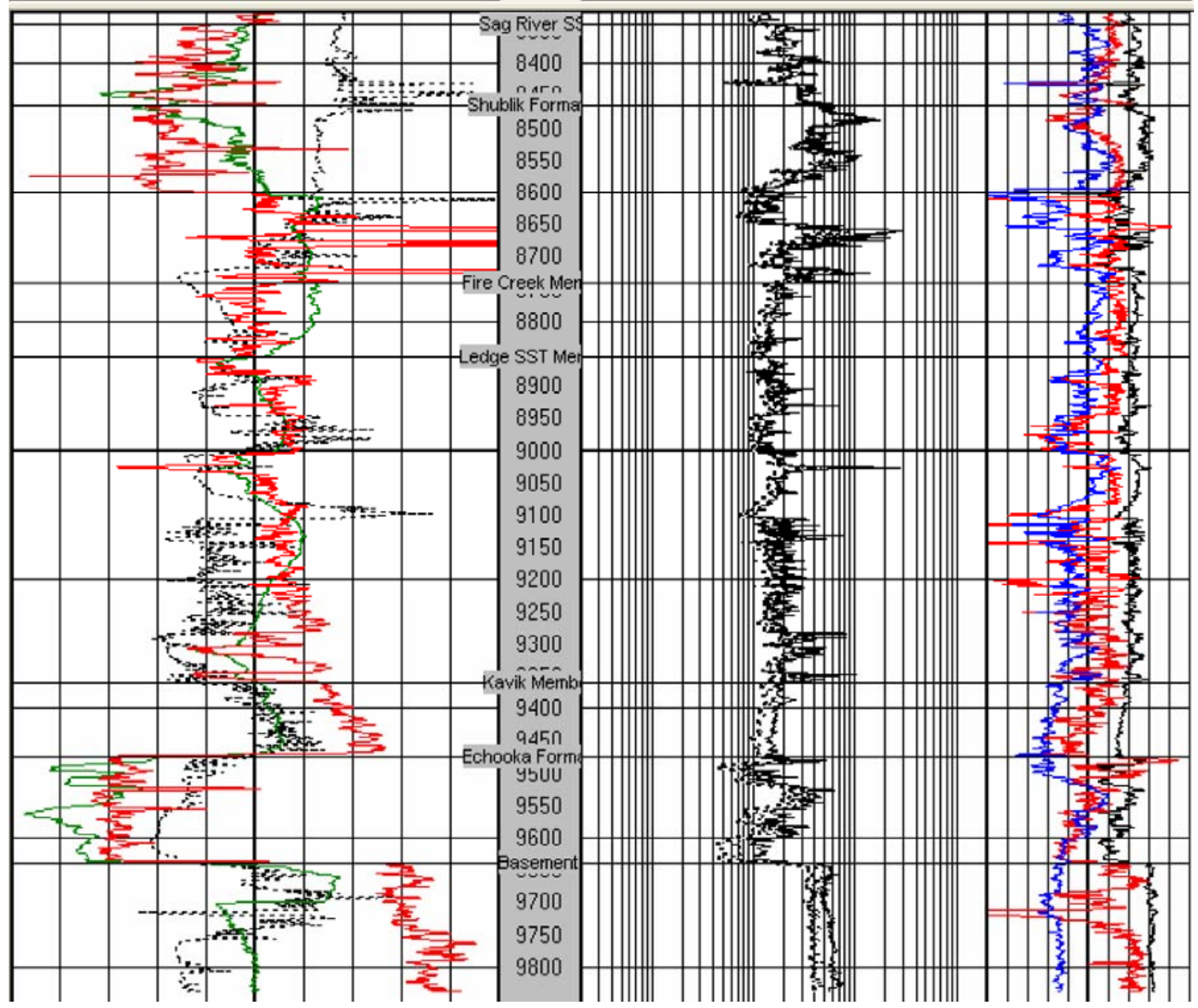

Figure 26 - Wire-line log for the Peard well, showing an interval from the Franklinian Basement up to the Sag River Sandstone. 
seismic lines in a closed-loop to ensure accuracy of picks, with the onshore lines interpreted first due to the onshore well control, before the interpretation was continues offshore, first to the north, then west into the Chukchi Sea.

Using the completed seismic interpretation, it was possible to make a map of the depth (in TWT) to the top of the basement across the study area in Landmark GeoAtlas. Using this seismic basemap, it was then possible to create Isopach maps for each of the Ellesmerian horizons, by subtracting the depth (in TWT) of the each of the Ellesmerian and Beaufortian Horizons away from the depth (in TWT) of the Franklinian Sequence. These isochore maps quite distinctly show the zero or onlap edge of each of the Ellesmerian strata onto the basement rocks.

The seismic interpretation of the basement (Figure 26) clearly shows a high (Barrow Arch) trends from the south-east, along the coastline of Northern Alaska, to the north-west, terminating just offshore. To the north of the Barrow Arch, the basement strata appear to drop off steeply and disappear below the recording depth of the seismic lines well before the edge of the continental shelf. To the south, the basement is interpreted as gradually increasing in depth to about a subsurface TWT of around 5 secs at the south of the study area. In the western part of the study area, in what is known as the Chukchi Sea, the interpretation of the basement appears to show a north-south trending low (Hanna trough), which runs from just offshore Point Lay, due north for about 200 miles due west of Barrow. The Hanna trough is bounded by another high, the Chukchi High, which parallels it to the west.

On isopach maps of the Ellesmerian strata, the zero (or onlap) edge of these various strata can be clearly seen to onlap onto the basement rocks. 


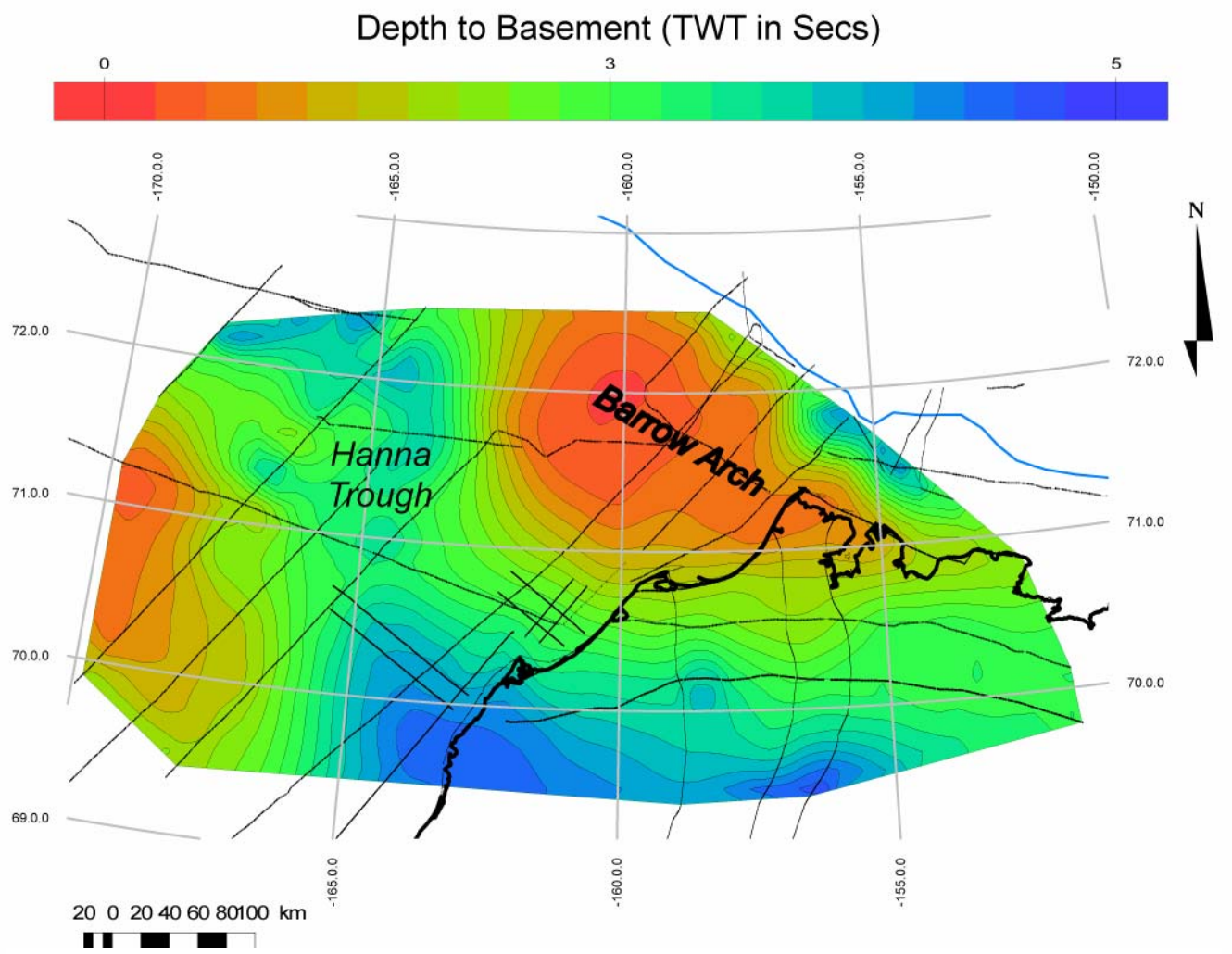

Figure 27 - Contour map showing the depth to the top of the basement in TWT. 
The oldest of the Ellesmerian strata, the Mississippian Endicott Group (Figure 28), onlaps the basement with a general east-west trend across the southern section of the study area, from Icy Cape on the western coast, eastwards to Anaktuk where a depression in the basement creates a small lobe of the Endicott Group which extends further north. From this northward incursion, the Endicott Group continues to onlap along north-east trend to Harrison Bay. The Endicott Group thickens towards the south-east in the eastern part of the study area, and to the south, in the central and western regions of the study area.

The Pennsylvanian Lisburne Group (Figure 29), onlaps the basement generally in a wavy manner from east to west before turning northward along the eastern margin of the Hanna Trough. In the east, it runs along the shoreline, about 20 miles northwards offshore before cutting south-west, coming onshore in the center of Smith Bay cutting east, north of Alaktak. It crosses north-west across Admiralty Bay before turning west and cutting back and forth, across the coastline as it extends to the south-west. About 20 miles south-west of Wainwright it heads north, offshore, bending west around 100 miles offshore before turning north again along the eastern side of the Hanna Trough. The Lisburne Group in a general sense thickens to the south across the North Slope, and to the west in the Hanna Trough.

The Sadlerochit Group (Figure 30) trends almost directly east-west across Dease Inlet, south of Barrow and offshore to the west. Around 140 miles north of Wainwright the onlap edge begins to head to the north-west, before turning northwards, due north of Icy Cape. As with the Lisburne Group, the Sadlerochit Group generally thickens to the south across the onshore North Slope, and to the west in the Hanna Trough, in the 


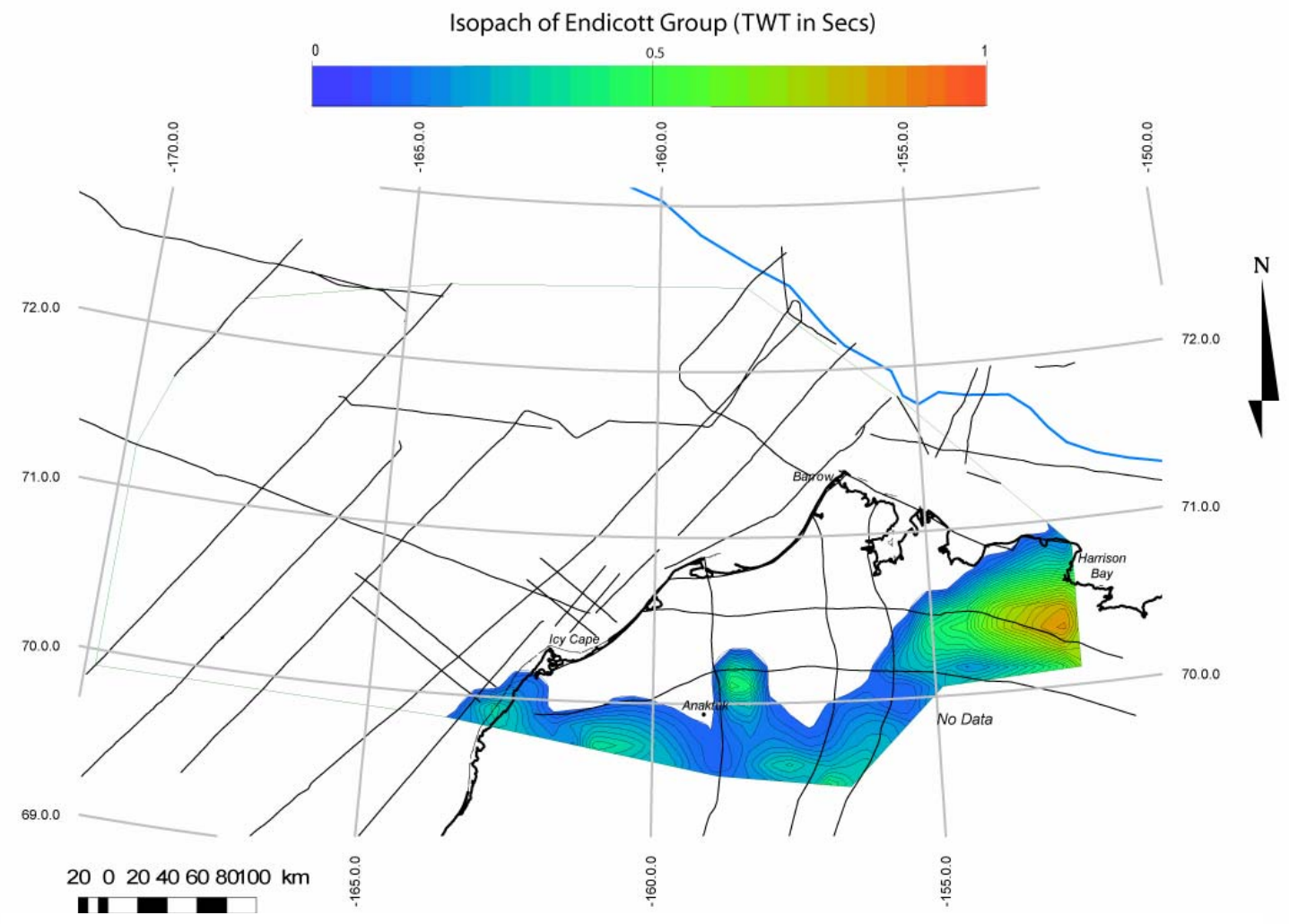

Figure 28 - Contour map showing the thickness from the top of the Endicott Group to the basement, in TWT. The map also, clearly shows the zero or onlap edge of the Endicott Group onlapping onto the basement. 


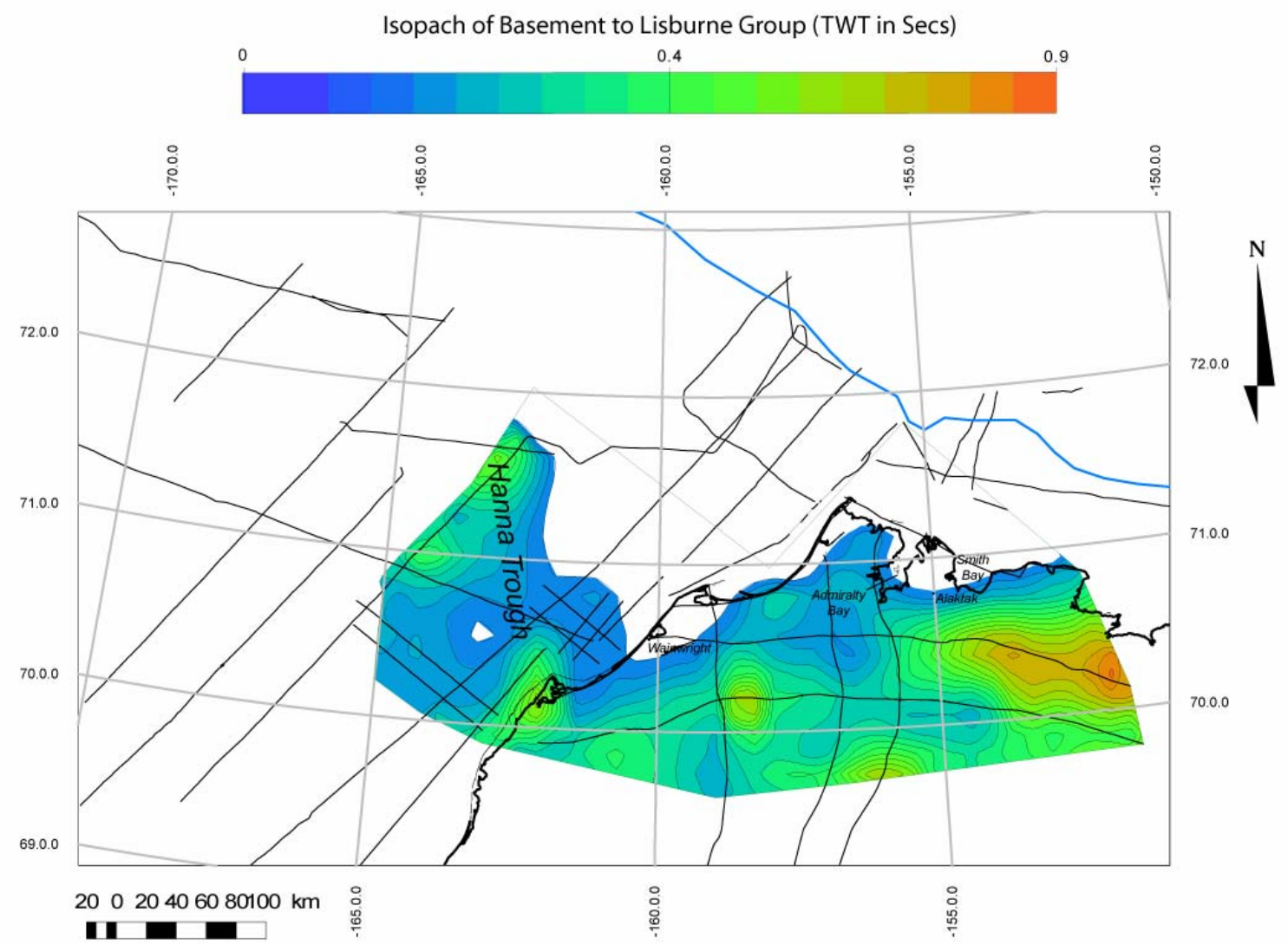

Figure 29 - Contour map showing the thickness from the top of the Lisburne Group to the basement, in TWT. The map also, clearly shows the zero or onlap edge of the Lisburne Group onlapping onto the basement. 
Isopach of Basement to Sadlerochit Group (TWT in Secs)

0

0.75

1.5

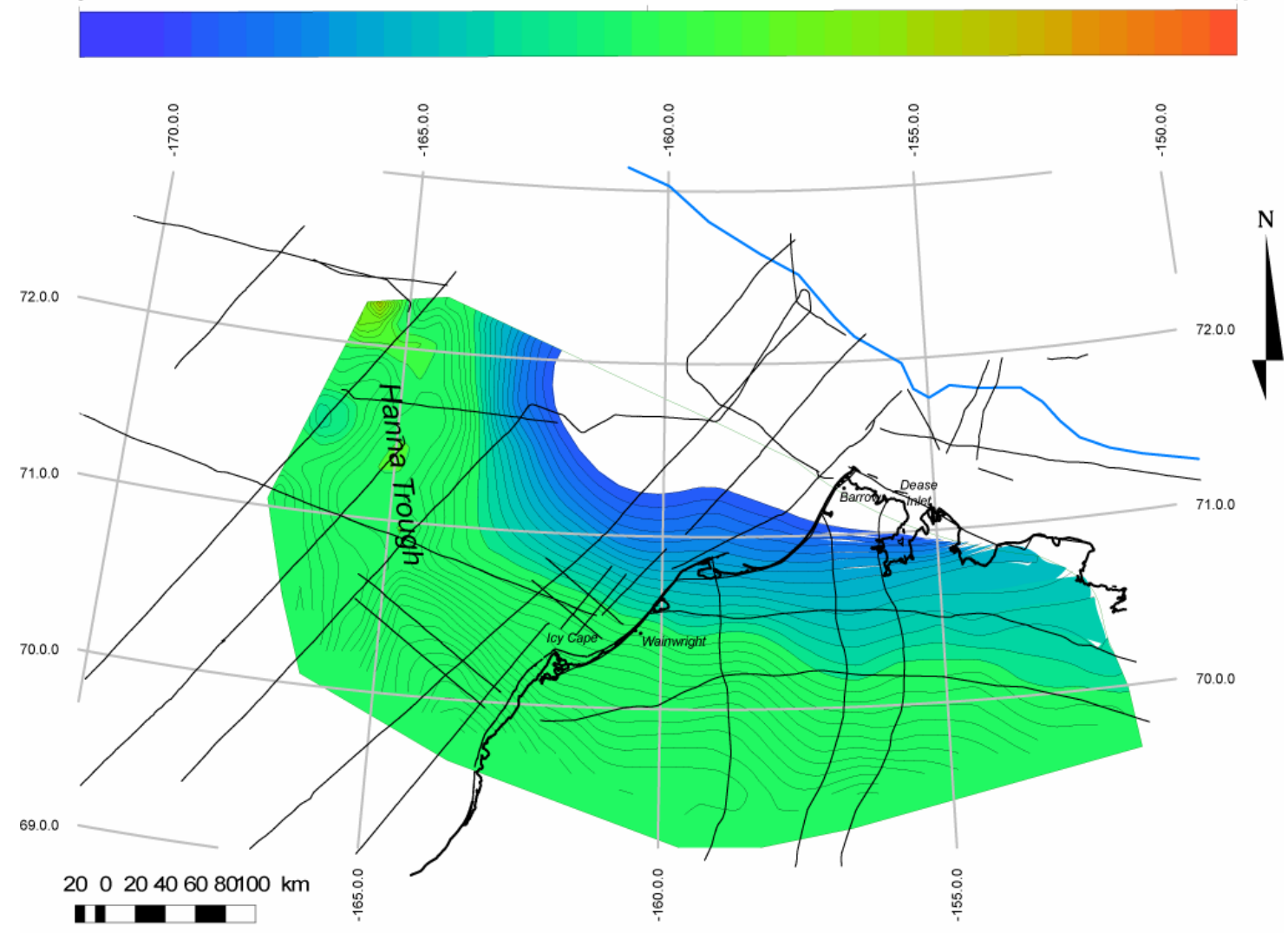

Figure 30 - Contour map showing the thickness from the top of the Sadlerochit Group to the basement, in TWT. The map also, clearly shows the zero or onlap edge of the Sadlerochit Group onlapping onto the basement. 
Chukchi Sea.

The Shublik Group (Figure 31) onlaps the basement in a C-shape, first trending south-west just offshore Barrow before turning westwards, and northwards along the eastern margin of the Hanna Trough. The Shublik Group thickens to the south across onshore Alaska, and to the west in the Hanna Trough.

The Sag River Sandstone (Figure 32) mimics the onlap of the Shublik Group, but is slightly farther north, and farther east as it onlaps through the Hanna Trough. As with the Shublik Group, the Sag River Sandstone thickens southwards across onshore Alaska, and to the west into the Hanna trough.

Younger onlaps should continue offshore to the north east and towards the Canada Basin. In this region, however, there is much difficulty in interpreting the seismic lines, due to the little seismic data available combined with the highly rifted slope sediments that made correlation very difficult and in some places nearly impossible. Also, in several places, the top of the Beaufortian Sequence disappeared off the bottom of the seismic traces making it impossible to continue the interpretation any farther, as can be seen on line 783 (Figure 25).

The Pebble Shale Unit isopach (Figure 33) was also created for completeness to show that the unit overtops the barrow arch and covers the entire study area.

\subsection{Plate Rotation}

A plate reconstruction model was created in the software program GMAP2002.

Firstly the outlines of northern Alaska and its continental shelf, along with the Canadian Arctic Archipelago and its continental shelf, were exported from ArcGIS and 


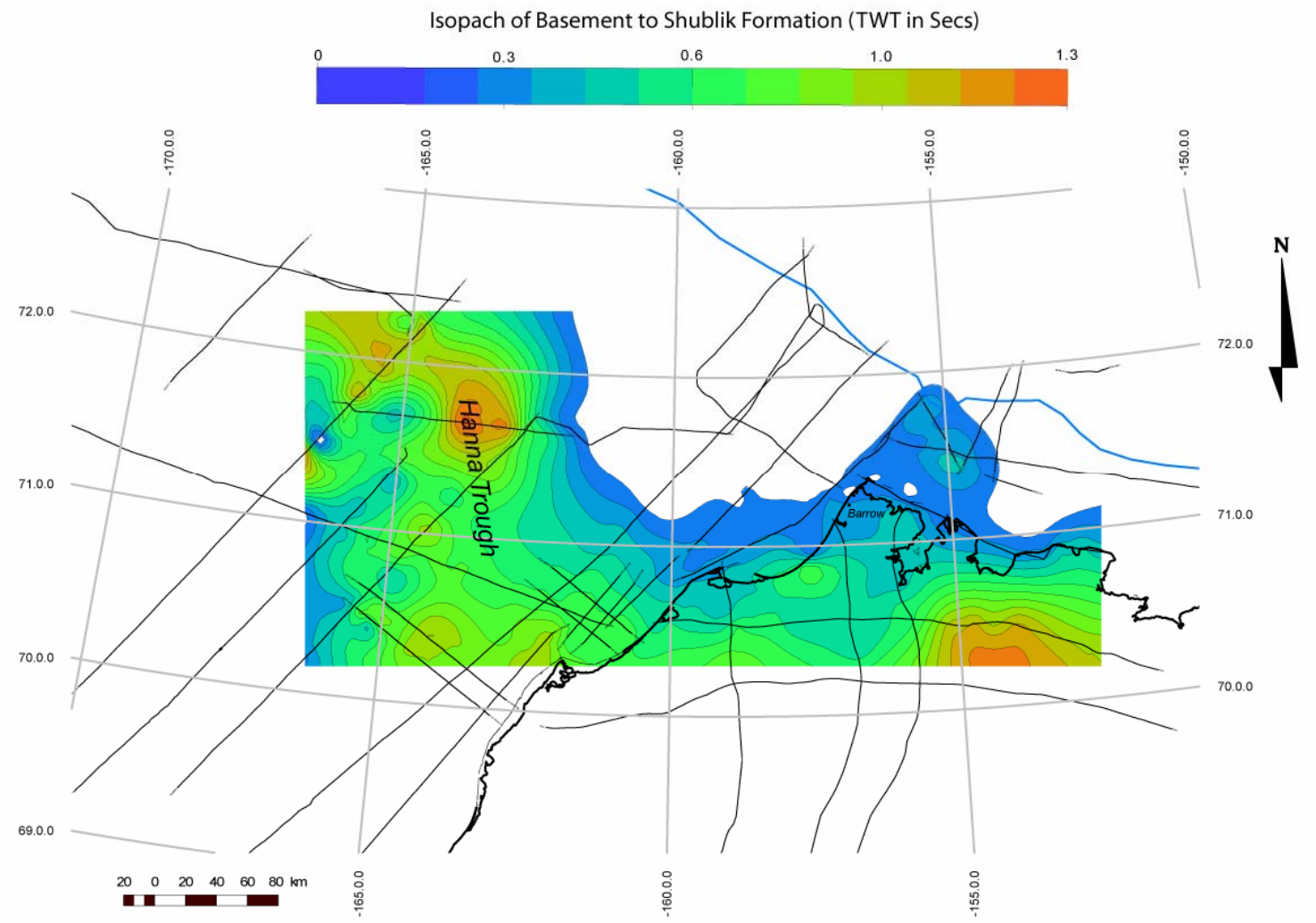

Figure 31 - Contour map showing the thickness from the top of the Shublik Formation to the basement, in TWT. The map also, clearly shows the zero or onlap edge of the Shublik Formation onlapping onto the basement. 


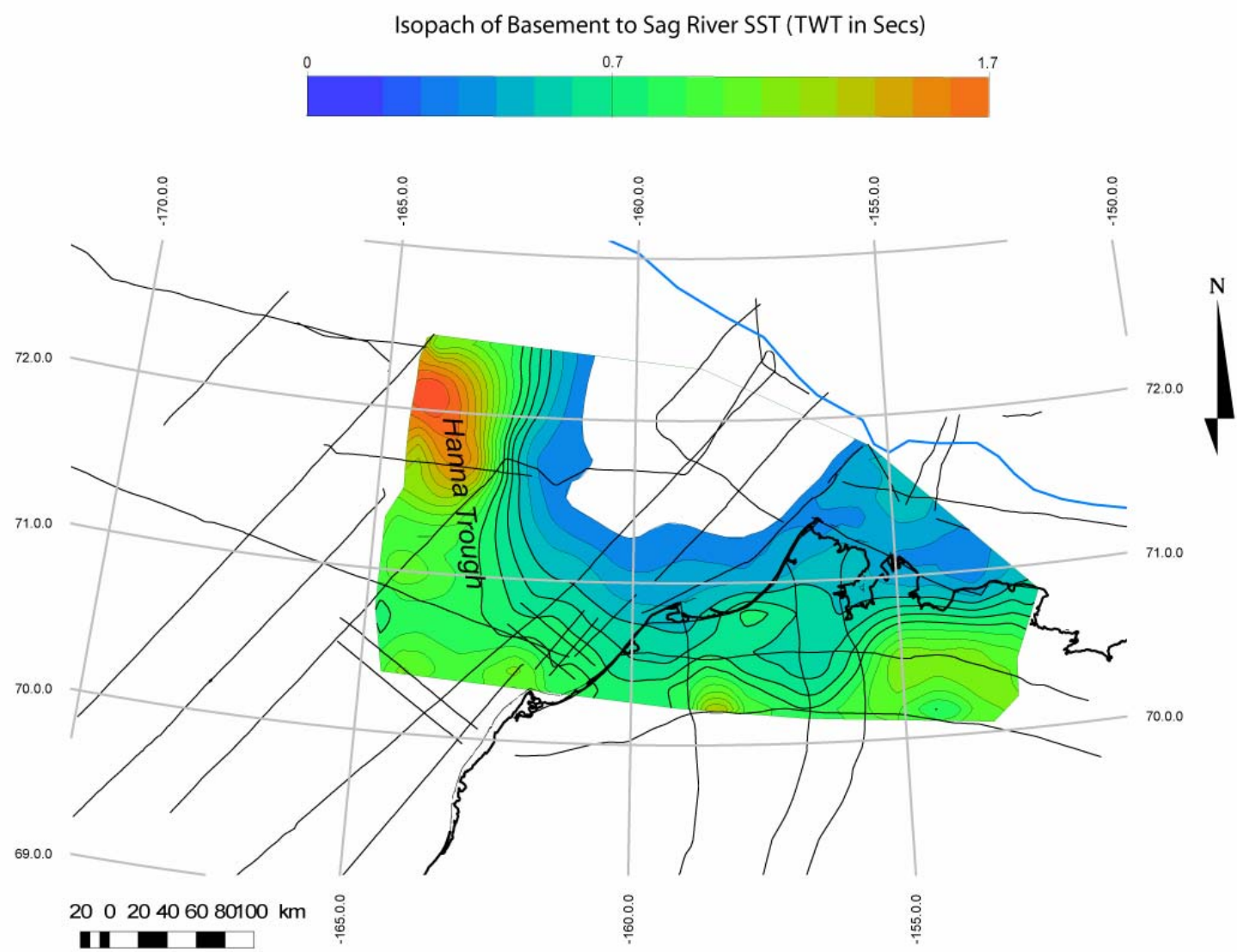

Figure 32 - Contour map showing the thickness from the top of the Sag River Sandstone to the basement, in TWT. The map also, clearly shows the zero or onlap edge of the Sag River Sandstone onlapping onto the basement. 


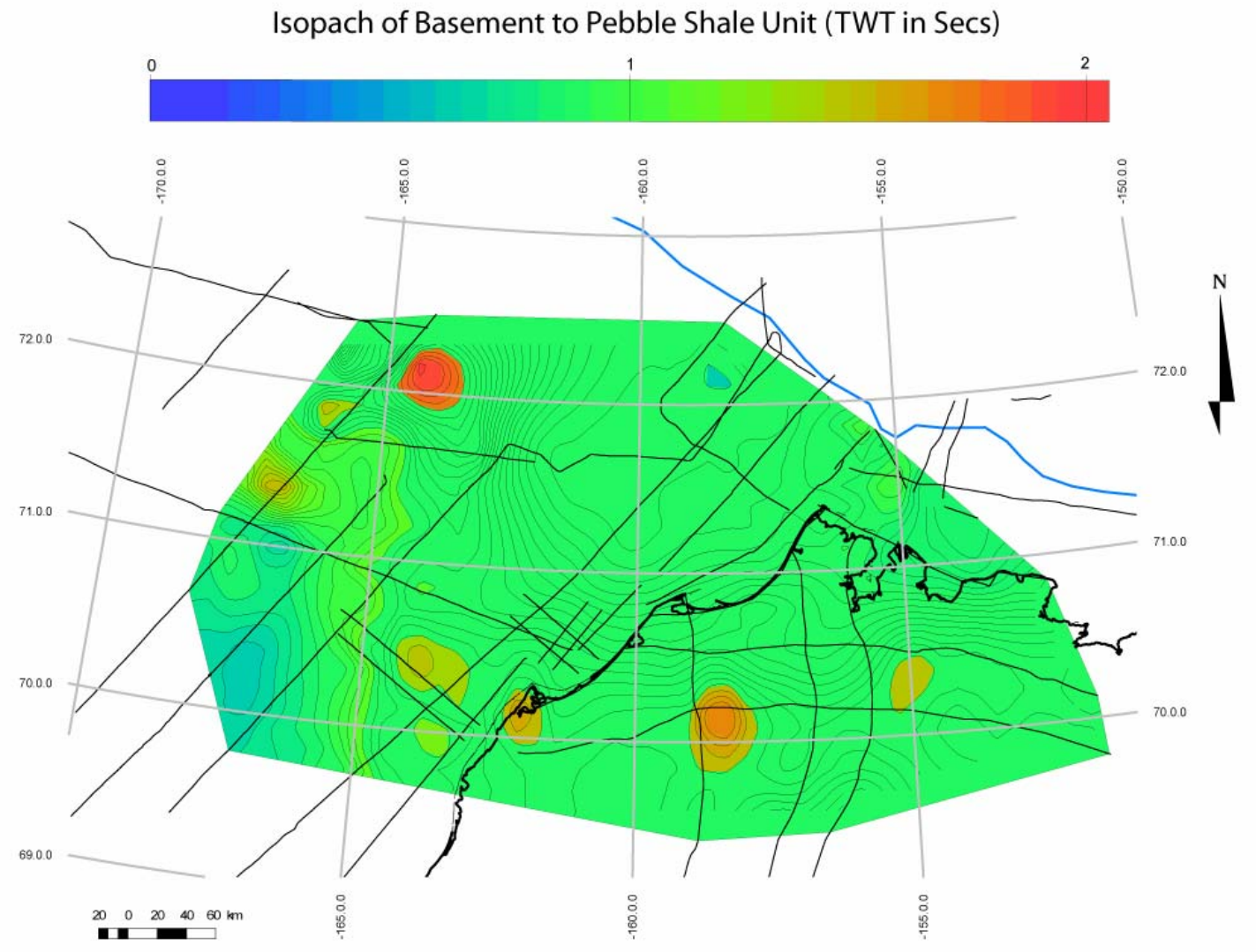

Figure 33 - Isopach map showing the thickness of rock units from the top of the pebble shale to the basement. 
transformed into a suitable file format, for importation in GMAP 2002. Using magnetic data from the Canadian Basin floor, it was determined that the opening of the basin must have occurred between the Lower Cretaceous Unconformity at around 135Ma until the onset of the Cretaceous long normal polarity episode (C34) at 120Ma. Various attempts were made to create a suitable tectonic plate reconstruction, using Euler poles, to rotate the Alaskan North Slope to a position that matched the Barrow Arch next to Prince Patrick Island in the Canadian Arctic Archipelago.

The onlap edges (or zero edge) that were created in Landmark Geographix were imported onto the rotated Northern Alaska plate, and compared with the onlap edges that had previously been documented by the Canadian Geological Survey on Prince Patrick Island, Canada (Brent \& Harrison, 2004).

Through manipulation of the Alaskan North Slope with respect to the Canadian Arctic Archipelago by using Euler pole rotation (Figure 34), it was found that the 200m bathymetry lines of the two plates matched each other extremely well with a Euler rotation of $60^{\circ}$ at $68.9^{\circ} \mathrm{N} 229^{\circ} \mathrm{W}$. This pole is located about $50 \mathrm{~km}$ north of the McKenzie delta, located on the continental shelf slope edge. The location and angle of rotation differs by around $50 \mathrm{~km}$ to the north and $6^{\circ}$ respectively from that of Grantz et al (1983). 


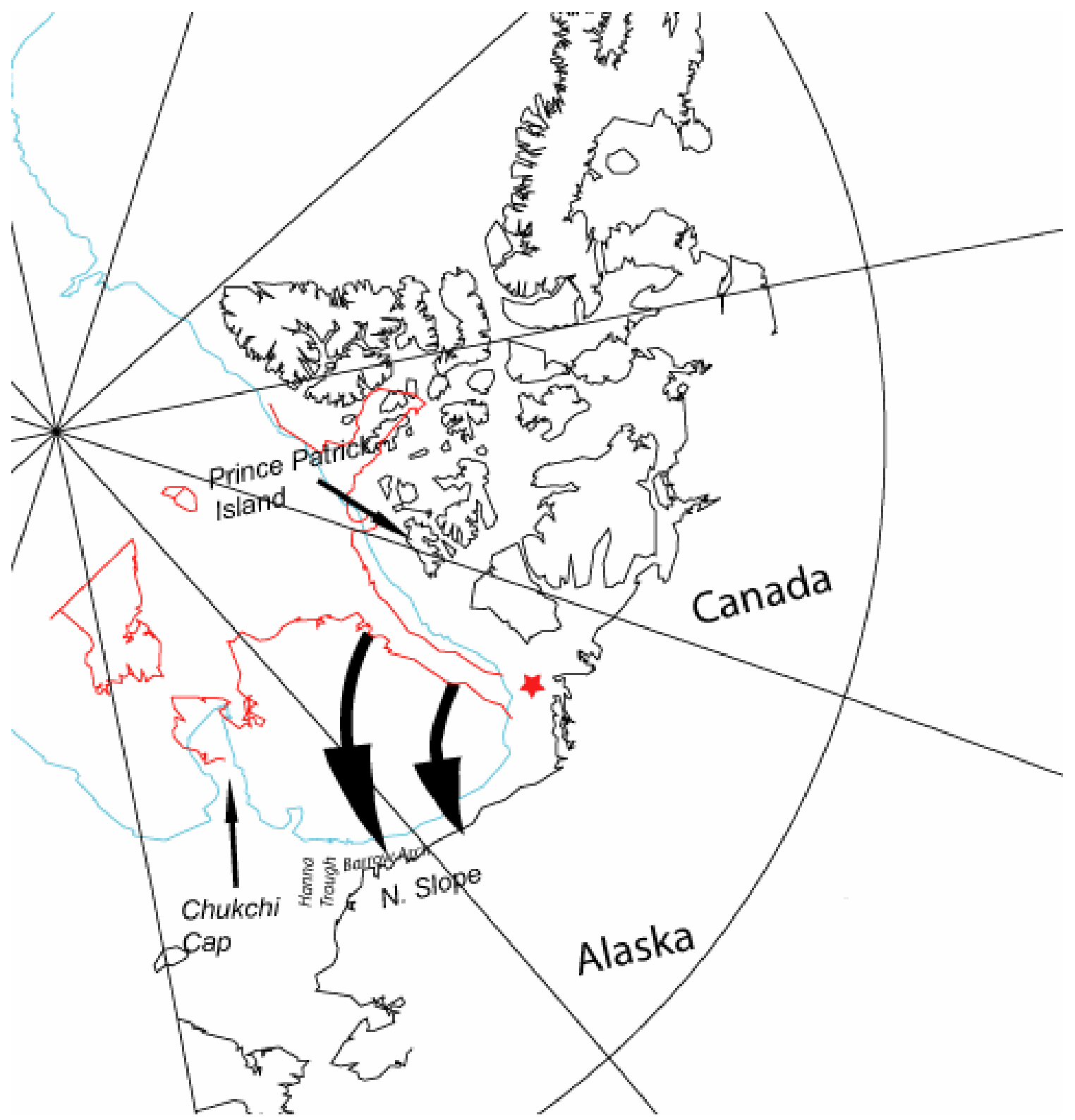

Figure 34 - Map of the Canada Basin showing the present day orientation of the coastline (black) and the $200 \mathrm{~m}$ isobath (blue), and the pre-rift location (red outline) of the North Alaskan terrane. The $200 \mathrm{~m}$ shelf edge of the restored pre-rift location of the North Alaskan subterrane fits well against the 200m shelf edge of the Canadian Shelf, rotated $60^{\circ}$ from a pole of rotation north of the McKenzie delta. The Chukchi Cap, overlaps the Canadian shelf edge, and it is suggested that it was not in its present position relative to Arctic Alaska prior to rifting. 


\section{Chapter 7: Discussion}

The gravity high observed on the gravity anomaly data (Figure 20), which runs through the center of the Canada Basin, suggests the presence of a spreading ridge. On both sides of the gravity high are several weak magnetic anomalies (Figure 21) that mirror the trend of the gravity anomaly. These observations indicate that the Canada Basin was formed by the creation of new sea-floor through spreading. The gravity and magnetic anomalies form a fan that points towards the MacKenzie delta which has previously been cited as the possible location of a rotation pole, in the rotation model (Figure 3) originally proposed by Carey (1955).

Embry (1989) proposed that the stratigraphy of the Alaskan North Slope and the Sverdrup Basin are very similar, and pointed out the fact that the rotation of Alaska would align the Sverdrup basin axes with that of the Hanna Trough found in northern Alaska.

The mapped Ellesmerian onlaps (Figure 35) show a general east-west trend along the northern coastline of Alaska, on the southern side of the Barrow arch before turning northwards along the eastern end of the Hanna Trough.

The Euler pole rotation suggested by Grantz et al. (1979) does not appear to give an accurate fit between the coastal shelf's of Alaskan North Slope and Canadian Arctic Archipelago. It also does not place the North Slope and Prince Patrick Island adjacent to each other. Although, the coastlines fit well in Grantz (1979) model, the use of the continental shelf edge gives a more accurate representation of the plate edge. The Euler pole rotation obtained through GMAP (Figure 34) seems to provide a more satisfactory fit between the continental shelves of the Alaskan and Canadian plates. In addition, such 


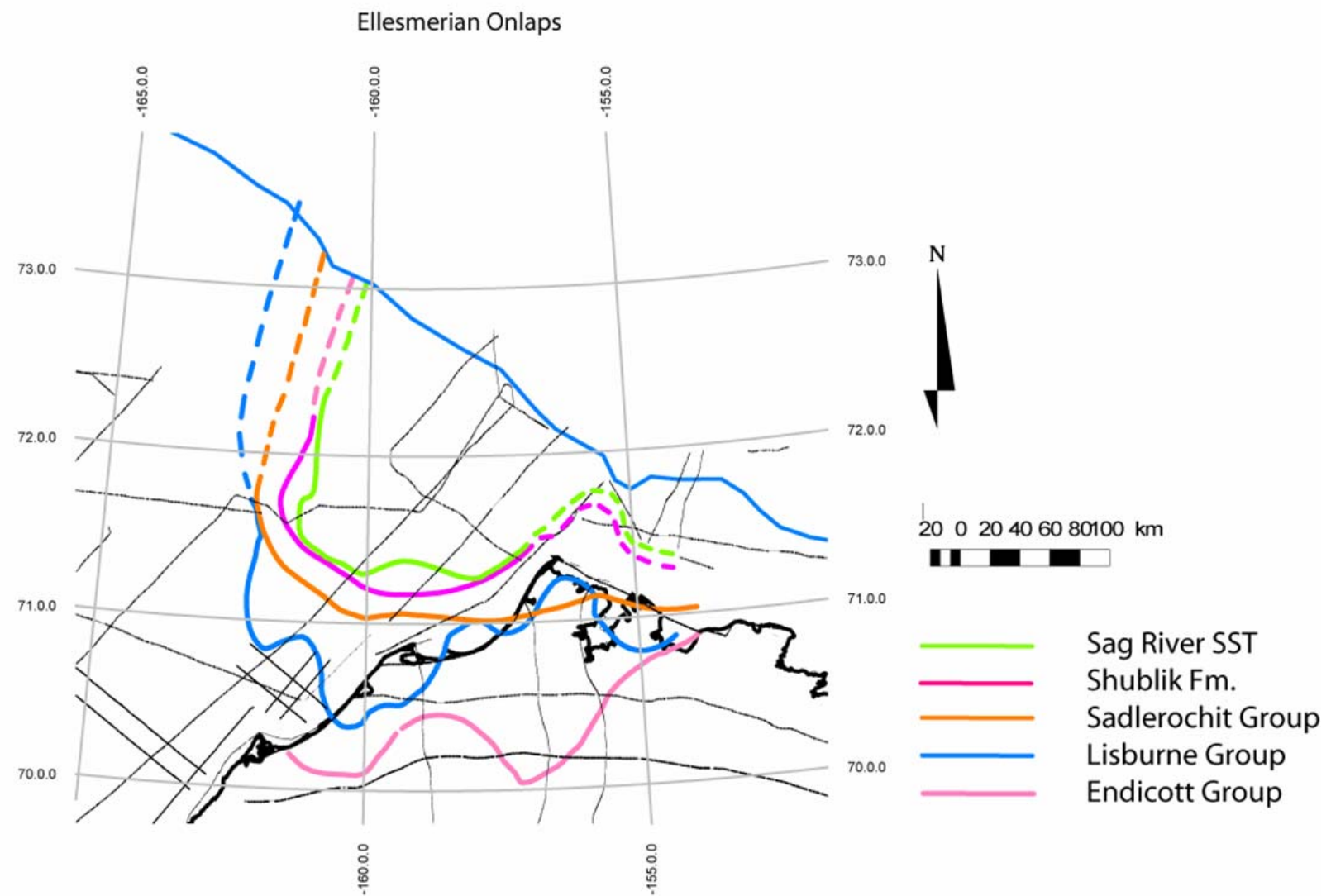

Figure 35 - Map of the North Slope showing the Ellesmerian onlaps, onlapping onto the basement northwards. Pink, Endicott Group; Blue, Lisburne Group; Orange, Sadlerochit Group; Violet, Shublik Formation; Green, Sag River Sandstone. Dashed lines show their projection towards the shelf edge where there is no seismic or well data. 
a rotation also places the North Slope of Alaska and the Sverdrup Basin adjacent to each other. This polar rotation produced in GMAP would also agree with Embry’s (1989) suggestion that the rotation of the Alaskan North Slope would align the Hanna trough with the Sverdrup Basin axes (Figure 7).

There is, however, a problem with how the Chukchi Cap and Northwind ridge fits into the rotation model, as it would appear to overlap the Canadian Arctic Archipelago (Figure 35) unless it is moved out of the way prior to rotation. Vogt (1982) suggested that the Chukchi High split away from the Canadian plate at a later stage, resulting in a younger rift system in the northern part of the Canada Basin. Another possibility is that the Chukchi high was actually present north of the Canada Basin prior to rifting, and was emplaced onto the Alaskan North Slope through strike-slip movement along the northern Alaskan coastline contemporaneously with the rifting and opening of the Canada Basin (Figure 36). A third, and the most probable explanation is that the Chukchi Cap rotated clockwise away from the Siberian margin contemporaneously with the opening of the Canada Basin (Figure 37). Movement following rifting of the Canada Basin would have resulted in folded sedimentary strata on the eastern (strike-slip model) or western (northern rifting model) flank of the Chukchi Cap that had been scraped up by its movement, however, there is very little evidence for this.

The rotation, which aligns the Hanna trough with the Sverdrup basin would mean that the Ellesmerian strata which were mapped onlapping along the eastern margin of the Hanna trough would have been trending towards the Sverdrup Basin, thus, matching the onlaps that have already been mapped by the Geological Survey of Canada on Prince Patrick Island. 


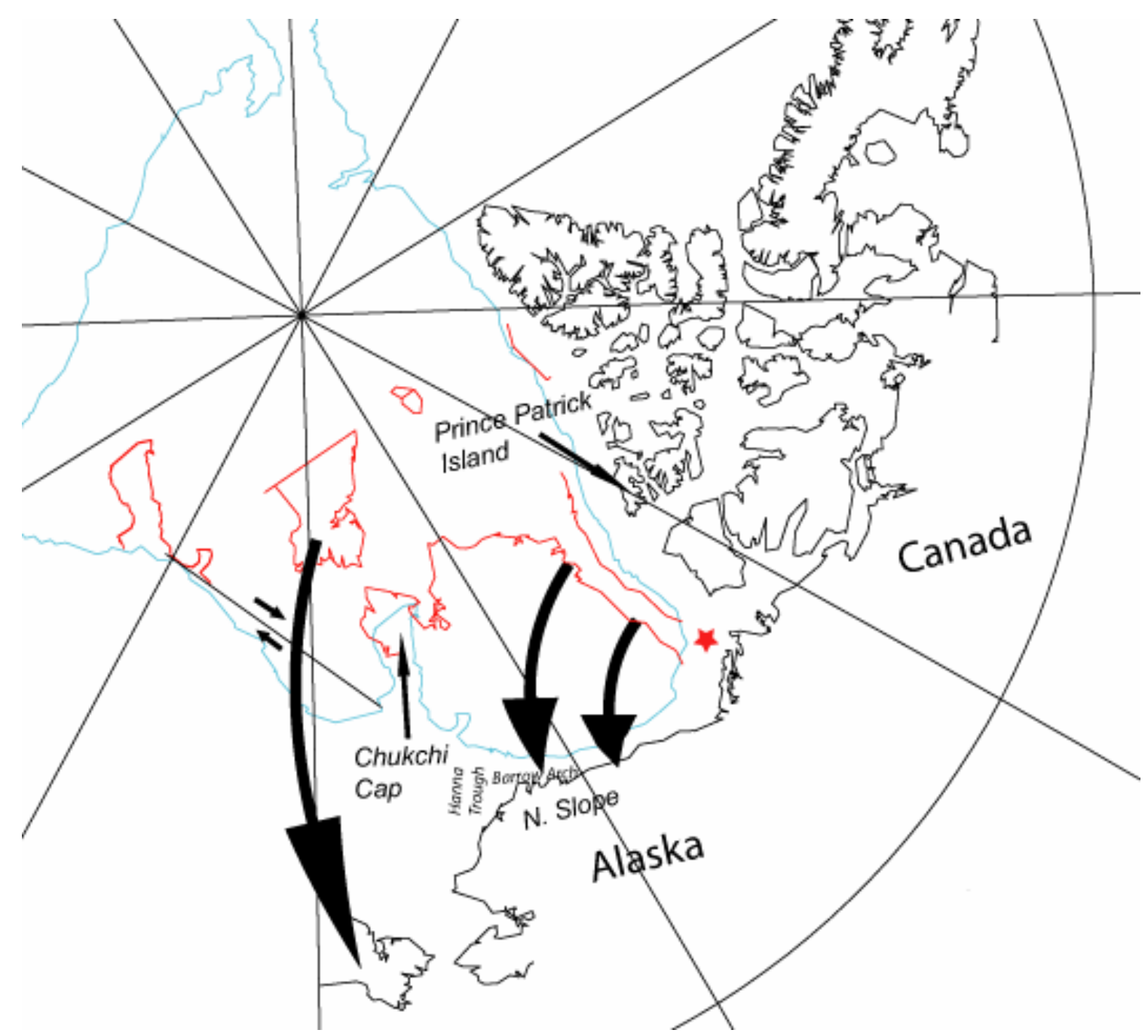

Figure 36 - Map of the Canada Basin showing the present day orientation, and the pre-rift location (red outline) of the North Alaskan terrane. The $200 \mathrm{~m}$ shelf edge of the restored pre-rift location of the North Alaskan subterrane fits well against the $200 \mathrm{~m}$ shelf edge of the Canadian Shelf, rotated $60^{\circ}$ from a location north of the McKenzie delta. The Chukchi Cap, does not appear to fit well against the Canadian shelf edge, it is suggested that the Chukchi Cap was originally located on the Siberian shelf edge, and moved due to strike-slip motion concurrent with the later stages of rotation of northern Alaska, accreting onto the Alaskan shelf at it's present day position. 


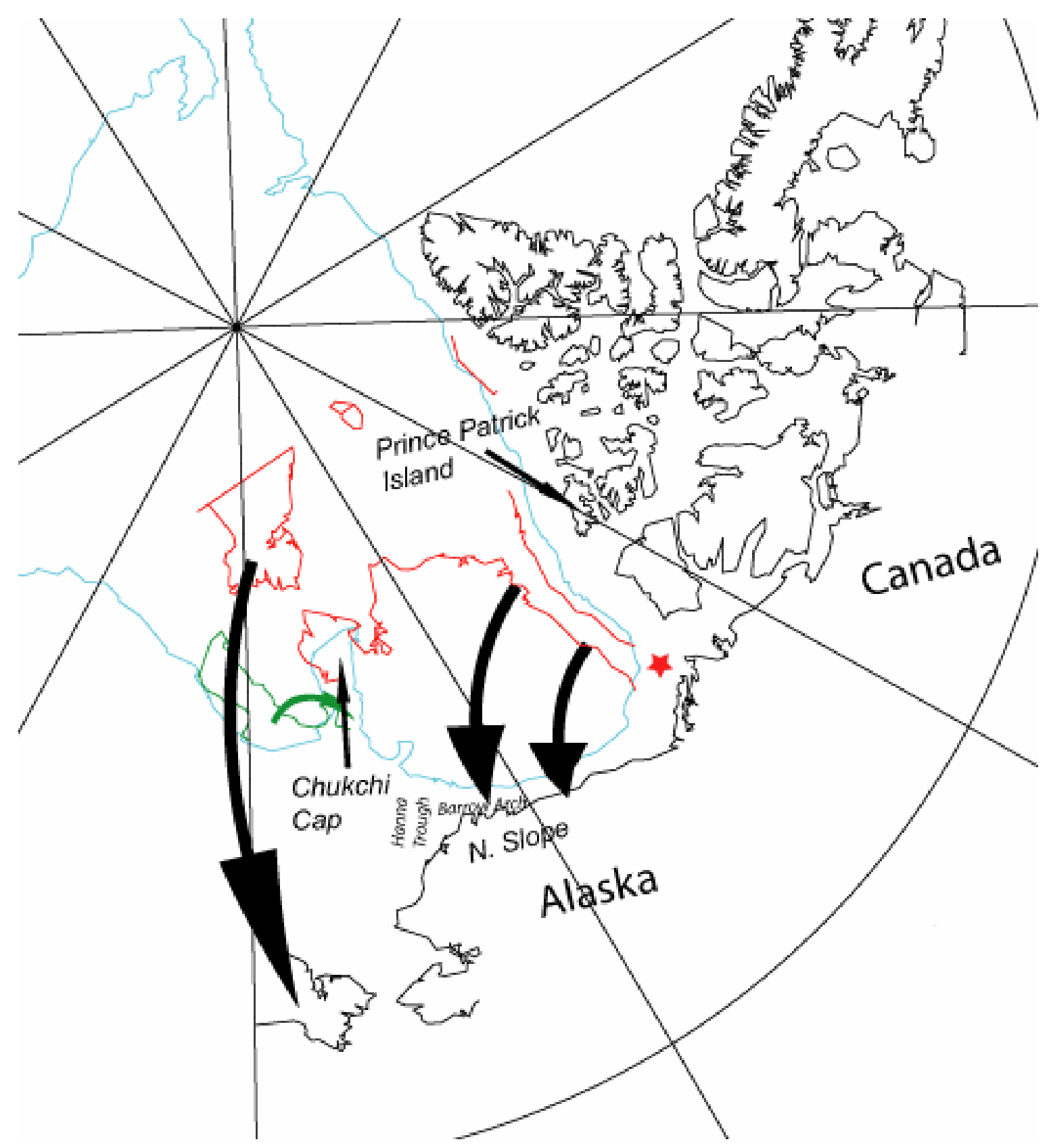

Figure 37 - Map of the Canada Basin showing the present day orientation, and the pre-rift location (red outline) of the North Alaskan terrane. The $200 \mathrm{~m}$ shelf edge of the restored pre-rift location of the North Alaskan subterrane fits well against the $200 \mathrm{~m}$ shelf edge of the Canadian Shelf, rotated $60^{\circ}$ from a location north of the McKenzie delta. The Chukchi Cap, does not appear to fit well against the Canadian shelf edge, it is suggested that the Chukchi Cap was originally located on the Siberian margin, and rotated away from this margin to it's present day location. 
The mapped onlaps on the North Slope of Alaska trend across the northern coastline of Alaska, before turning northwards in the Chukchi Sea, along the eastern margin of the Hanna trough. As aforementioned, rotating northern Alaska counterclockwise around a pole just north of the McKenzie Delta has the effect of aligning the axis of the Hanna trough with that of the Sverdrup Basin. On comparing the onlaps (Figure 38) of the rotated northern Alaska plate next to the onlaps on Prince Patrick Island, there would appear to be a matching trendline which is consistent with the hypothesis for a rotational opening of the Canada Basin. However, although the mapped onlaps on the North Slope, and on Prince Patrick Island do appear to trend towards each other (Figure 37), some caution should be taken in suggesting that they are stratigraphic equivalents, as due to the extensional tectonics, rifting and complexity of strata observed on the shelf slope (Figure 25) makes it difficult to interpret the horizons as you move offshore from the Alaskan coastline. This difficulty in the interpretation of the seismic data, means that the horizons could not be extended as far out to sea as the continental slope break. This leaves a relatively large "gap” in the data, when the Alaskan plate is rotated back to its pre-rift position. Therefore, whilst the mapping of the onlaps does suggest that it is entirely possible that they could be stratigraphic equivalents between the North Slope and the Sverdrup Basin, it does not give sound evidence that they are.

Whilst, the lack of seismic data does not provide definite evidence for the rotational opening, the Franklinian, and younger formations isopach maps do give some insight into the evolution of the North Slope Basin itself. The Mississippian Endicott Group was deposited from east to west along a narrow axis between the Brooks Range to the south and the Barrow Arch to the north, with thickening to the south. During the 
Pennsylvanian the Lisburne Group was deposited along this same east west axis, spilling over into the Hanna trough, which is a Devonian sag feature (probably due to earlier rifting in the Chukchi sea). The Lisburne group covers a larger area, and is found to thin out farther north than the Endicott Group. Continued deposition in the basin produced the later Sadlerochit Group (Permian - Lr. Triassic), Shublik Formation (Triassic) and Sag River Sandstone (Up. Triassic) which follow similar depositional patterns spreading from east to west, before turning northwards on reaching the Hanna Trough. It can be seen that whilst the basin axis remains east-west throughout this timeframe that deposition in this basin advances northwards progressively over time. 


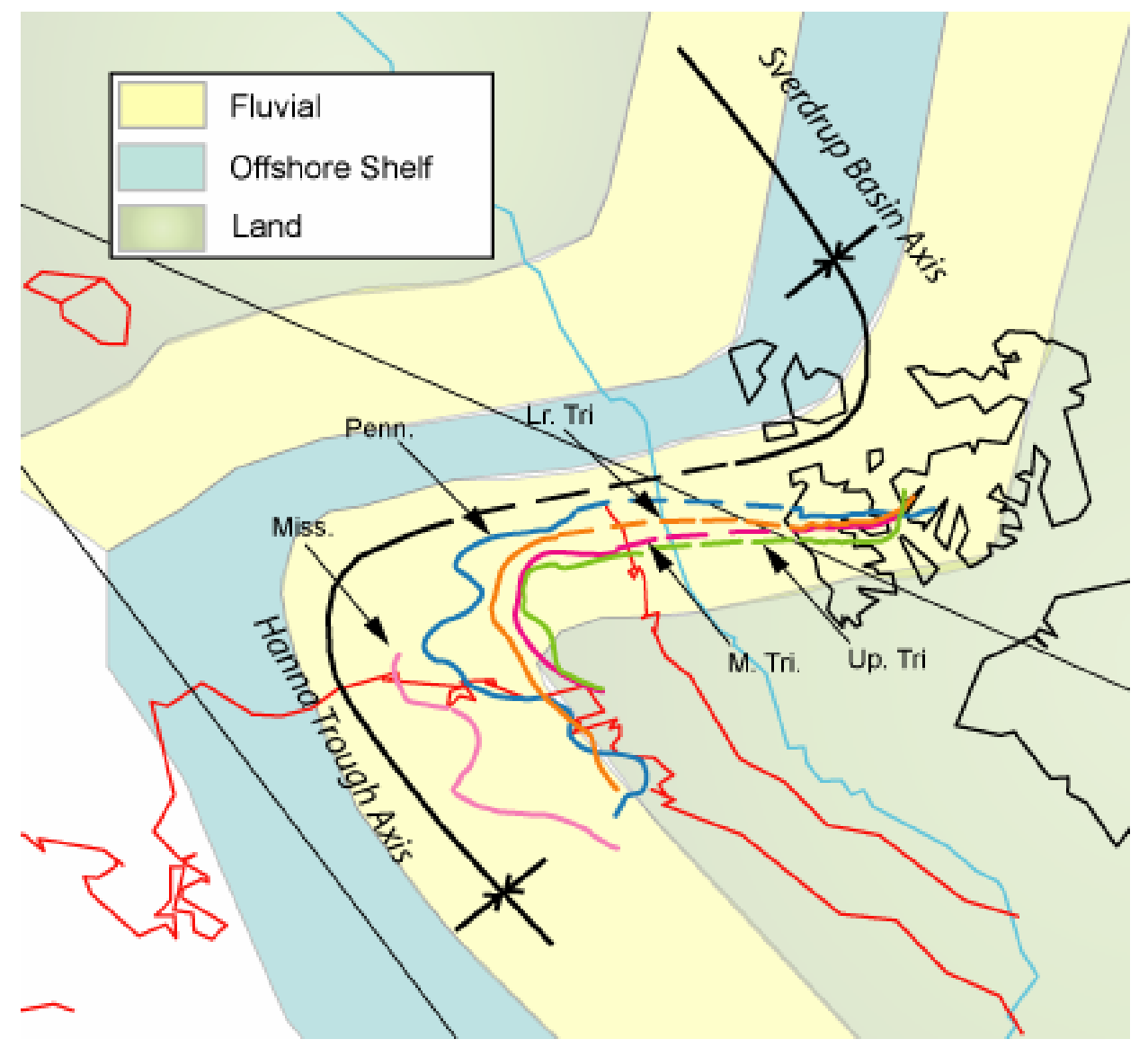

Figure 38 - Reconstruction showing a comparison of how the Ellesmerian onlaps on the Barrow Arch align with onlaps of similar age on Prince Patrick Island Canada. Pink represents the Mississippian (Endicott Group); Blue represents the Pennsylvanian (Lisburne Group); Orange represents the Permian-Early Triassic (Sadlerochit Group); Magenta represents the Middle Triassic (Shublik Formation); and the green represents the Late Triassic (Sag River Formation). The dashed lines represent the inferred edges of the onlaps. It should be noted that whilst the mapped North Slope strata are not exact equivalents of the mapped onlaps of Figure 2, due to the available data they are the closest equivalents that can be found. The Black outlines and the blue line represent the Canadian Islands and the Canadian Shelf edge respectively. While, the red lines represent the restored Alaskan coastline and shelf edge. The basin axis of the Hanna Trough and Sverdrup Basin, along with the Triassic Paleogeography, adapted from figures by Embry (1989) (Figures 7 \& 15) have also been added. 


\section{Chapter 8: Conclusions}

The gravity and magnetic anomaly data would appear to support a model of seafloor spreading for the formation of the Canada Basin. Of all the sea-floor spreading models, due to the directionality of the anomalies, the rotational model would appear to be the most likely explanation for the observed pattern.

The rotation of the Northern Alaskan plate $60^{\circ}$ counter-clockwise around a pole at $68.9^{\circ} \mathrm{N}, 229^{\circ} \mathrm{W}$ would appear to match the continental shelves of Alaska and the Canadian plates almost perfectly, with the exception of the Chukchi High. The Chukchi High may have been moved to it’s present day position syntectonically as the rifting and opening of the Canada Basin. The Chukchi High having been emplaced from the North along a strike-slip fault bordering the Siberian shelf edge.

This rotational opening aligns the axes of the Hanna Trough and the Sverdrup Basin. The mapped Ellesmerian onlaps in the Alaskan North Slope currently trend northwards along the eastern margin of the Hanna Trough, which once rotated would appear to align the onlaps with the onlaps of the strata of similar age on Prince Patrick Island. Although this would appear to suggest that there is a possibility that the Ellesmerian strata of the North Slope are the stratigraphic equivalents of the onlapping strata on Prince Patrick Island, there is a large "gap" in the data due to the difficulties in interpreting the highly deformed strata on the Alaskan continental slope. Therefore, this research should be thought of as consistent with the hypothesis of a rotational opening of the Canada Basin, rather than further proof. 


\section{REFERENCES CITED}

Agena, W.F., Lee, M.W. \& Hart, P.E., 2000. Reprocessing of Multi-channel SeismicReflection Data Collected in the Beaufort Sea. USGS Open-File Report 00-46.

Agena, W.F., Lee, M.W., and Hart, P.E., 2001. Reprocessing of Multi-channel Seismic Reflection Data Collected in the Chukchi Sea. USGS Open-File Report 01-330.

Balkwill, H.R., 1978. Evolution of Sverdrup Basin, Arctic Canada. Am. Assoc. Pet. Geol. Bull., 62, pp 1004-1028.

Beloussov, V.V., 1970. Against the hypothesis of ocean-floor spreading. Tectonophysics, 9, pp 489-511.

Bird, K.J., 1988. Alaskan North Slope stratigraphic nomenclature and data summary for government-drilled wells. In: G. Gyrc (editor), Geology and exploration of the National Petroleum Reserve in Alaska, 1974 to 1982. U.S. Geological Society Professional Paper, 1399, pp 317-353.

Bird, K.J., 2001. Alaska: A twenty-first-century petroleum province. In: M.W. Downey, J.C. Threet, and W.A. Morgan (editors), Petroleum Provinces of the twenty-first century. AAPG Memoir 74, pp 137-165.

Bird, K.J. \& Molenaar C.M, 1992. The North Slope foreland basin, Alaska. In: R.W. Macqueen \& D.A. Leckie (editors), Foreland basins and foldbelts. AAPG Memoir 55, pp 363-393

Carey, S.W., 1955. The orocline concept in geotectonics. Royal Society of Tasmania Proceedings, 89, pp 255-288.

Christie, R.L., 1979. The Franklinian Geosyncline in the Canadian Arctic and its relationship to Svalbard. Skr. Nor. Polarinst., 167, pp 263-314.

Dutro, J.T., 1981. Geology of Alaska bordering the Arctic Ocean. In: A. Nairn, M. Churkin and F. Stehli (Editors), The Ocean Basins and Margins, 5, the Arctic Ocean. Plenum, New York, pp 21-36.

Embry, A.F., 1985. Mesozoic stratigraphy of Canadian Arctic Archipelago and implications for opening of Amerasian Basin [abstract]. Amer. Assoc. Petrol. Geol., 69, pp 253.

Embry, A.F., 1988. Middle-Upper Devonian Sedimentation in the Canadian Arctic islands and the Ellesmerian Orogeny. In: N.J. McMillan, A.F. Embry \& D.J. Glass (editors), Devonian of the World. Can. Soc. Pet. Geol. Mem., 14, pp 15-28. 
Embry, A.F., 1989. Correlation of Upper Paleozoic and Mesozoic Sequences between Svalbard, Canadian Arctic Archipelago and Northern Alaska. In: J.D. Collinson (Editor), Correlation in Hydrocarbon Exploration. Norw. Pet. Soc., Stavanger, pp 8998.

Embry, A.F., 1990. Geological and geophysical evidence in support of the hypothesis of anticlockwise rotation of Northern Alaska. Marine Geology, 93, pp 317-329.

Geological Society of Canada, http://gsca.nrcan.gc.ca/index_e.php

Grantz, A., Eittreim, S. \& Dinter, D.A., 1979. Geology and tectonic development of the continental margin north of Alaska. Tectonophysics, 59, pp 263-291.

Grantz, A. \& May, S.D., 1983. Rifting history and structural development of the continental margin north of Alaska. In: J.S. Watkins \& C.L. Drake (editors), Studies in continental marine geology. AAPG Memoir 34, pp 77-100.

Herron, E.M., Dewey, J. \& Pitman, W., 1974. Plate tectonics model for the evolution of the Arctic. Geology, 2, pp 377-380.

Hubbard, R.J., Edrich, S.P. \& Rattey, R.P., 1987. Geologic evolution and hydrocarbon habitat of the “Arctic Alaska Microplate”. Mar. Pet. Geol., 4, pp 2-35.

Kearey, P. \& Vine, F.J., 1996. Global Tectonics. Blackwell Publishing.

Kerr, J.W., 1981. Evolution of the Canadian Arctic islands; a transition between the Atlantic and Arctic Oceans. In: A. Nairn, M. Churkin \& F. Stehli (Editors), The Ocean Basins and Margins, 5, The Arctic Ocean. Plenum, New York, pp 105-199.

Laxon, S and D. C McAdoo, 1998, Satellites Provide New Insights into Polar Geophysics, EOS, Transactions AGU, 79 (6), 69-72.

Lawver, L.A. \& Scotese, C.R., 1990. A review of tectonic models for the evolution of the Canada Basin. In: A. Grantz, L. Johnson \& J.F. Sweeney (Editors), The Geology of North America, L, The Arctic Ocean region, Boulder, Colorado, Geological Society of America.

Legacy Data Archive, http://nerslweb.cr.usgs.gov/

Lerand, M., 1973. Beaufort Sea. In: R.G. McCrossan (Editor), The future petroleum provinces of Canada: their geology and potential. Can. Soc. Pet. Geol. Mem., 1, pp 315-386.

Mair, J.A. \& Lyons, J.A., 1981. Crustal structure and velocity anisotrophy beneath the Beaufort Sea. Can. Jour. Ear. Sci., 18, pp 724-741. 
Mason, R.G. \& Raff, A.D., 1961. Magnetic survey off the west coast of North America, 32 degrees N. latitude to 42 degrees N. latitude, Geol. Soc. Am. Bull., 72, 1259-1265.

Metz, P.A., Egan, A. \& Johanson, O., 1982. Landsat linear features and incipient rift system model for origin of base-metal and petroleum resources in northern Alaska. In: A.F. Embry \& H.R. Balkwill (Editors), Arctic geology and geophysics, Can. Soc. Pet. Geol. Memoir 8, pp 101-112.

Molenaar, C.M., Bird, K.J., \& Kirk,, A.R., 1987. Cretaceous and Tertiary stratigraphy of northeastern Alaska. In: I. Tailleur \& P. Weimer (Editors), Alaskan North Slope geology, Bakersfield, California, Soc. Econ. Paleo. Min. Pac. Sec. and Alaskan Geol. Soc, Book 50, pp 513-528.

Moore, T.E., Wallace, W.K., Bird, K.J., Karl, S.M., Mull, C.G. \& Dillon, J.T., 1994. Geology of northern Alaska. In: G. Plafker \& H.C. Berg (Editors), The Geology of Alaska, Geol. Soc. Amer., the geology of North America, G-1, pp 49-140.

Morrell, G.R., 1995. Petroleum Exploration in Northern Canada: A Guide to Oil and Gas Exploration and Potential, Minister of Public Works and Government Services Canada.

NAMSS, 2004. http://walrus.wr.usgs.gov/NAMSS/

ODP Database, 2003, http://www-odp.tamu.edu/database/

Ogg, J.G., 1995. Magnetic polarity time scale of the Phanerozoic. Global Earth Physics, Handbook of Physical Constants, AGU Reference Shelf 1, pp 240.

Pogrebitskiy, Y.Y., 1976. The geodynamic system of the Arctic Ocean and its structural evolution. Int. Geol. Review, 20, pp 1251-1266.

Pogrebitskiy, Y.Y., and 8 others, 1984. Endogenic differentiation of matter in the geodynamic system of the Arctic Ocean, $27^{\text {th }}$ International Geological Congress, colloquium 4, pp 13-29.

Pushcharovskiy, Y.M., 1976. Tectonics of the Arctic Ocean Basin. Geotectonics, 10, pp 85-91.

Raff, A.D. \& Mason, R.G., 1961. Magnetic survey off the west coast of North America, 40 degrees N. latitude to 52 degrees N. latitude. Geol. Soc. Am. Bull., 72, 1267-1270.

Tailleur, I. \& Brosge, W.P., 1970. Tectonic history of Northern Alaska. In: W.L. Adkinson \& M.M. Brosge (Editors), Proceedings of the Geological Seminar on the North Slope of Alaska. Pac. Sect. Am. Assoc. Pet. Geol., Los Angeles, California, pp E1-E19. 
Taylor, P.T., Kovacs, L.C., Vogt, P.R. \& Johnson, G.L., 1981. Detailed aeromagnetic investigation of the Arctic Basin, 2. Jour. Geophys. Res., 86, pp 6323-6333.

Verhoef, J., Roest, W.R., Macnab, R., Arkani-Hamed, J. \& Members of the Project team, 1996. Magnetic anomalies of the Arctic and North Atlantic Oceans and adjacent land areas. Geol. Soc. Can. Open File 3125.

Vine F J \& Matthews, D H., 1963. Magnetic anomalies over oceanic ridge. Nature, 199, pp 947-9.

Vogt, P.R., Taylor, P.T, Kovacs, L.C. \& Johnson, G.L., 1982. The Canada Basin; Aeromagnetic constraints on structure and evolution. Tectonophysics, 89, pp 295-336. 


\begin{abstract}
APPENDIX
The seismic data used to construct the isopach and structure maps used in this study can be found here. The seismic data is from three different sources, which the line numbering signifies. Lines in the range 127 - 139 (Figure 23) are from the WesternGeco data set available online at NAMSS; 803 - 823 in the Chukchi Sea (Figure 23) are from the Agena et al (2001) available on cd-rom from the USGS; Lines beginning with R- , found onland and from 770 - 783 (figure 23) from the Beaufort Sea were processed by Agena et al (2000) and is also available on cd-rom from the USGS.

Lines have been interpreted using the following nomenclature: top of the Franklinian Sequence (Brown), top of the Endicott Group (Pink), top of the Lisburne Group (Dark Blue), top of the Sadlerochit Group (Orange), top of the Shublik Formation (Magenta), top of the Sag River Sandstone (Green), top of the Kingak Shale (Light Blue), and the top of the Pebble Shale Unit (Red). Several lines in the Beaufort Sea were loaded, but contain no interpretations as it is believed that even the top of the Pebble Shale unit in this area is below the depth of the seismic survey, but have been included to show that the depth of the Lower Cretaceous strata and older are much deeper than the seismic surveys depth and also as a matter of completeness.
\end{abstract}


N-R14-1

N-KUG KRUAPEARD

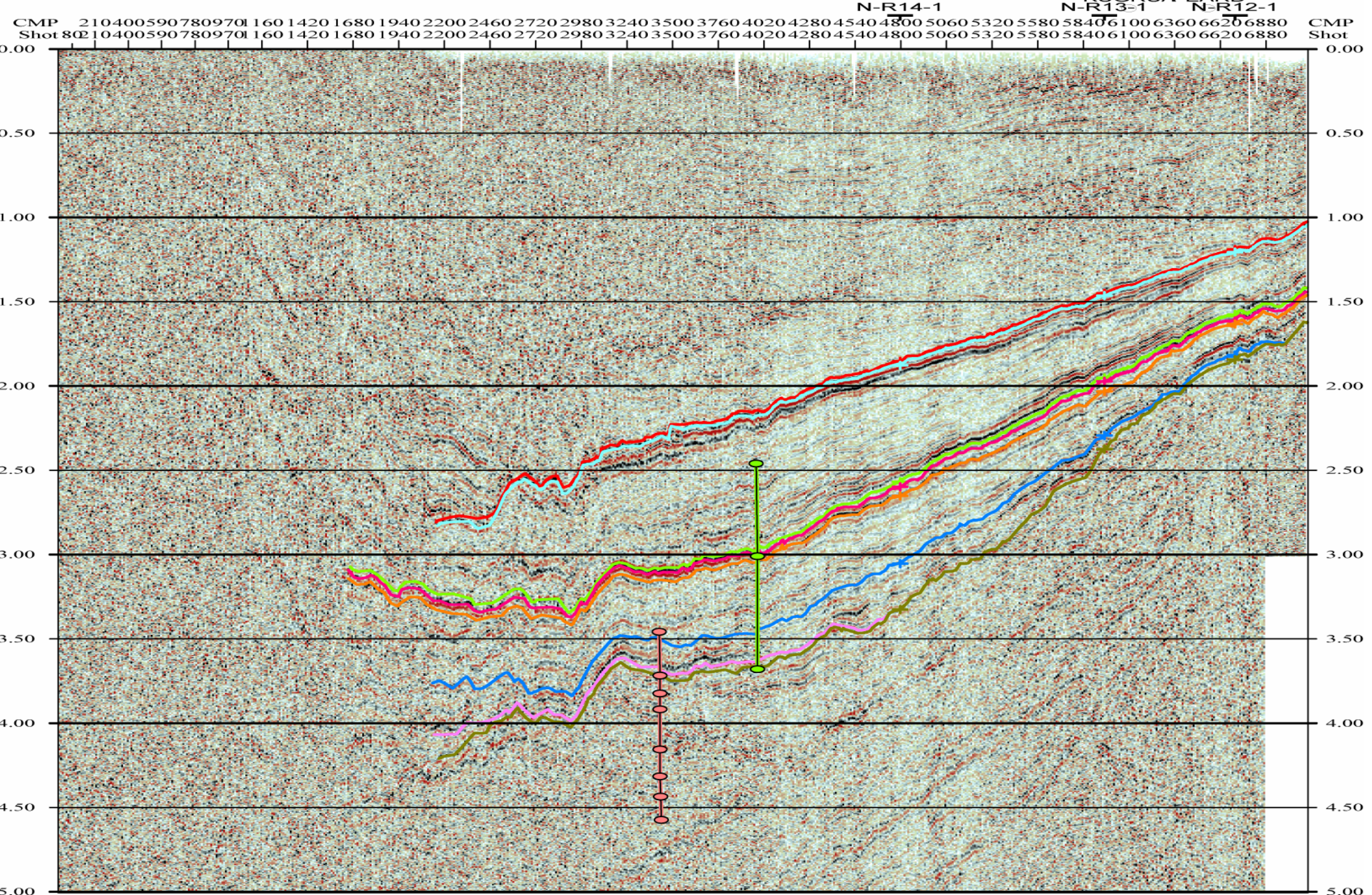

Plate 1 - Seismic Line R-4 (Agena et al, 2000) 


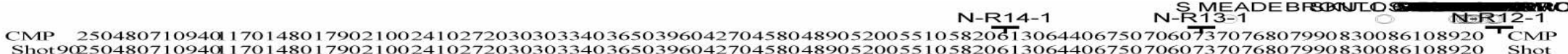

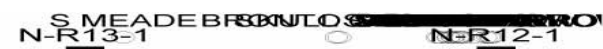
Shot9055048071094011701480179021002410272030303340365039604270458048905200551058206130644067507060737076807990830086108920 Shot

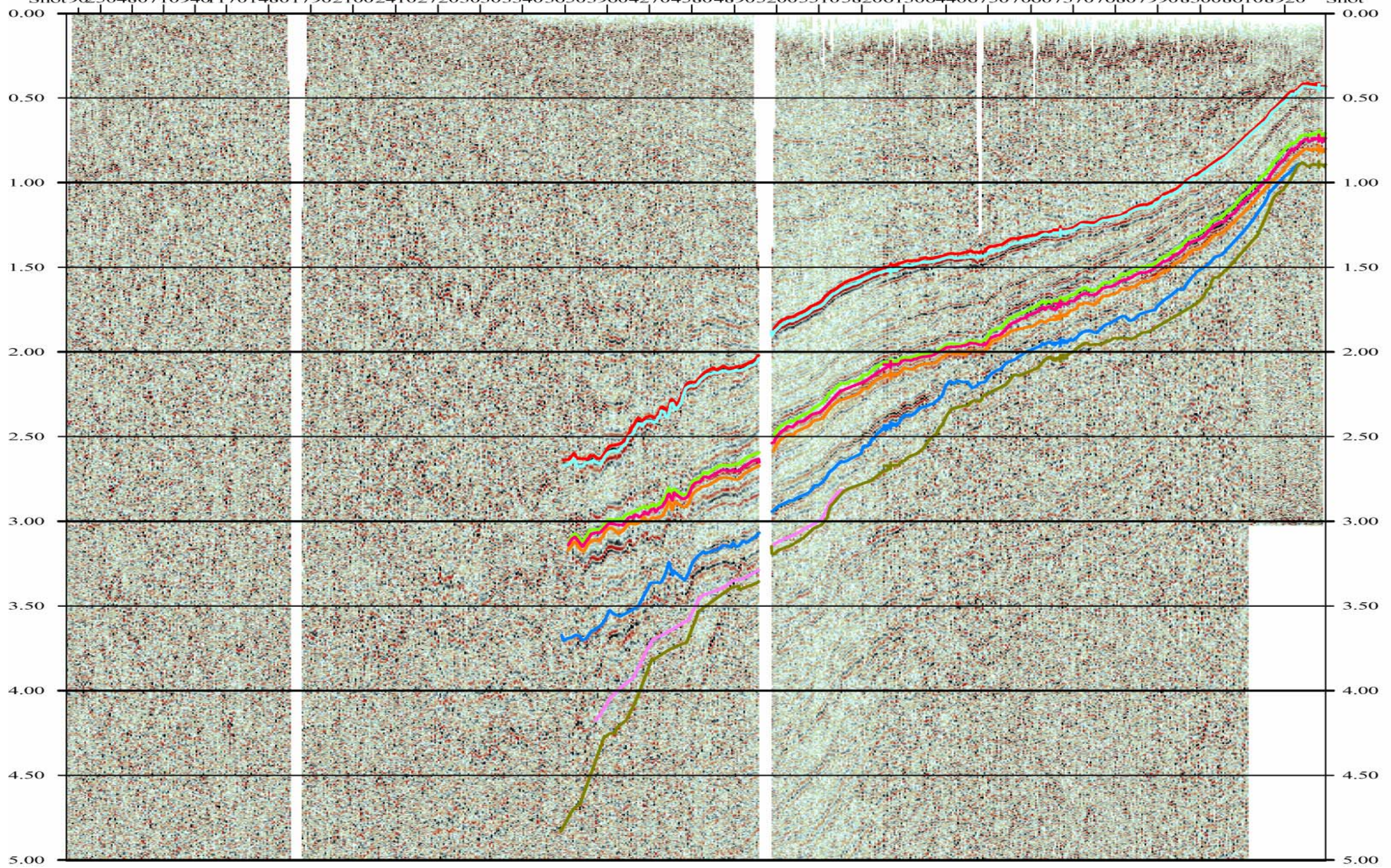

Plate 2 - Seismic Line R-5 (Agena et al, 2000) 
N-R14-1 E TORERT CMP 3906609401220159019602330270030703440381041804550492052905660603063906760713075007870824086108980935097200090 CMP

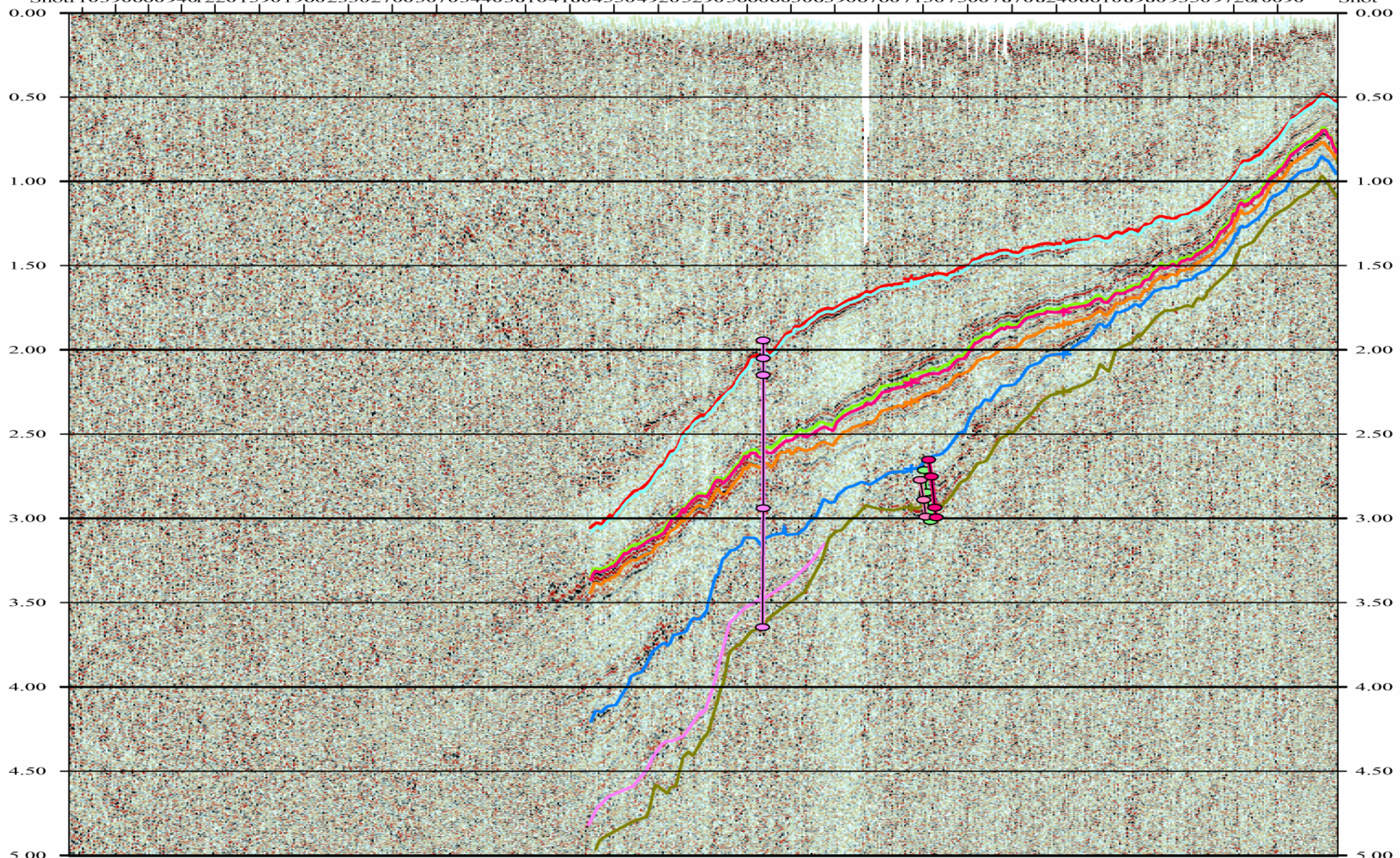

Plate 3 - Seismic Line R-6 (Agena et al, 2000) 


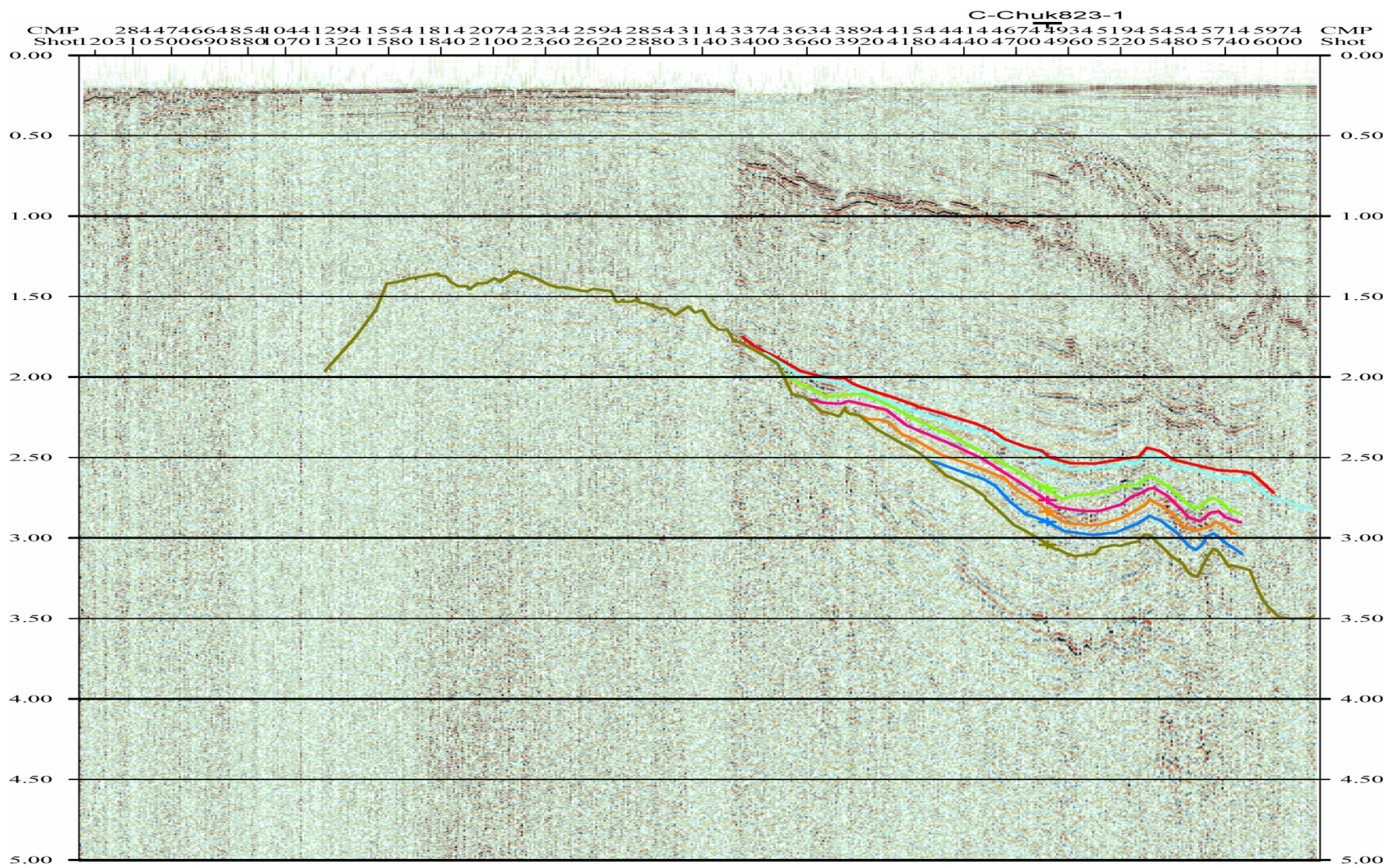

Plate 4 - Seismic Line R-11 (Agena et al, 2000) 
TUNALIK

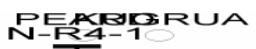

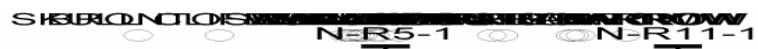

CMP 250490730970121015301850217024902810313034503770409044104730505053705690601063305605069707290 CMP $0.00 \mathrm{r}$

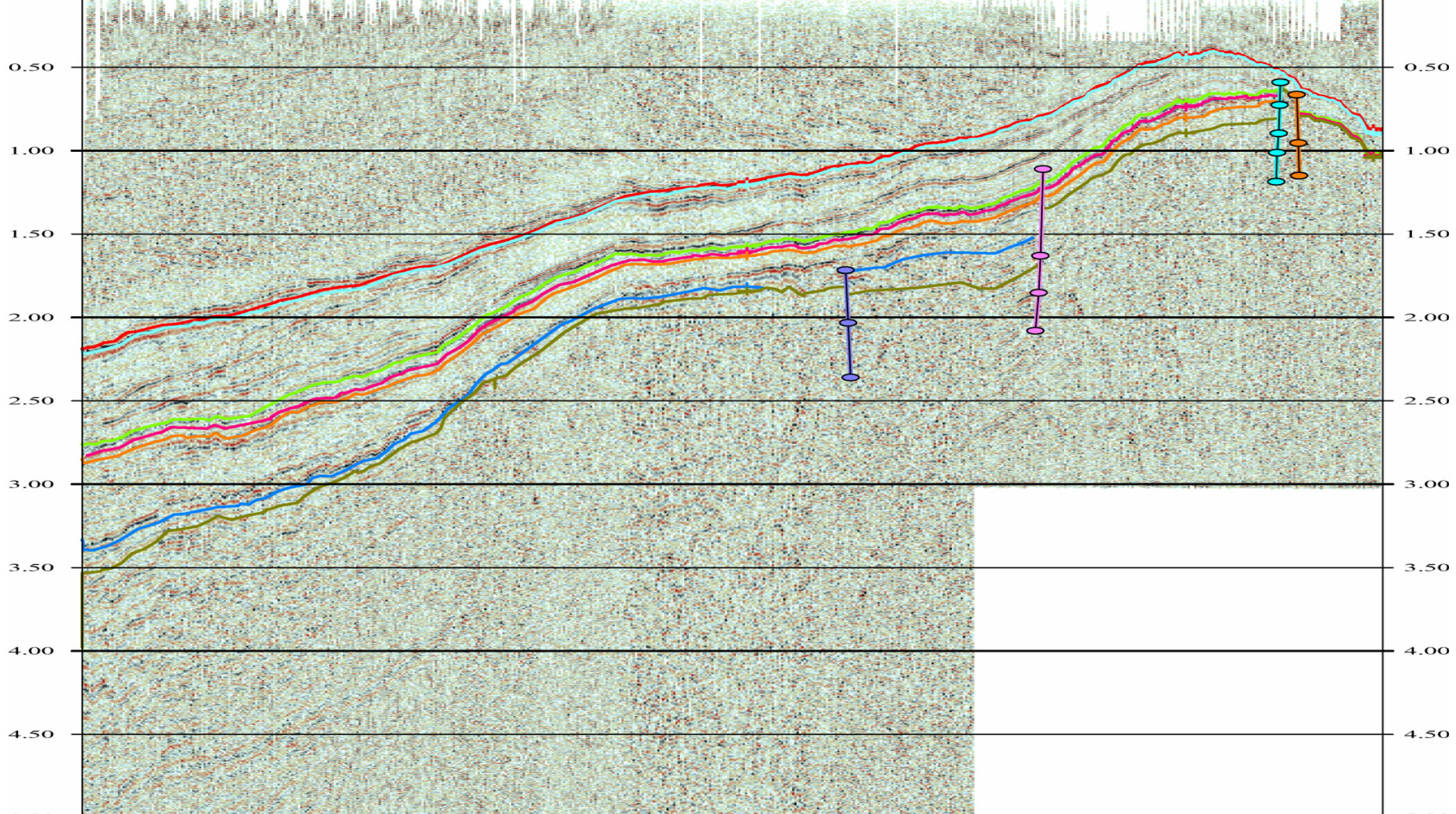

Plate 5 - Seismic Line R-12 (Agena et al, 2000) 


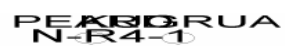

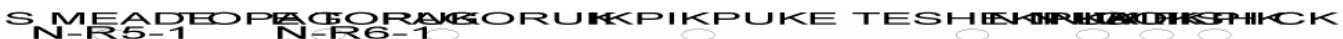
CMP 25049073097912101530185021702490281031306450377040904419473050505370569060106330 CMMP

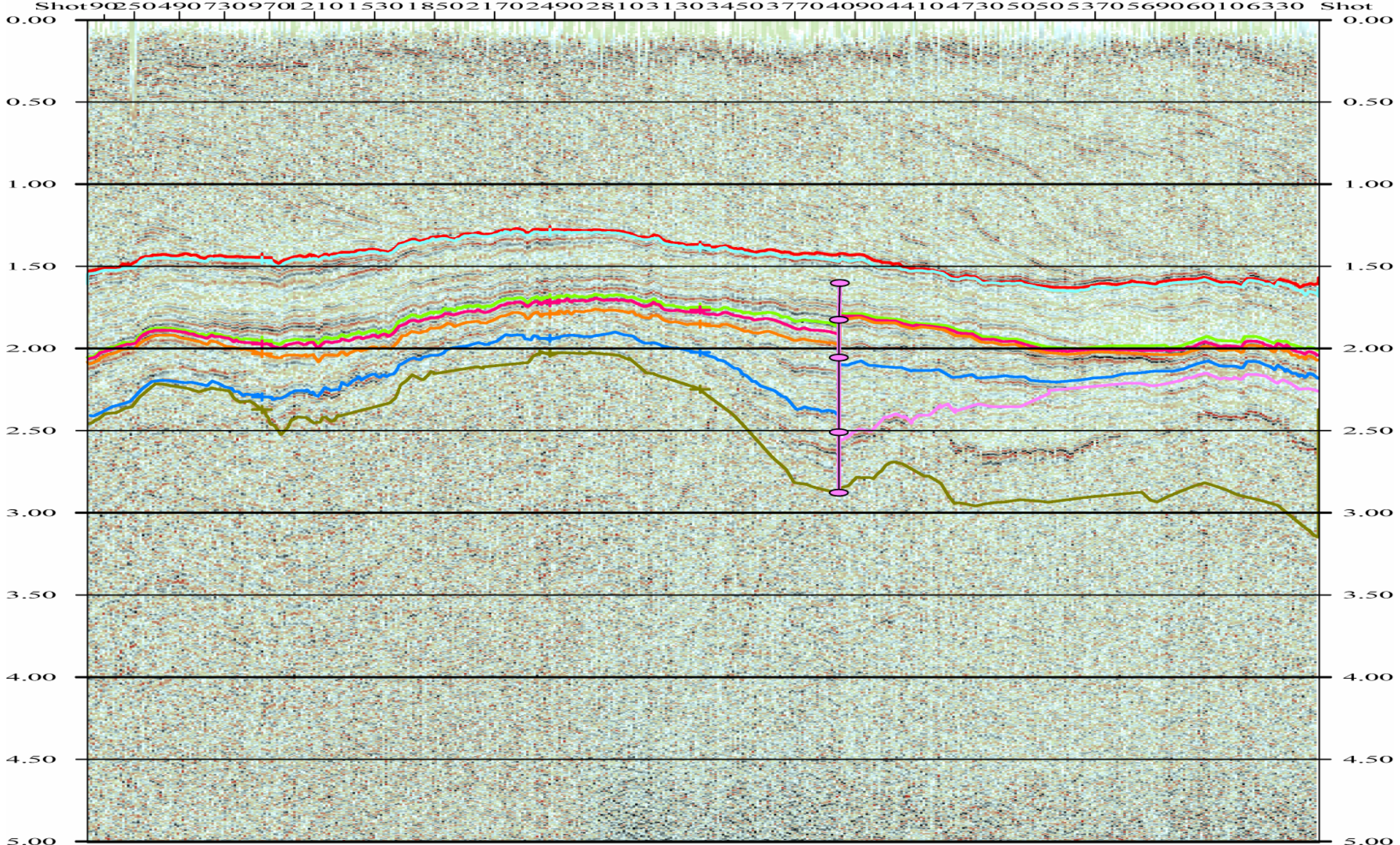

Plate 6 - Seismic Line R-13 (Agena et al, 2000) 
TUNALIK

N-R4-1

N-R5-1 N-RE-1

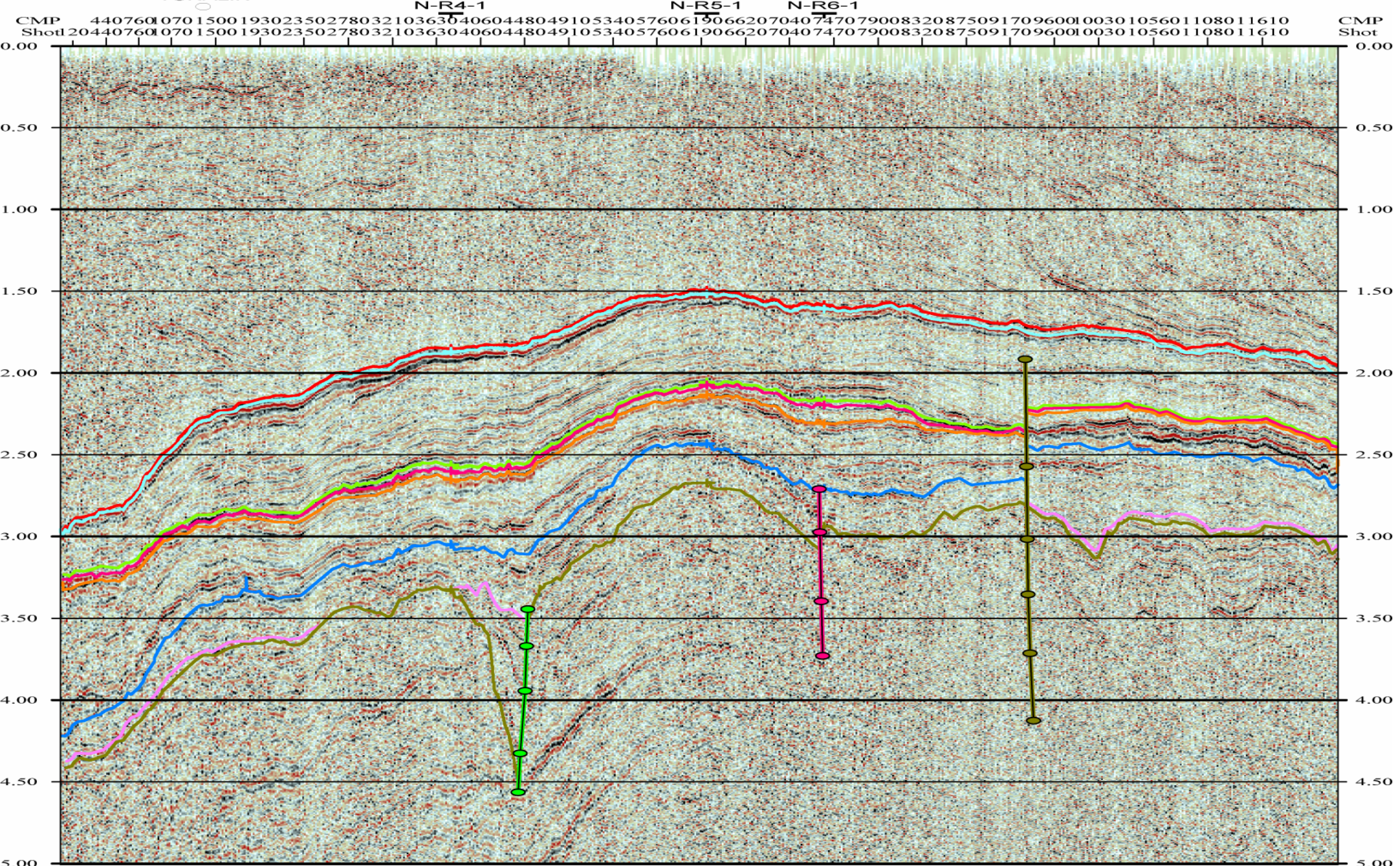

Plate 7 - Seismic Line R-14 (Agena et al, 2000) 


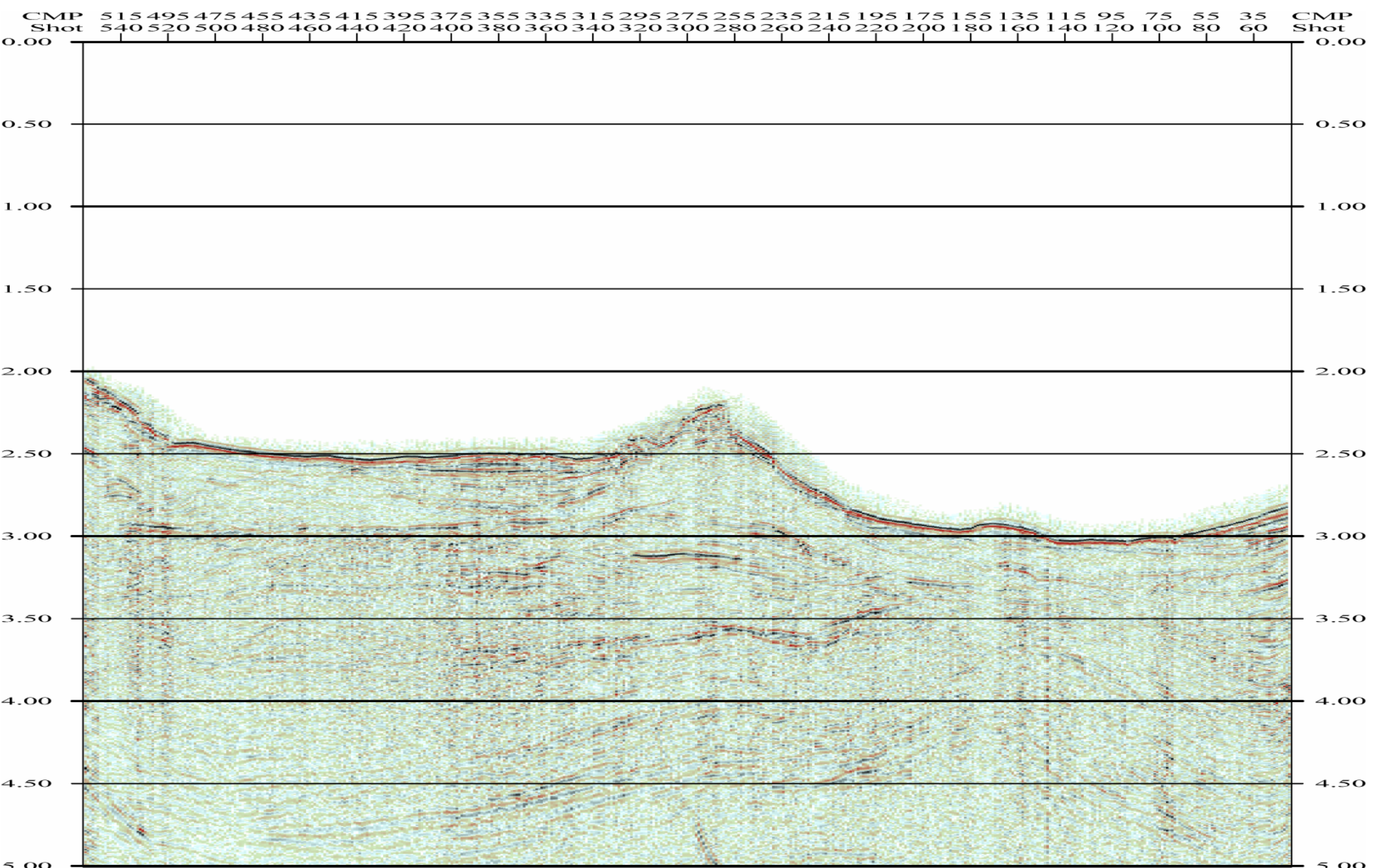

Plate 8 - Seismic Line 770 (Agena et al, 2000) 
CMP 449429409389369349329309289269249229209189169149129109896949 29 CMP

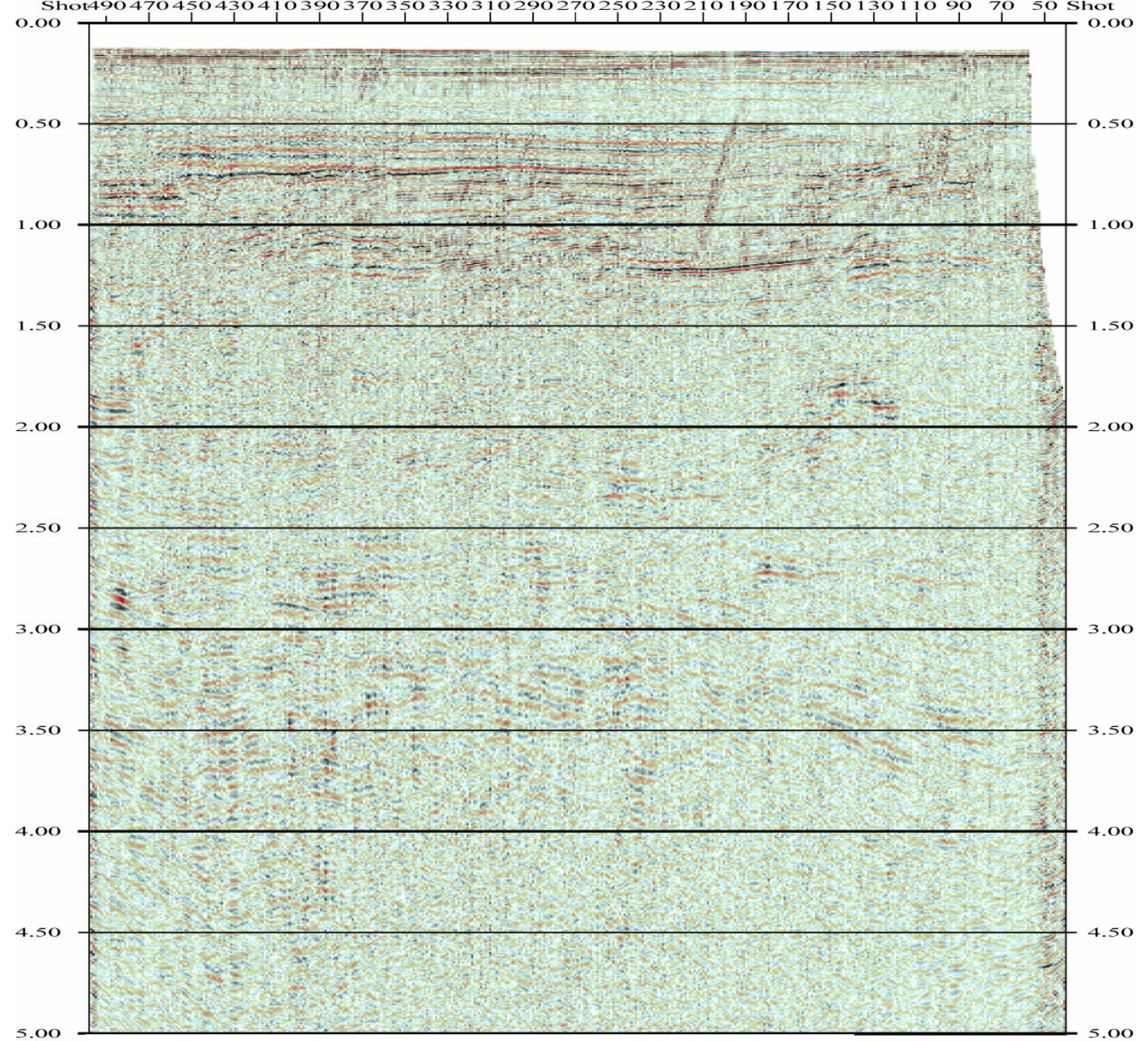

Plate 9 - Seismic Line 772 (Agena et al, 2000) 
T-NPRA778-1

CMP 90150 ' 102703303904505105706306907508108709309901070115012301310 CMP 0.0001801201802403003604204805406004

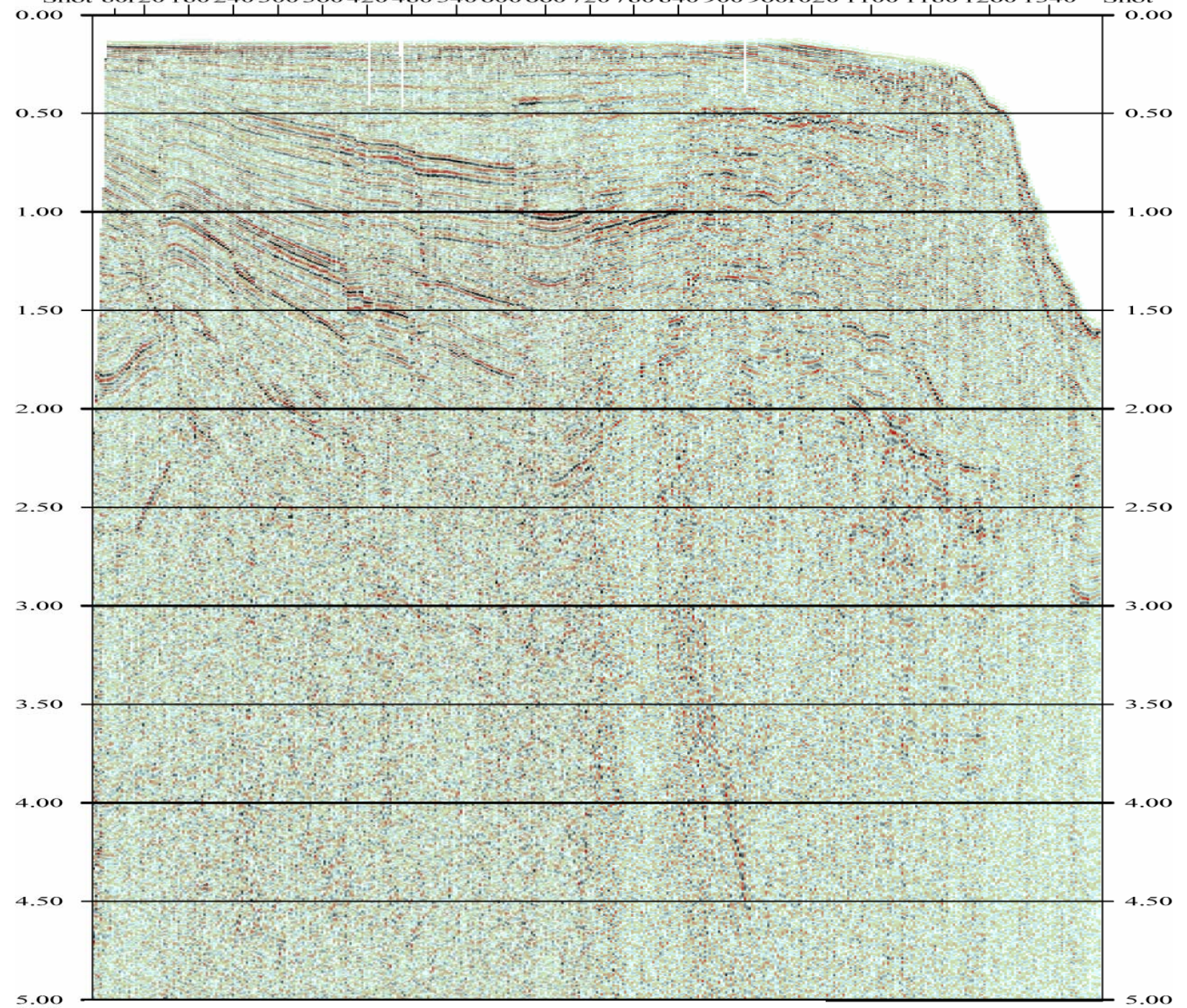

Plate 10 - Seismic Line 773 (Agena et al, 2000) 
T-NPRA778-1

CMP CMP 127111511071991 91185179173167161155149143137131125119113171 CMP

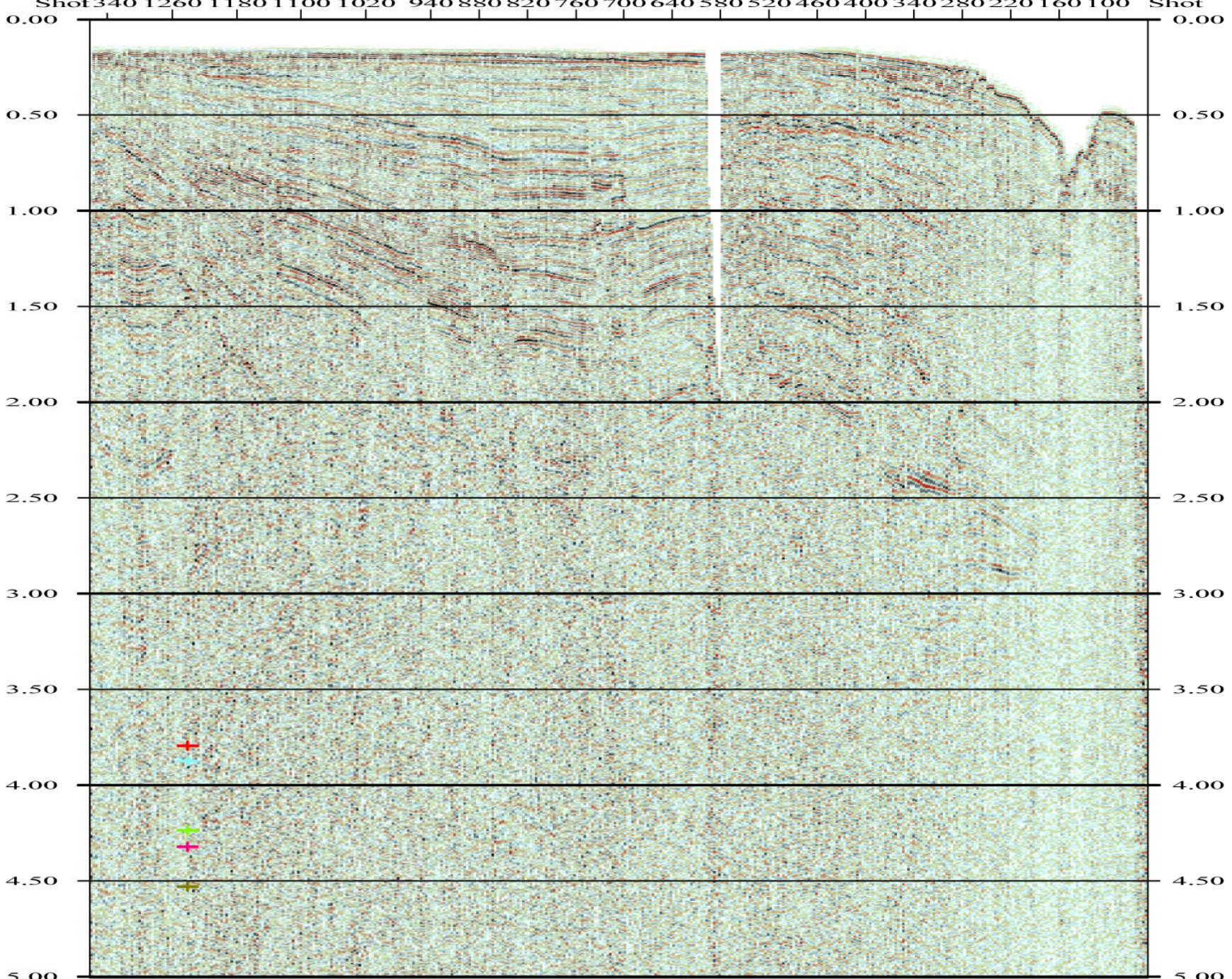

Plate 11 - Seismic Line 774 (Agena et al, 2000) 
T-NPRA778-1

CMP 87081075069063057051045039033027021015090 CMP Shopdosto

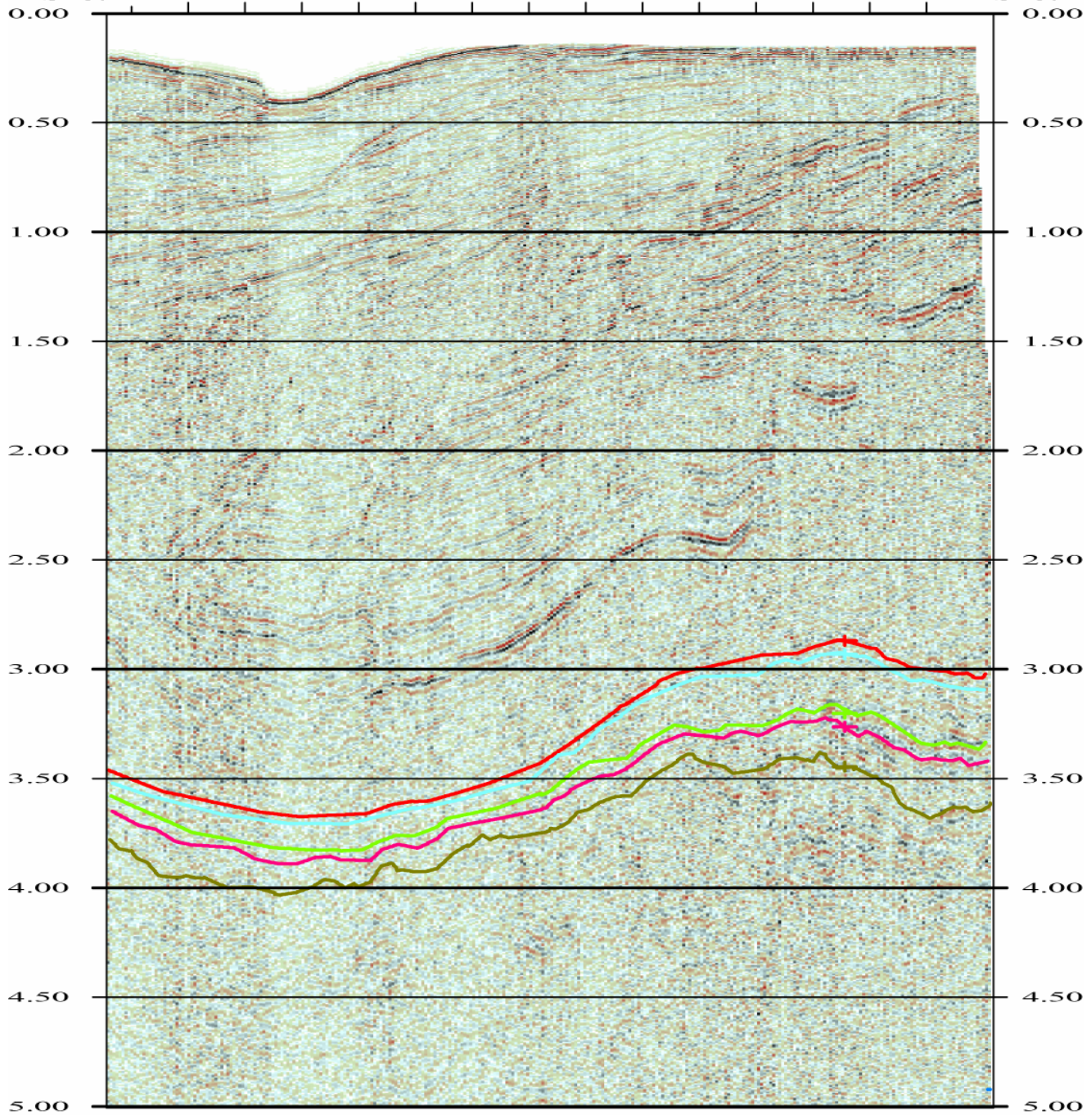

Plate 12 - Seismic Line 775 (Agena et al, 2000) 


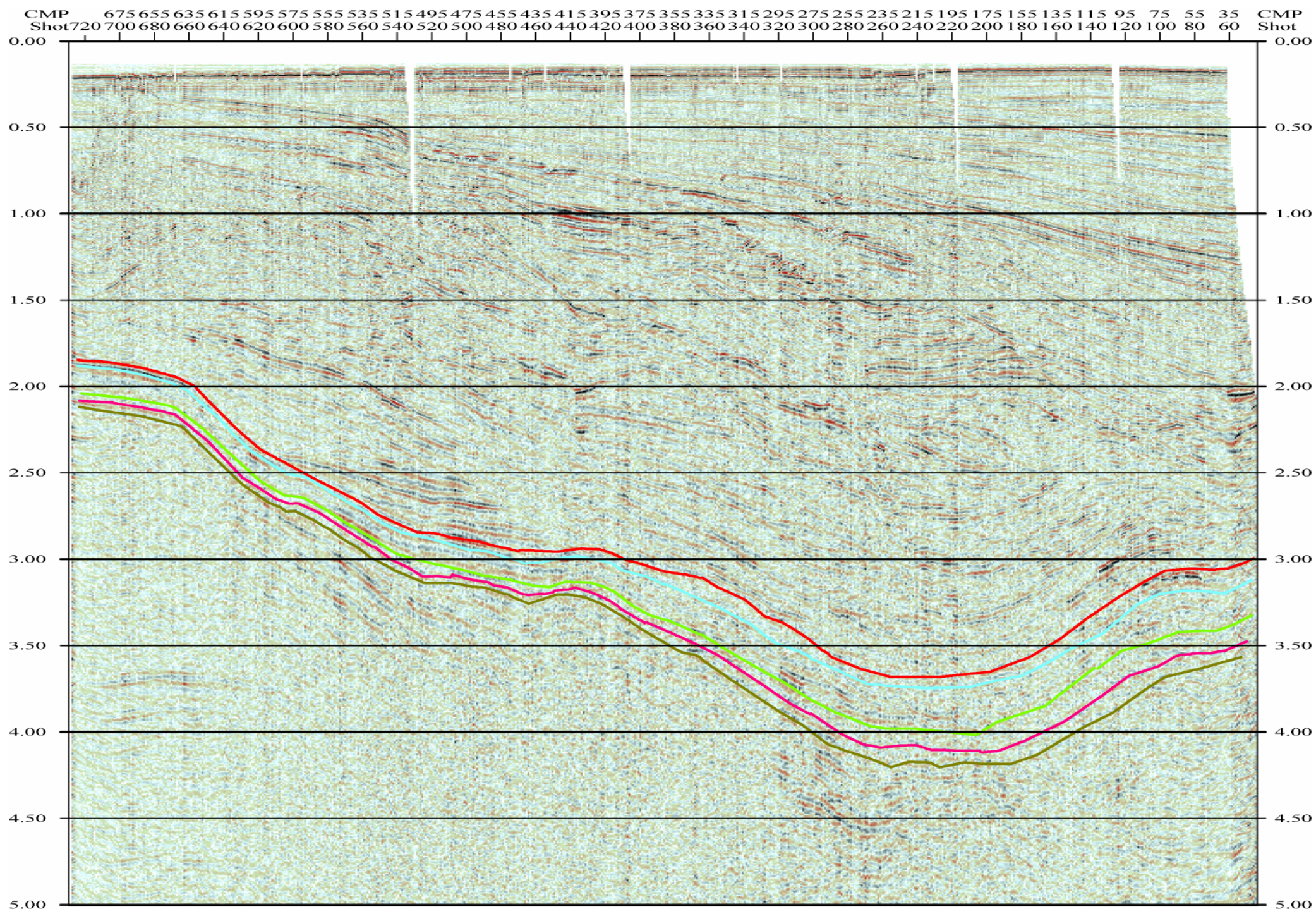

Plate 13 - Seismic Line 776 (Agena et al, 2000) 
T-NPRATMPRATT4NPRA773-1

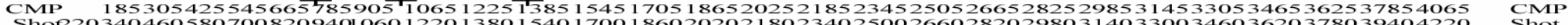

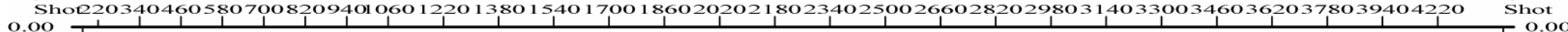

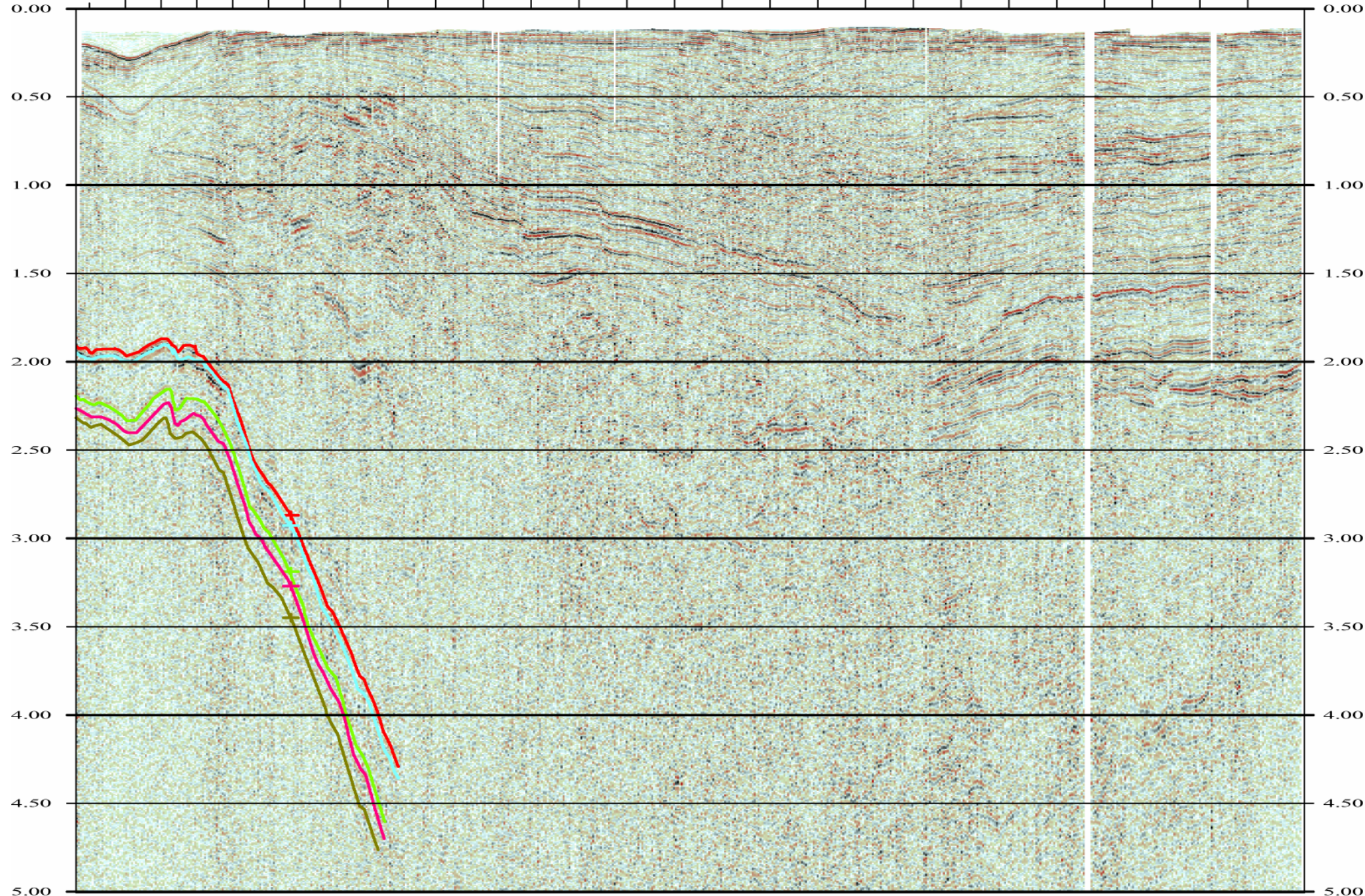

Plate 14 - Seismic Line 778 (Agena et al, 2000) 
PEARD

SKULL CLIFF V-mond

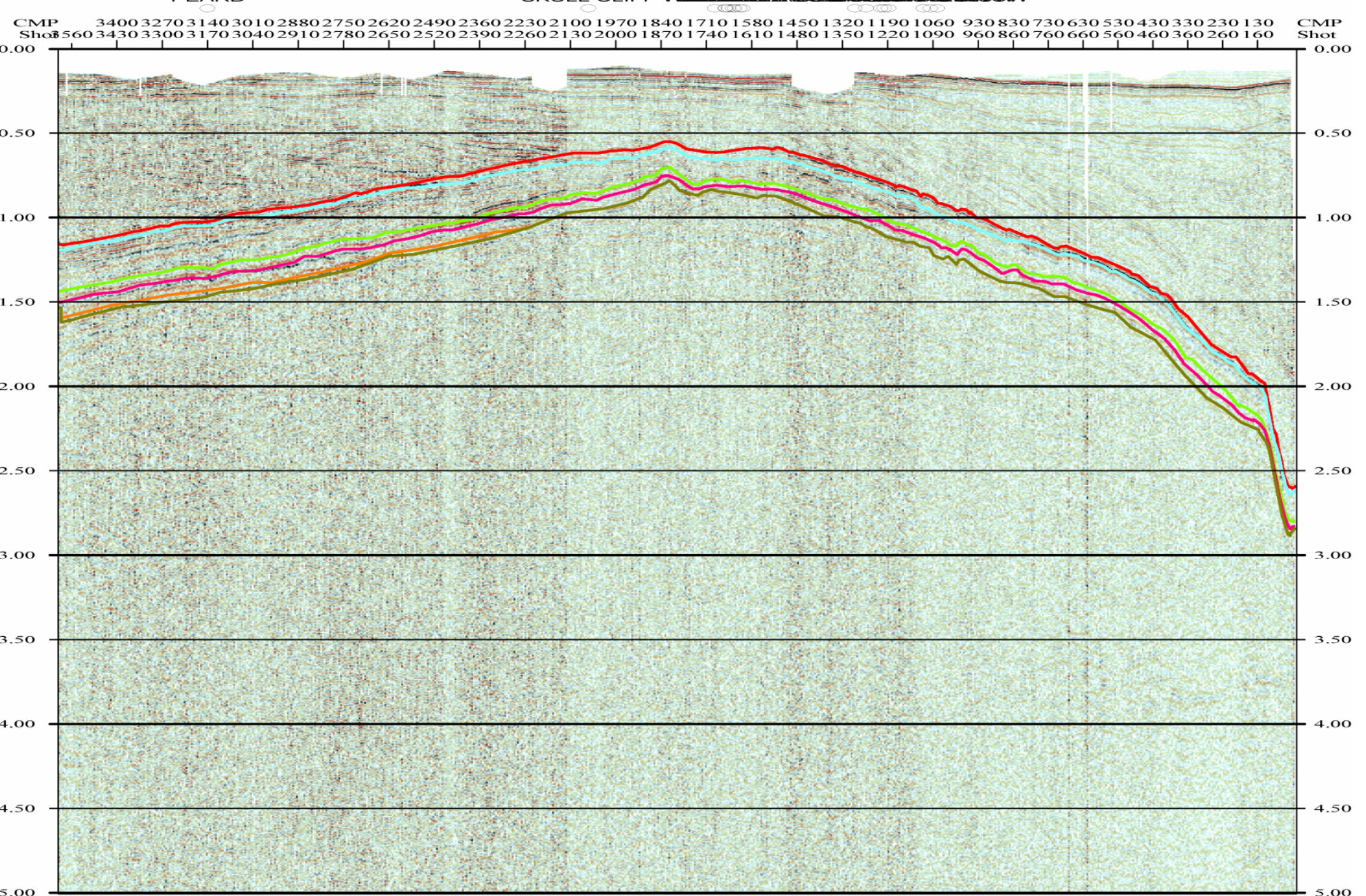

Plate 15 - Seismic Line 780 (Agena et al, 2000) 
T-NPRA783-1

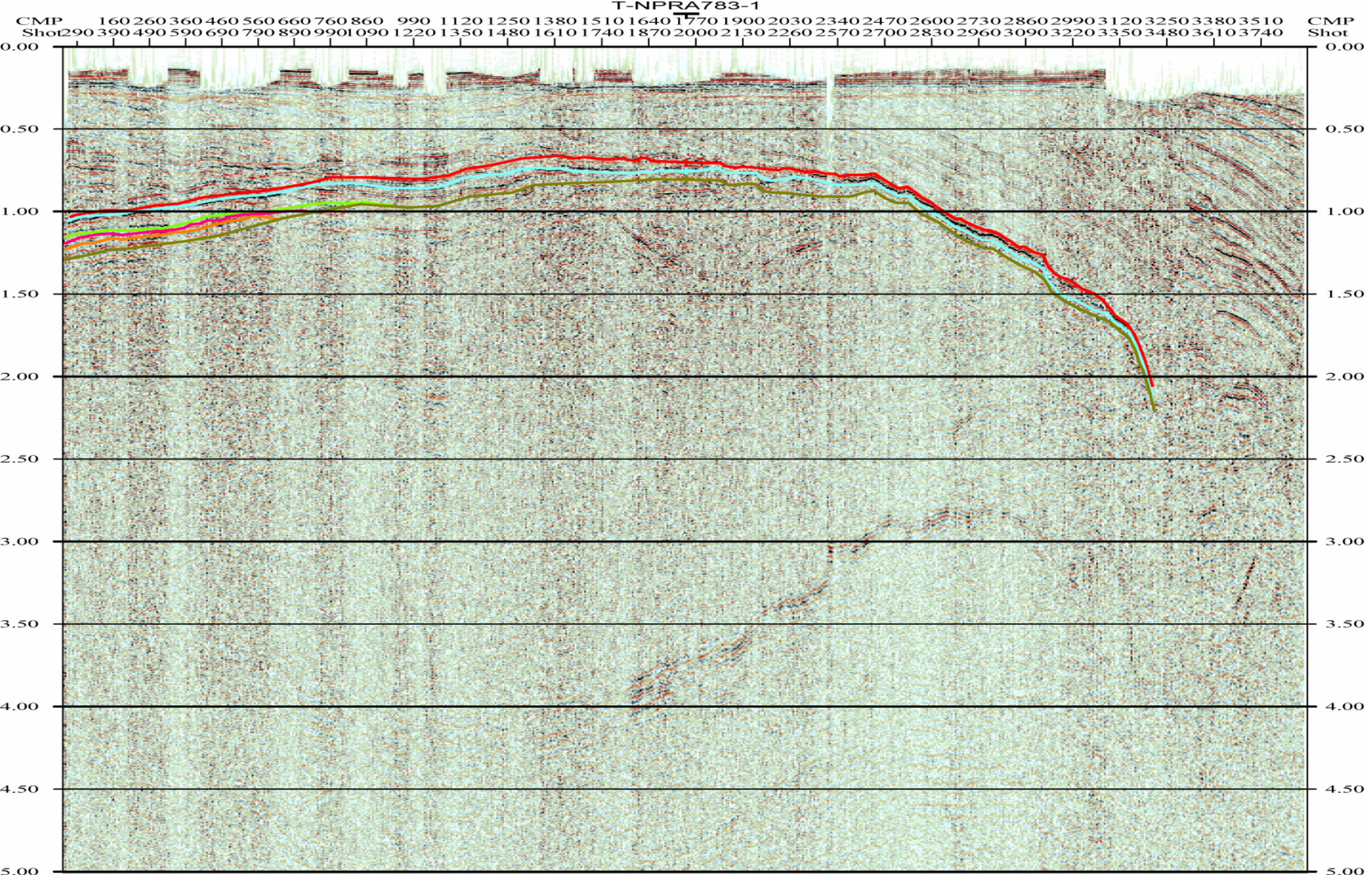

Plate 16 - Seismic Line 781 (Agena et al. 2000) 
T-NPRA783-1

C-804-1C-803-1

CMP

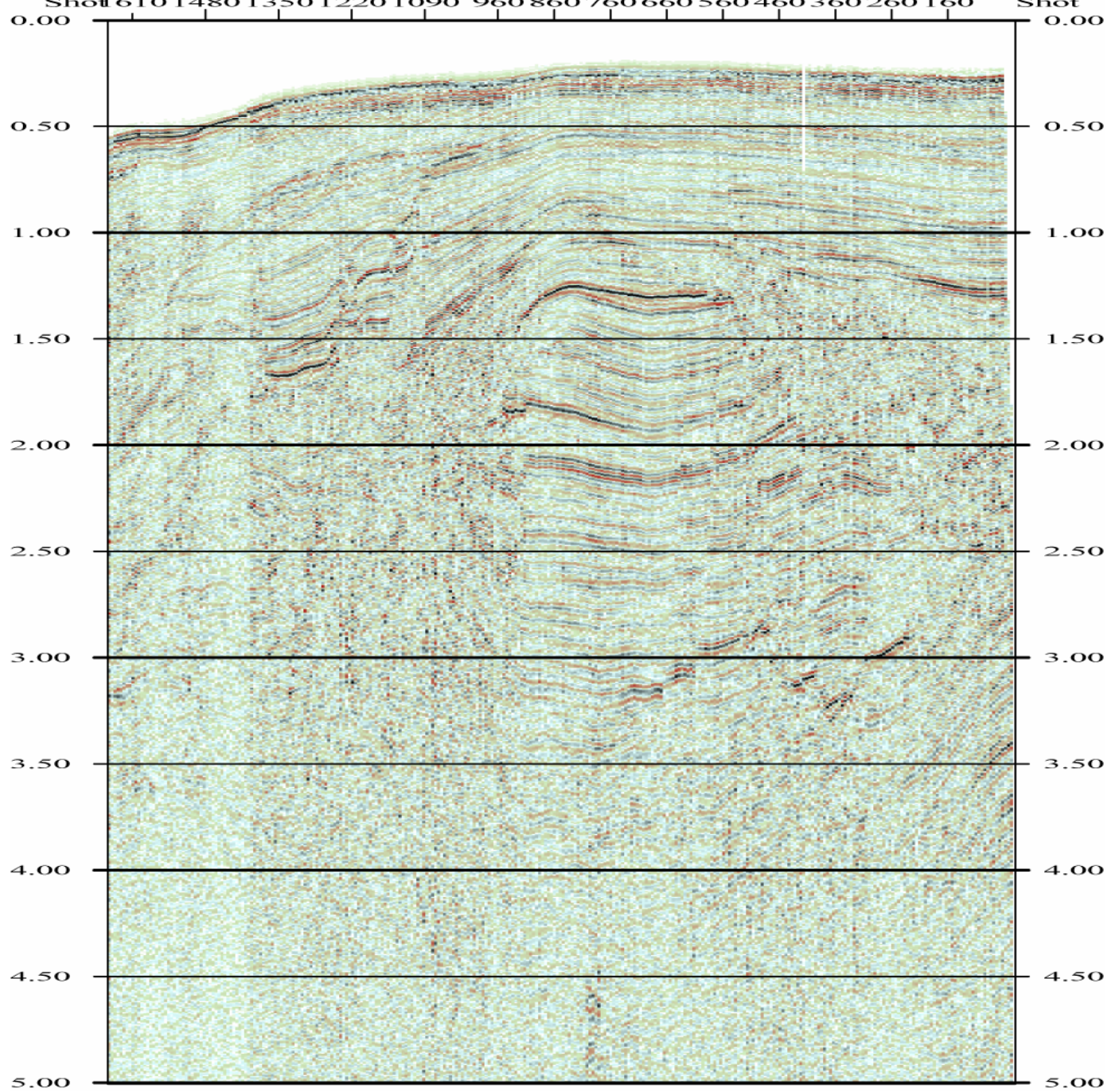

Plate 17 - Seismic Line 782 (Agena et al, 2000) 


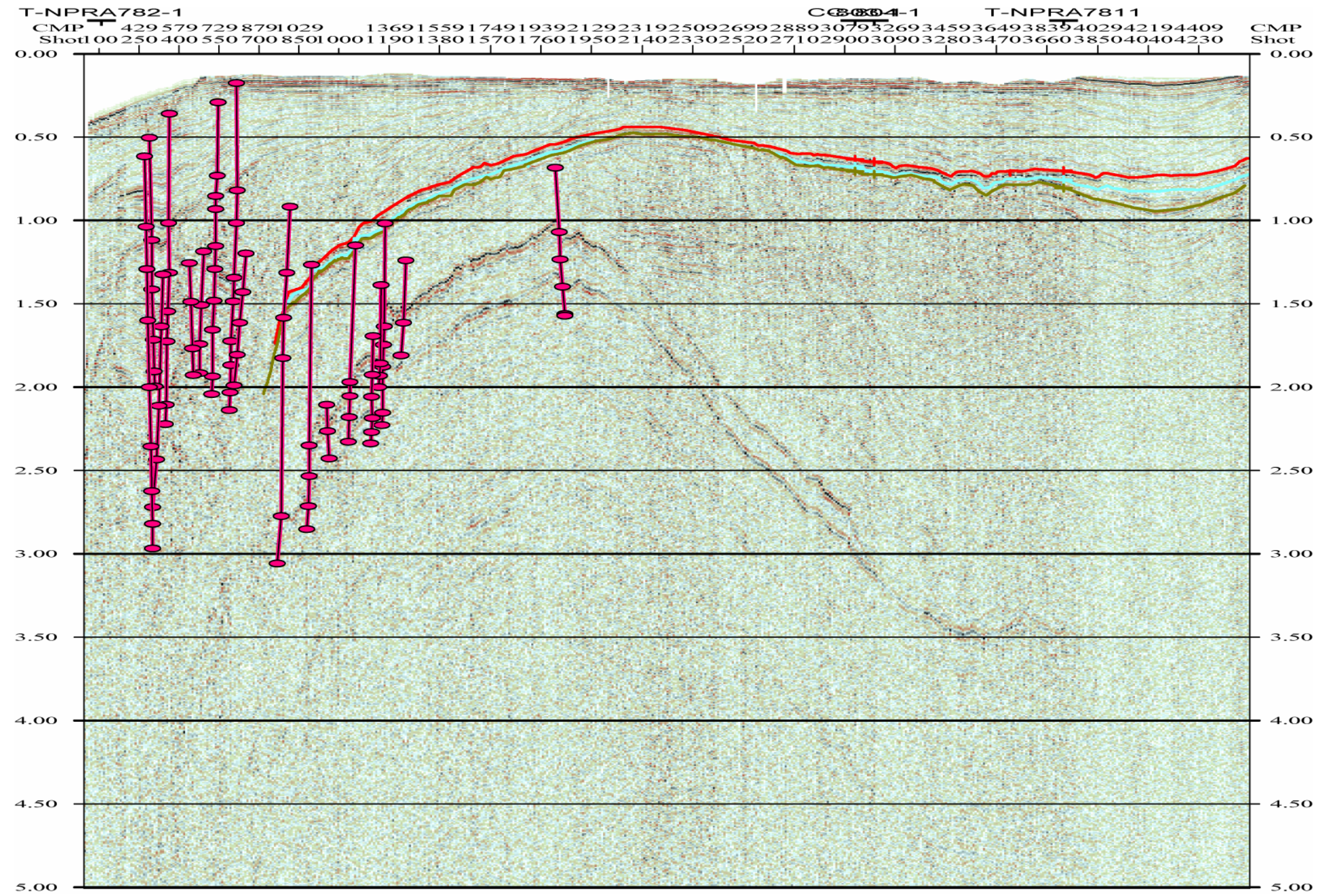

Plate 18 - Seismic Line 783 (Agena et al, 2000) 


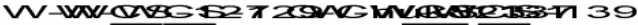

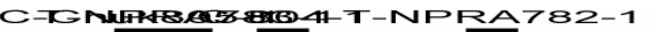

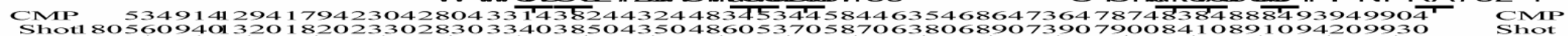

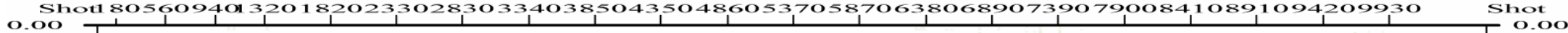

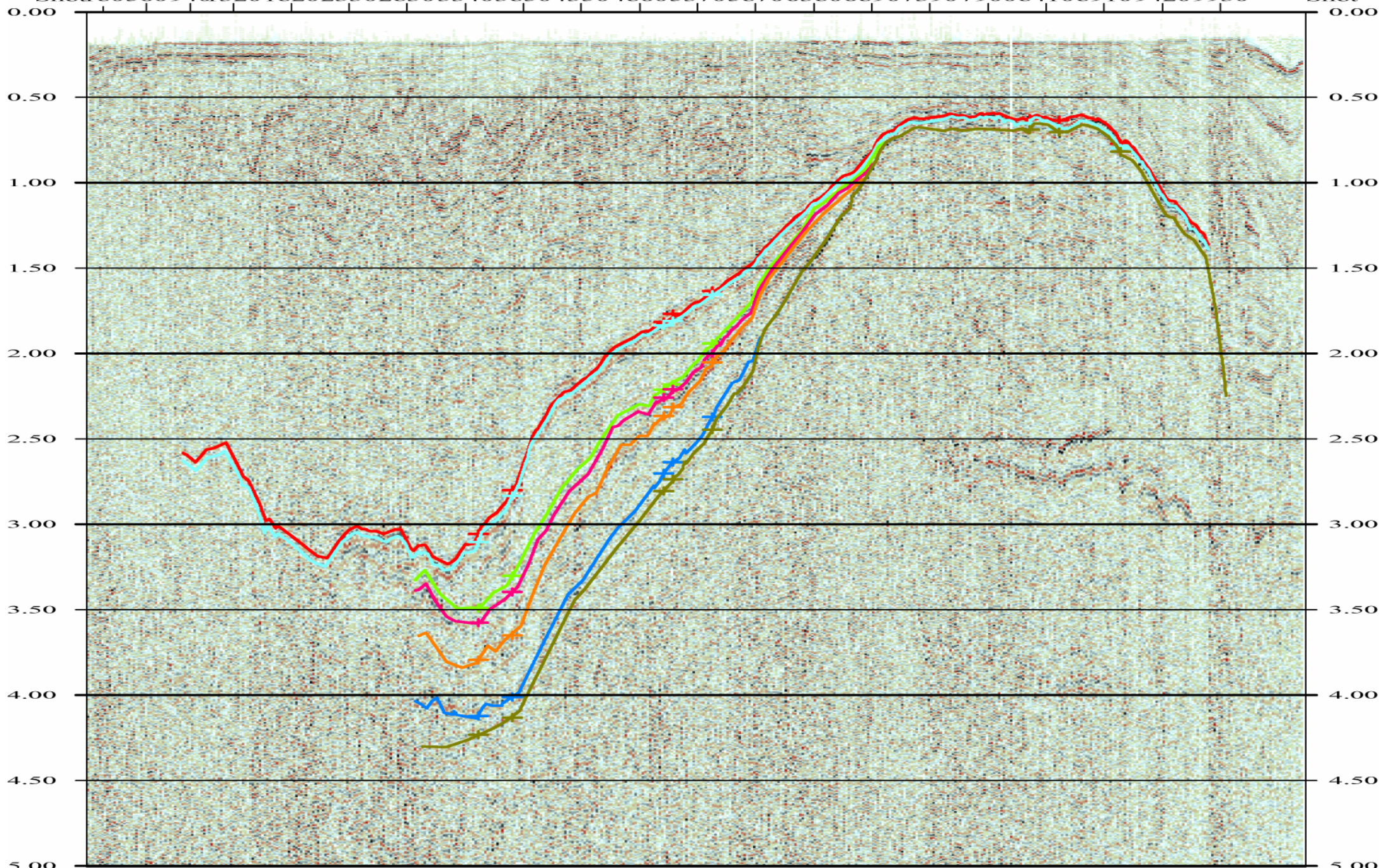

Plate 19 - Seismic Line 803 (Agena et al, 2001) 
T-NPRA783-1 C-803-1 T-NPRA782-1 CMP 1904177416441514138412541124994864764664564464364264164 64 CMP

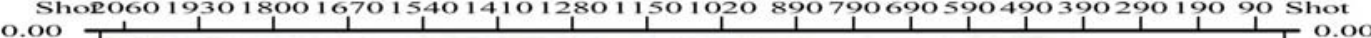

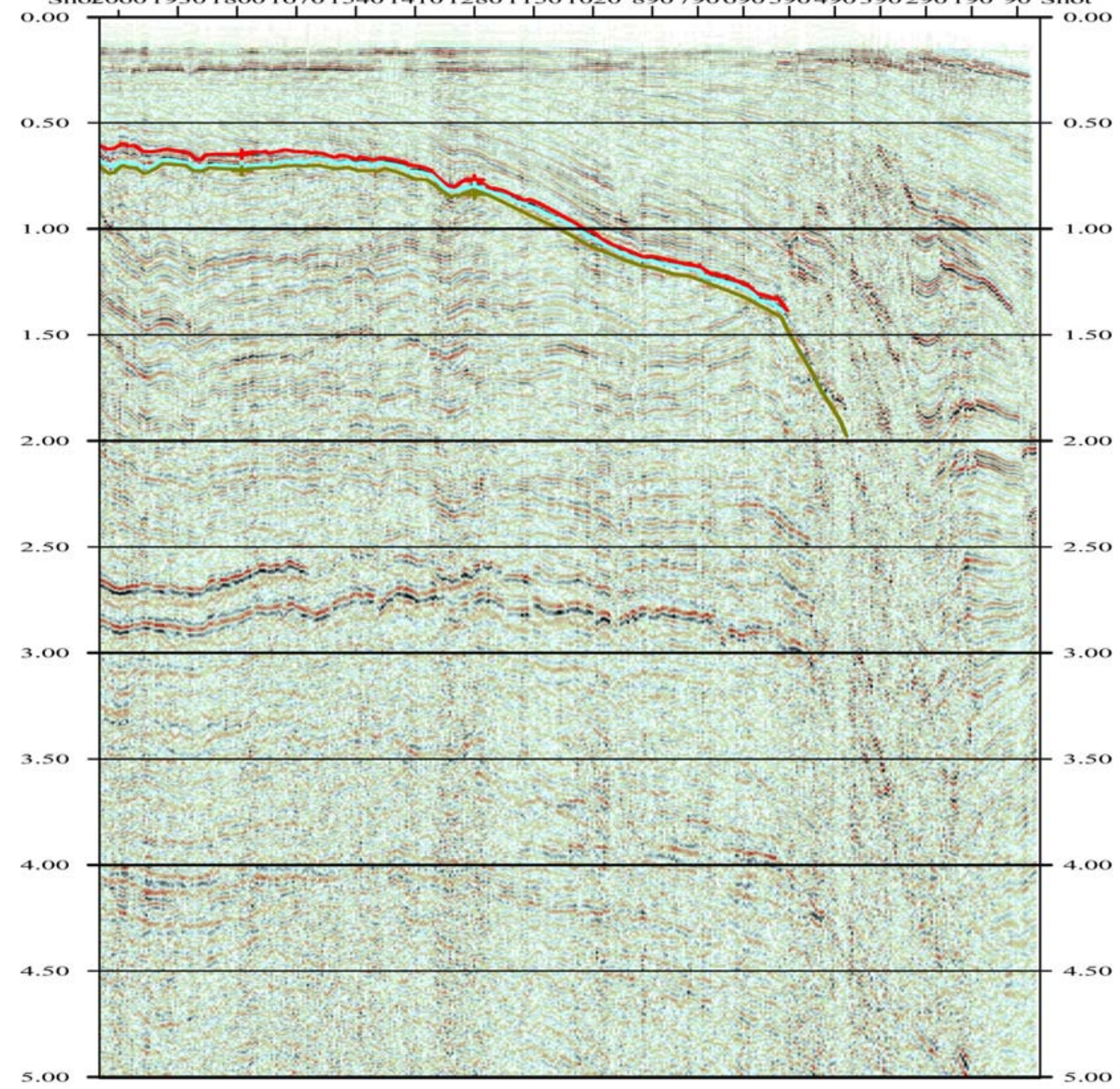

Plate 20 - Seismic Line 804 (Agena et al, 2001) 


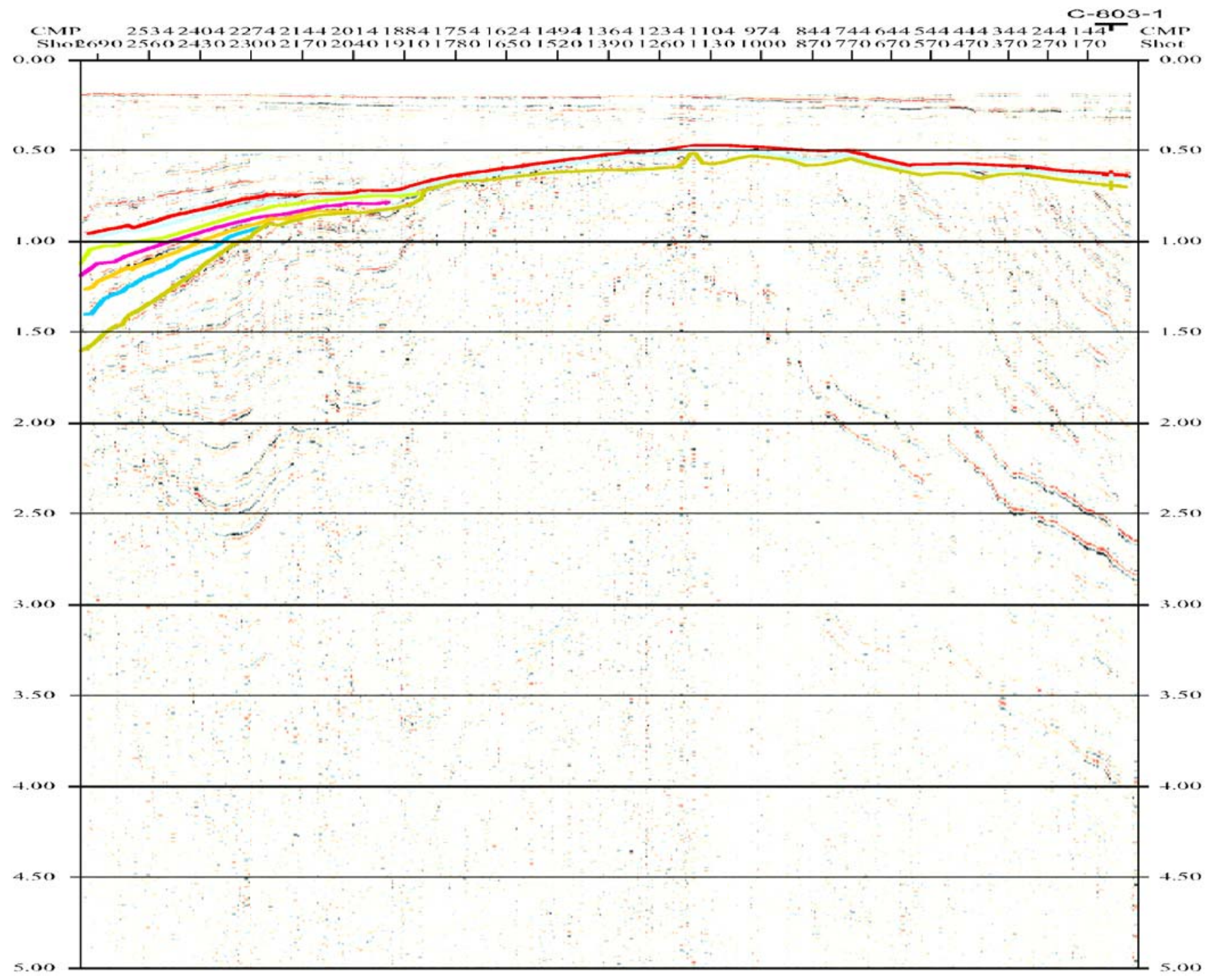

Plate 21 - Seismic Line 805 (Agena et al, 2001) 
W-WCS-12 s-Chuke23-1

C-Chuka20-1

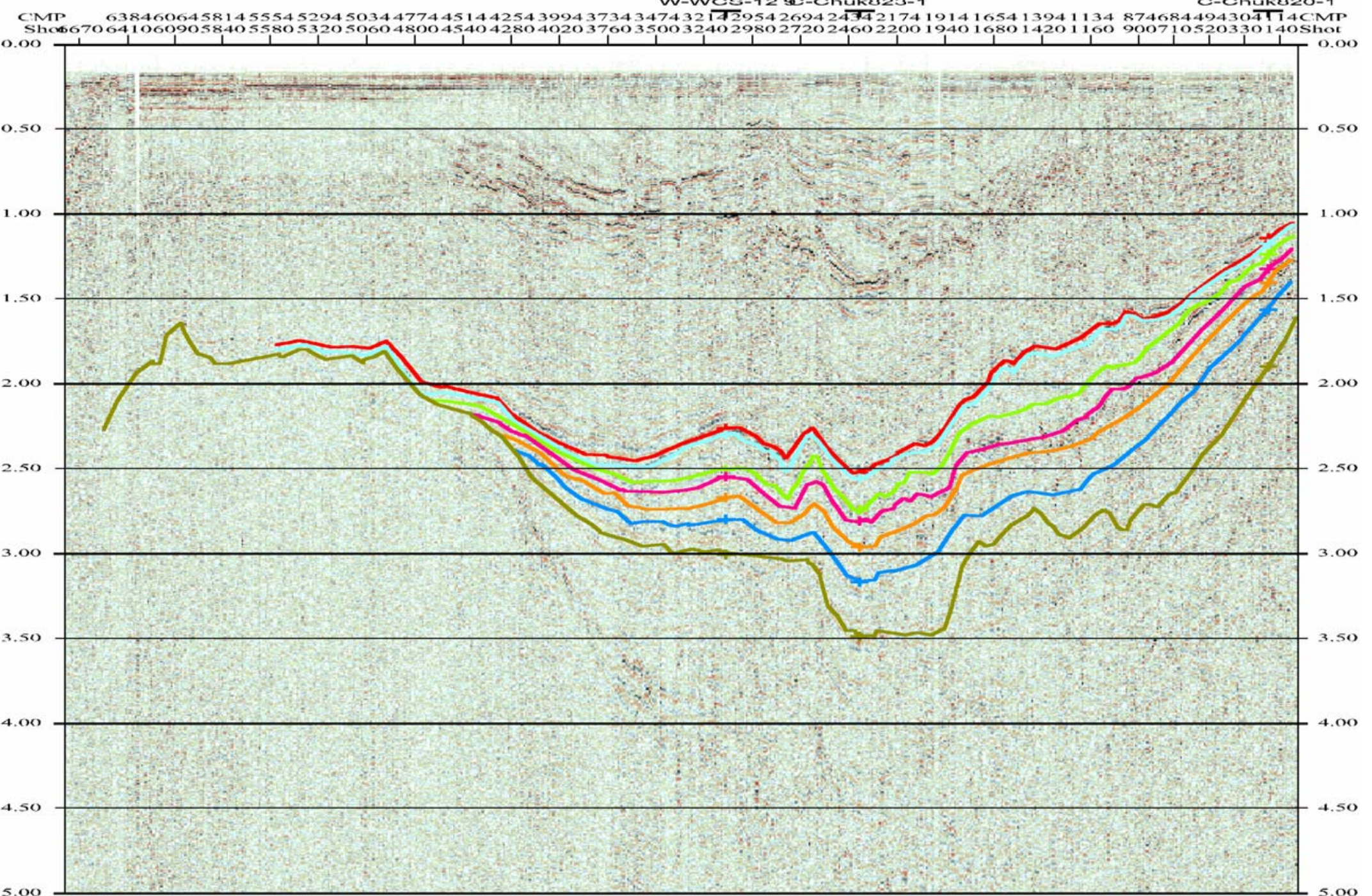

Plate 22 - Seismic Line 806 (Agena et al, 2001) 
C-Chuk823-1

C-Chuk820-1

C-Chuk809-1

CMP 27446465484403412841544180420642324258428443104336436243884414444044664492451845444570459646224648467447004 CMP Shot1 $10300490680870106013101570183020902350261028703130339036503910417044304690495052105470573059906250651067707030 \quad 5 h 0 t$

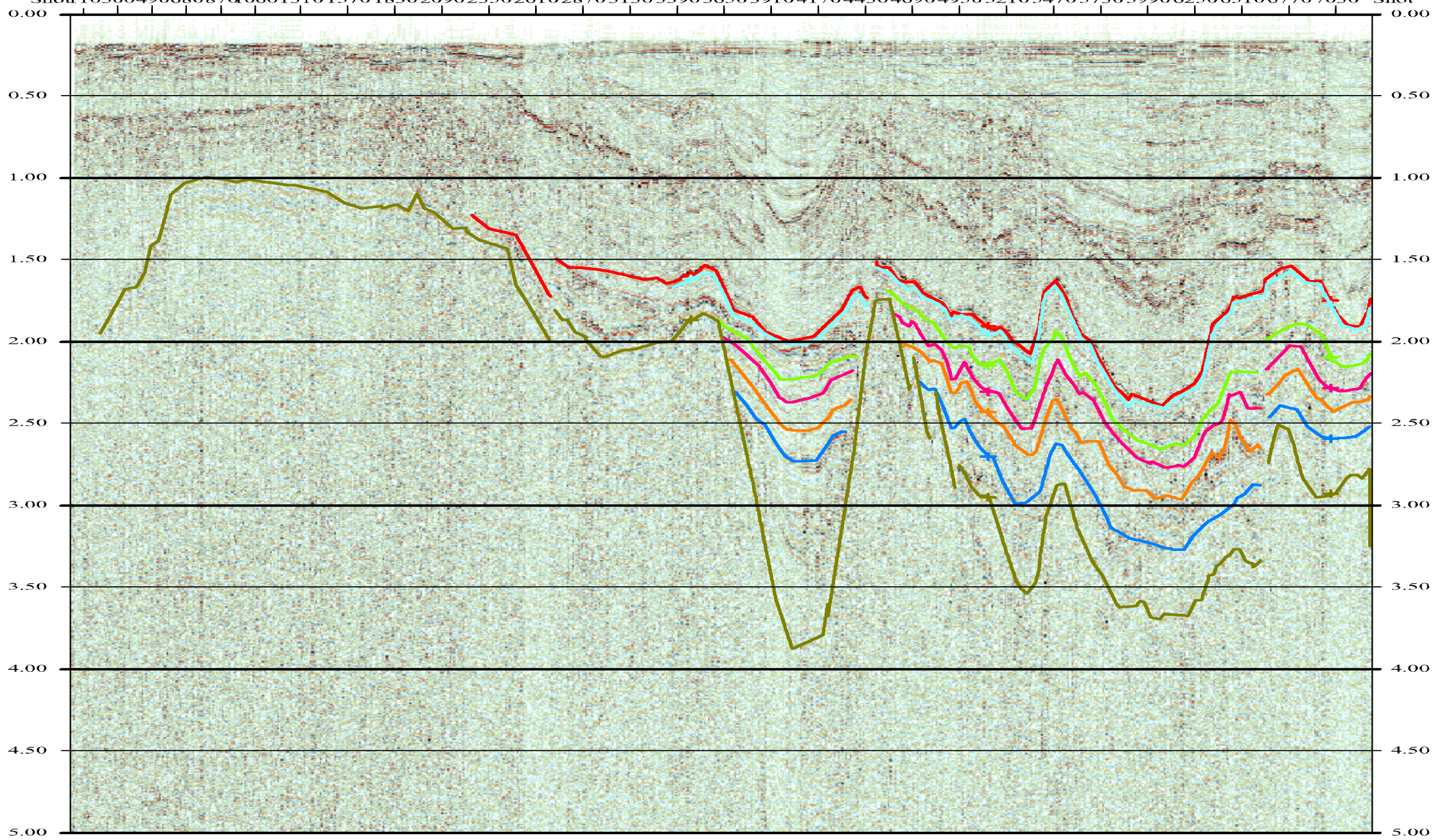

Plate 23 - Seismic Line 808 (Agena et al, 2001) 
C-Chuk819-1 C-Chuk819-1 C-Chuk808-1 CMP T1704 1604 1504 1404 130412041104100490482475467460452445437430422415474\% CMP

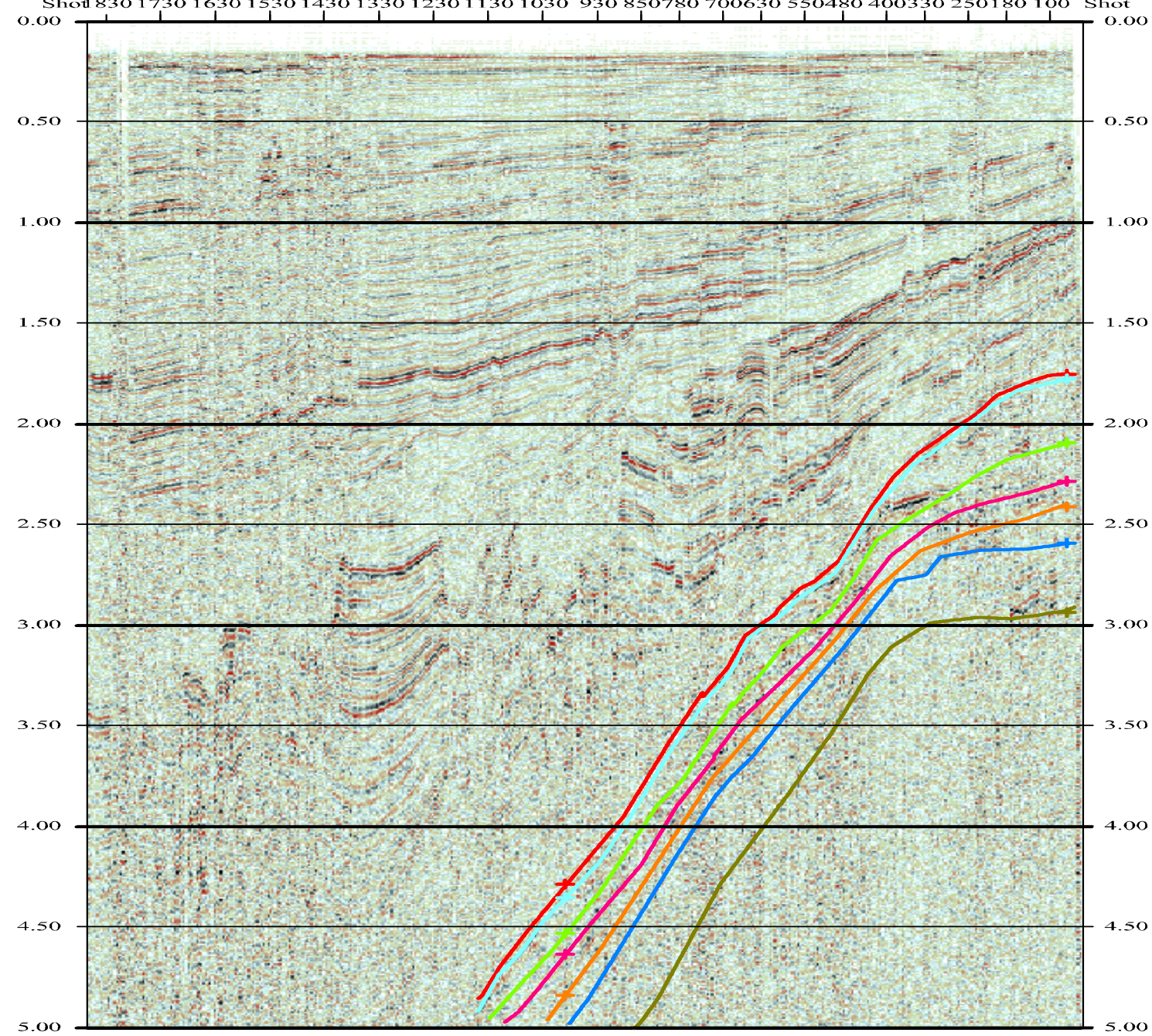

Plate 24 - Seismic Line 809 (Agena et al, 2001) 
B

C-Chuk819-1

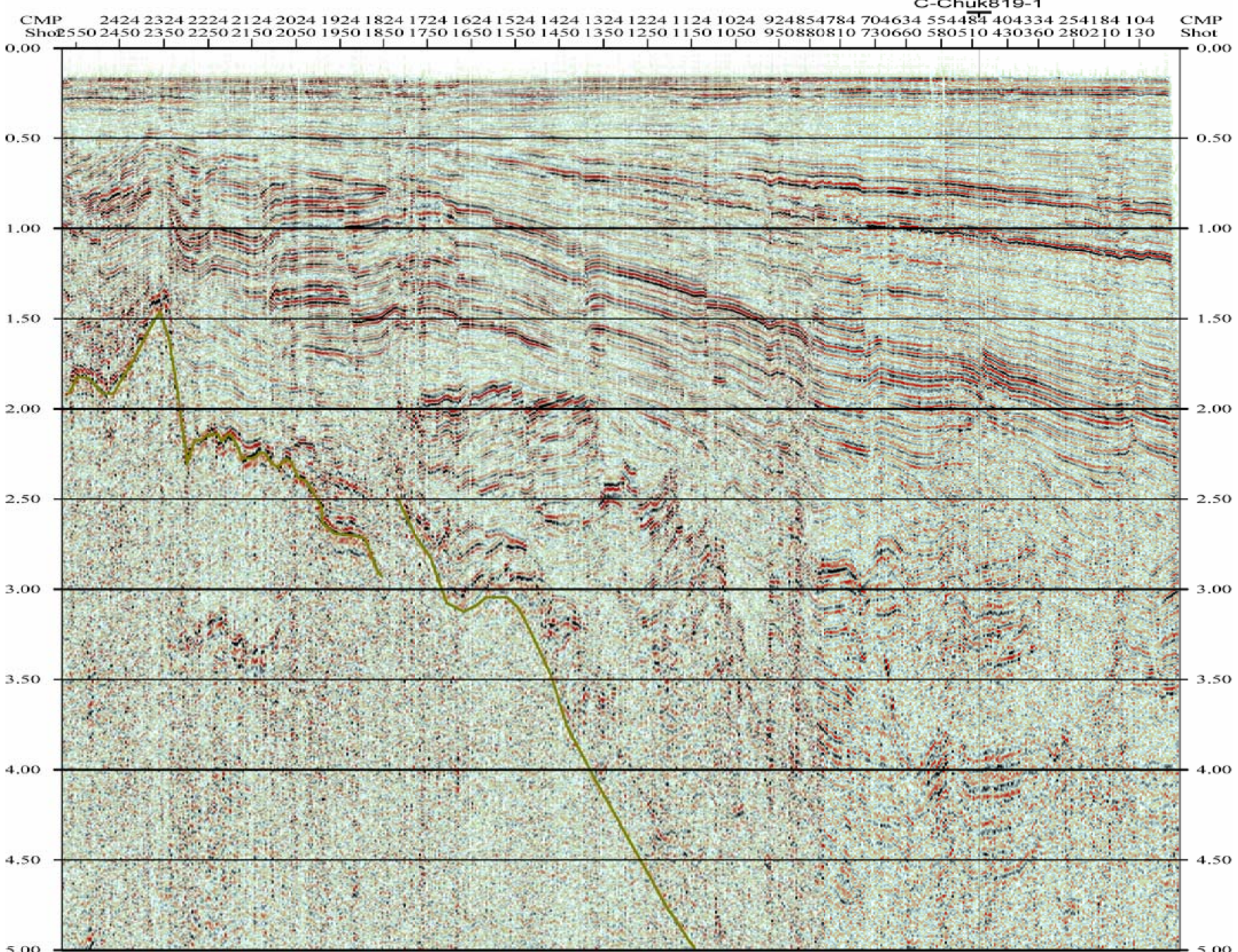

Plate 25 - Seismic Line 811 (Agena et al, 2001) 
C-Chuk8C-1Chuk809-1C-Chuk809-1 CMP 29449469499412541514177420342294255428143074333435943854411443744634489451545414567455346194664546714697475347494
Shotl 203205207201020128015401800206023202580284031003360362038804140440046604920518054405700596062064806740700072607520 CMP o. Oo

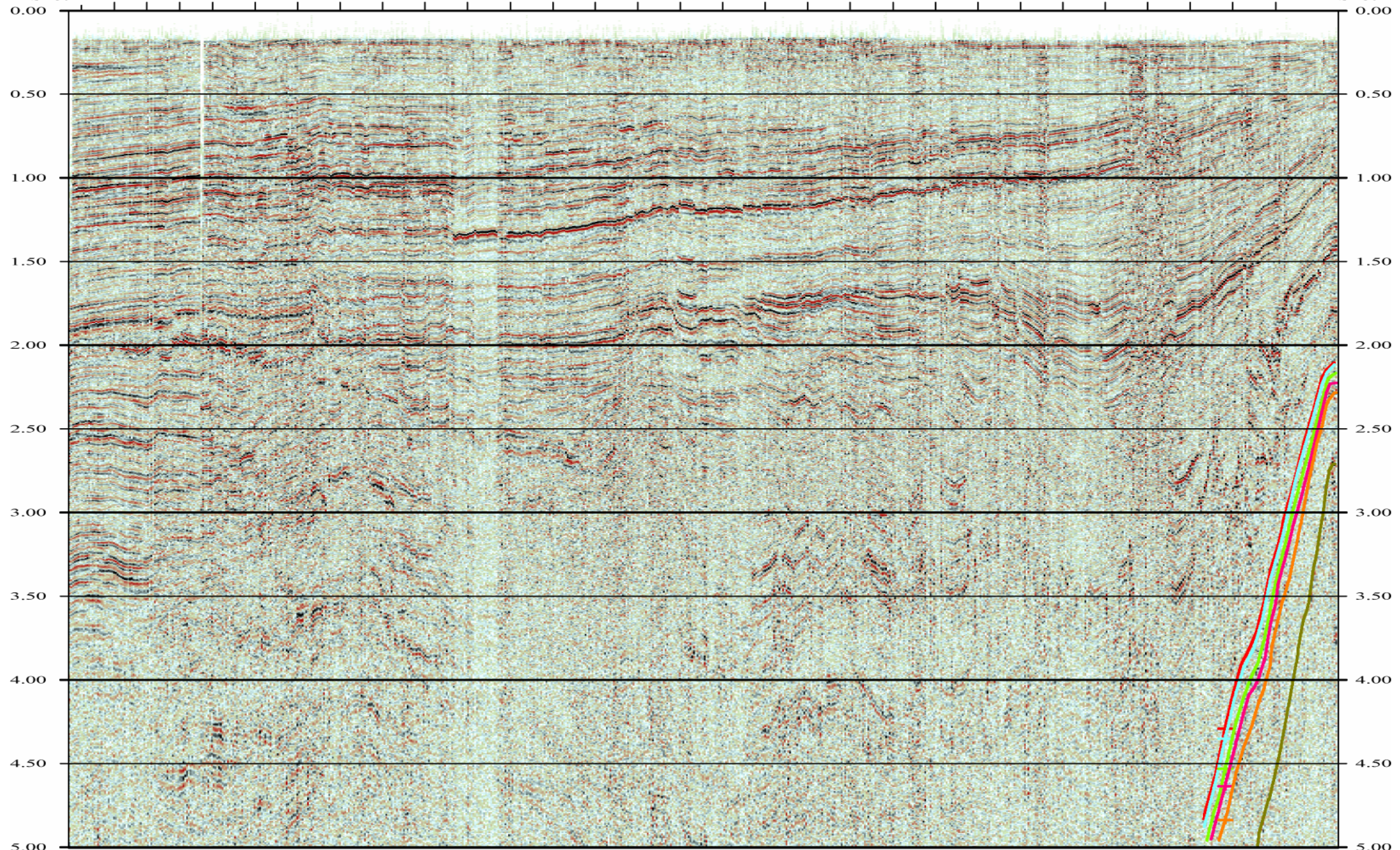

Plate 26 - Seismic Line 819 (Agena et al, 2001) 


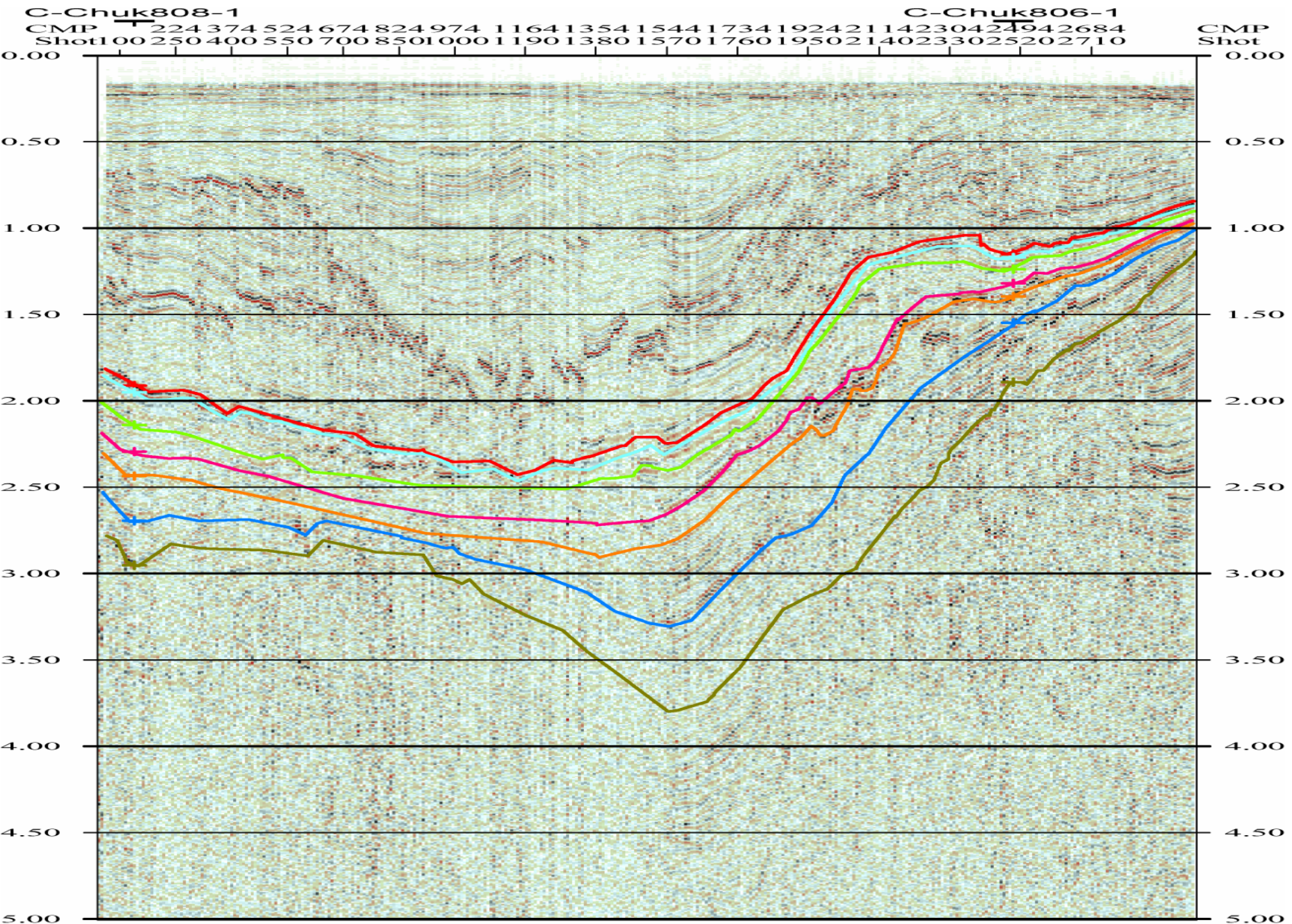

Plate 27 - Seismic Line 820 (Agena et al, 2001) 


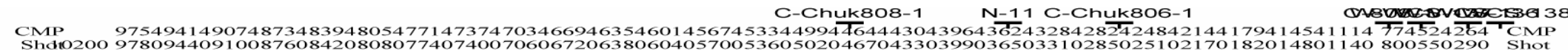

A

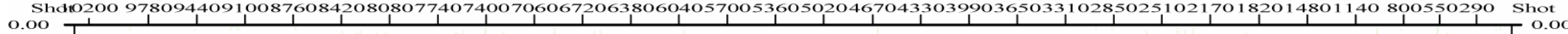

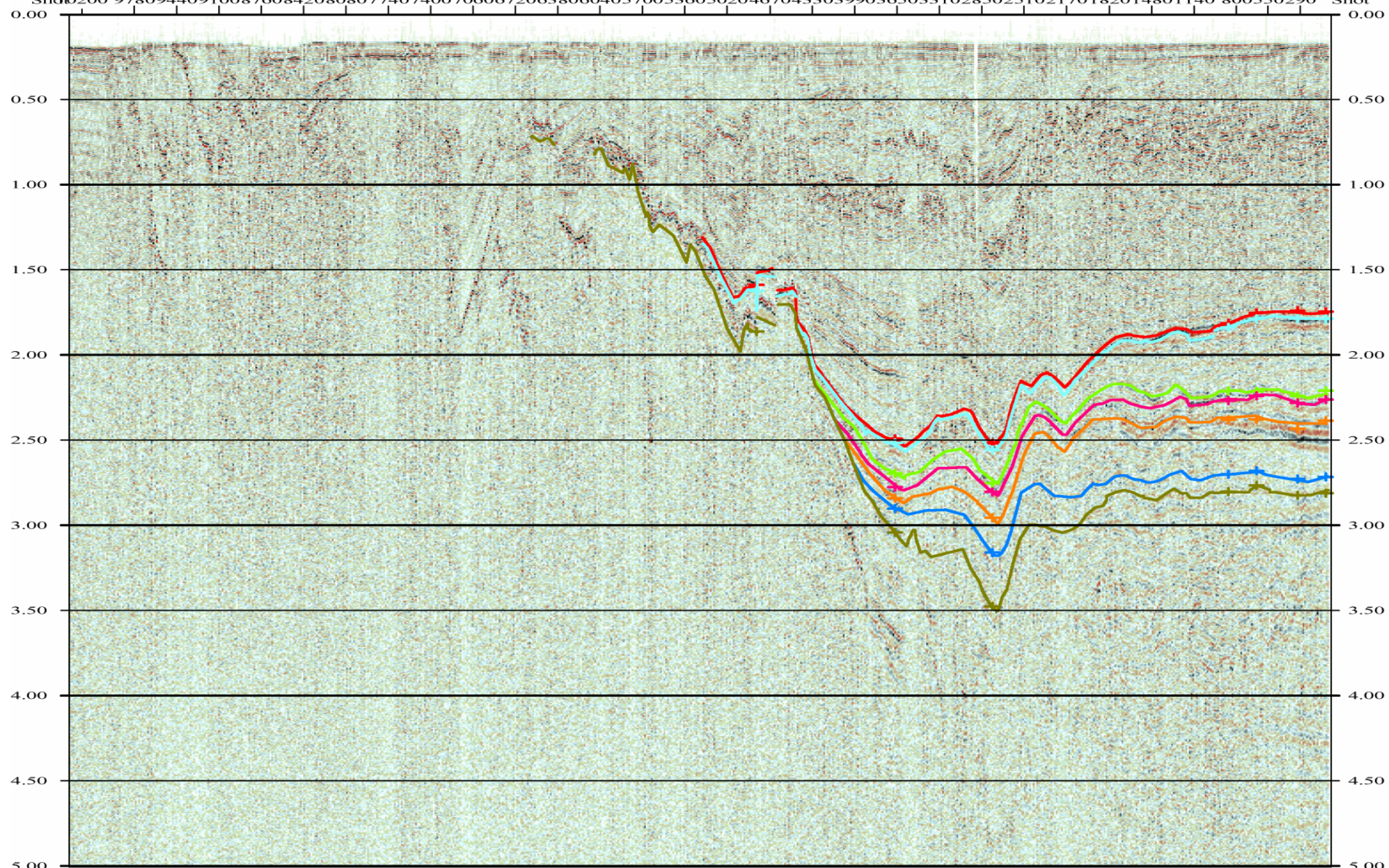

Plate 28 - Seismic Line 823 (Agena et al, 2001) 


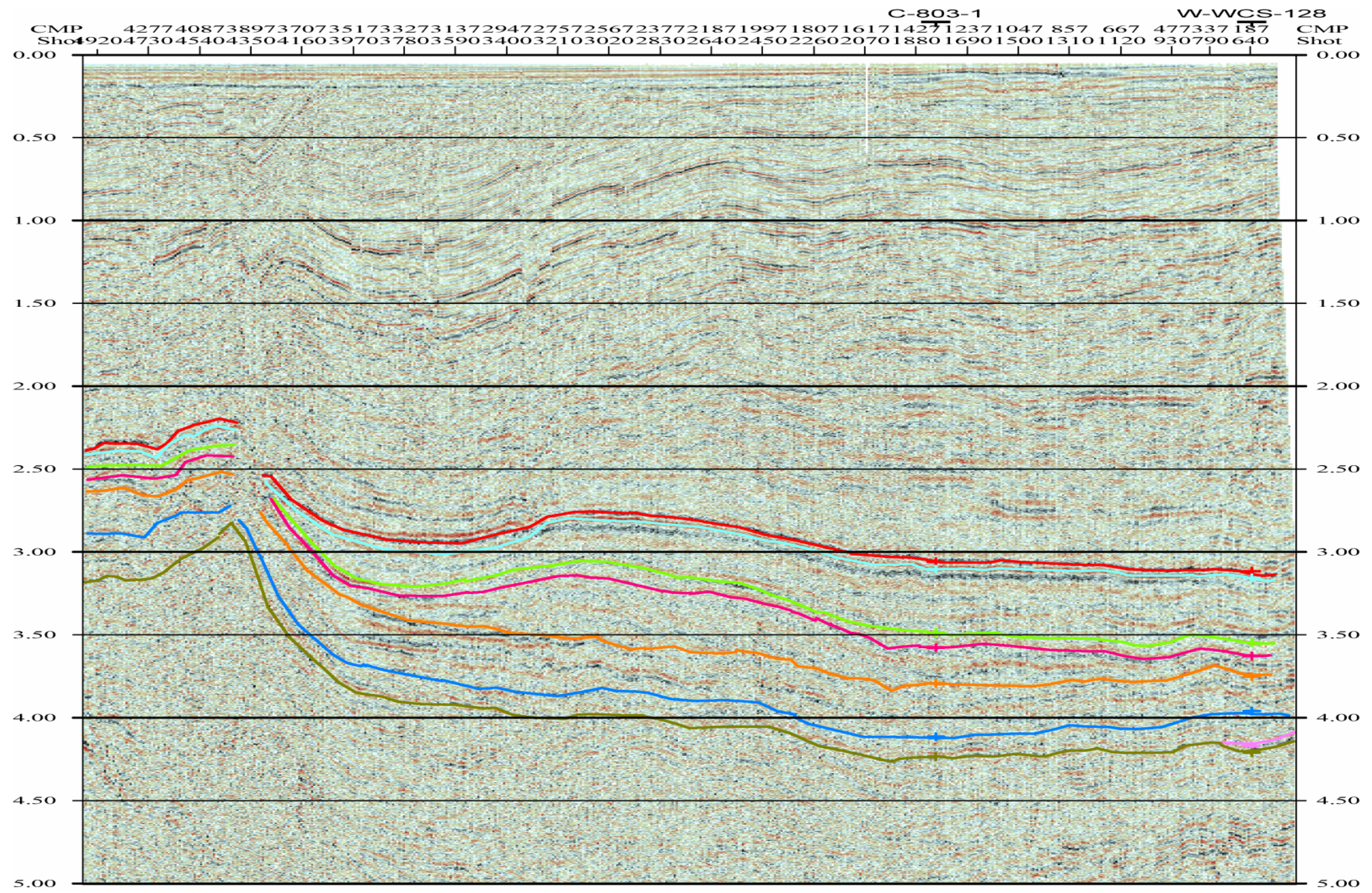

Plate 29 - Seismic Line 127 (NAMSS, 2004) 
W-WCS-NATWCS-129

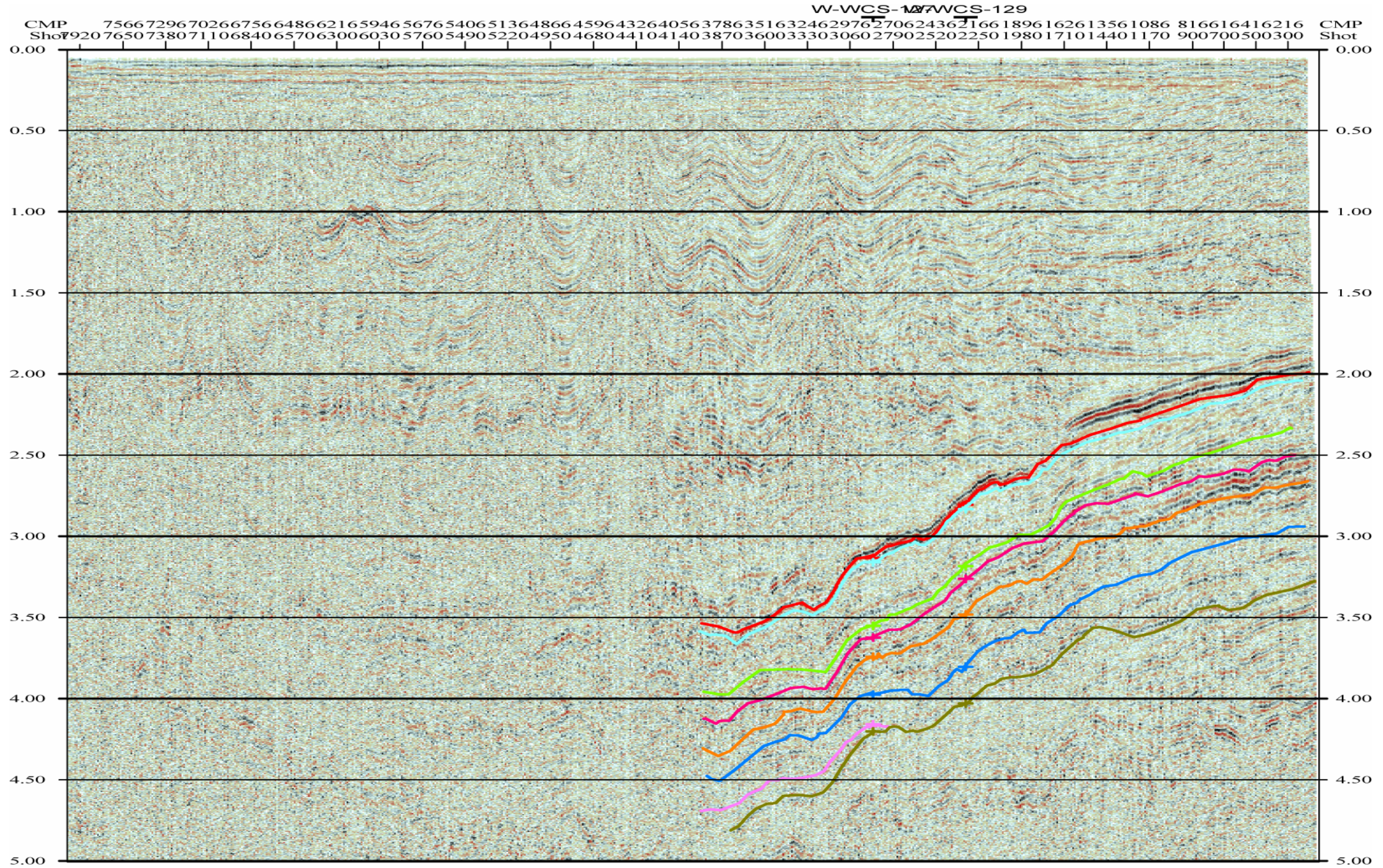

Plate 30 - Seismic Line 128 (NAMSS, 2004) 
C-Chuk806-1

C-803-1

W-WCS-128

CMP 2664566468361026121614061596178619762166235625462736292631163306349636863876406642564446 4736 CMP

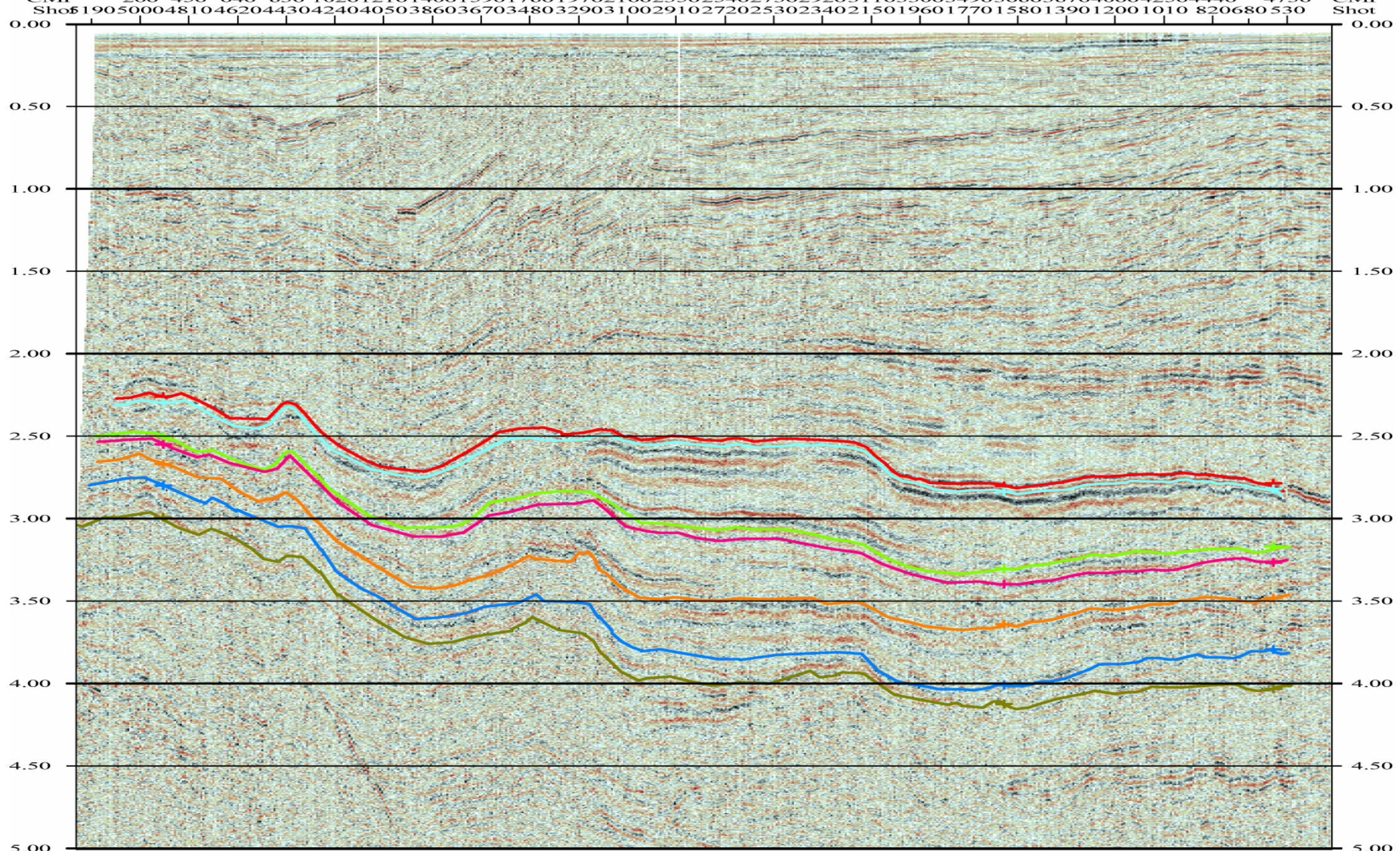

Plate 31 - Seismic Line 129 (NAMSS, 2004) 


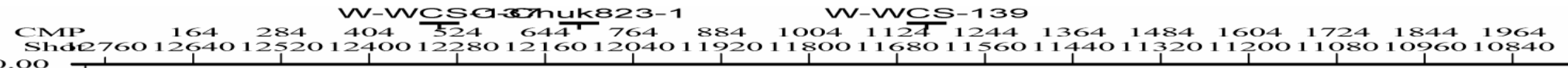

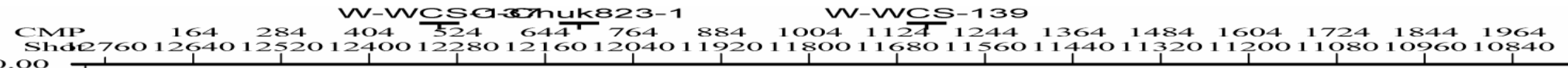

SMot

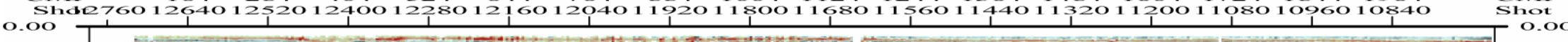

0.50

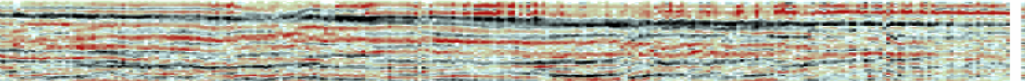

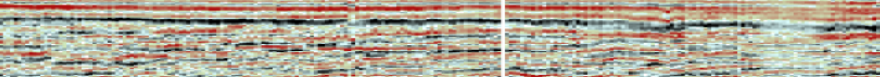

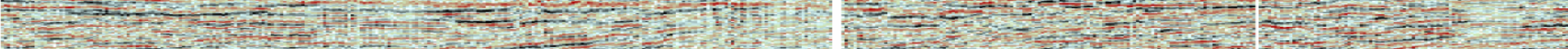

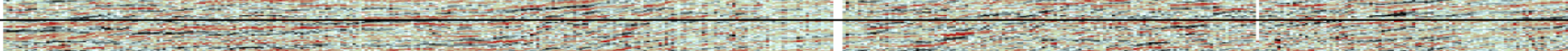

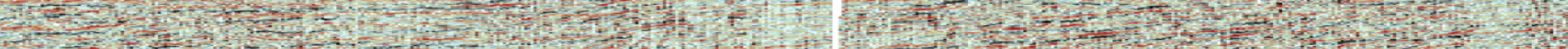
W.

1.00

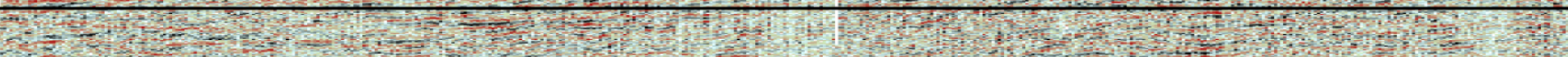
Q.7.

1.50

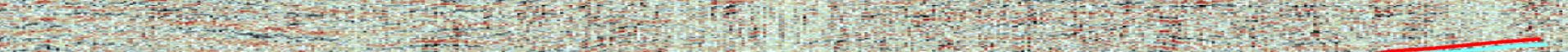

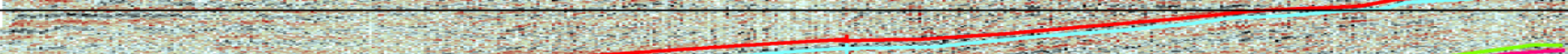

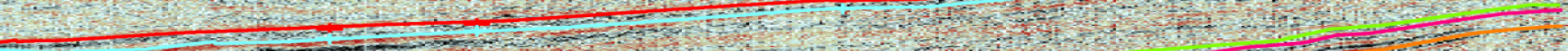

2.00 Pr. Schens

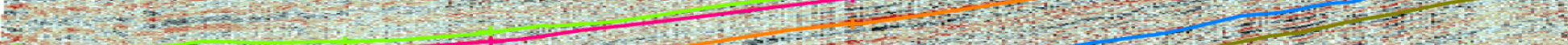

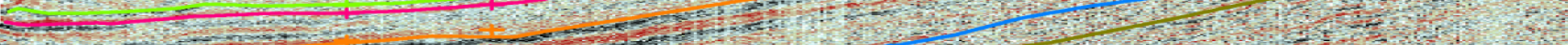

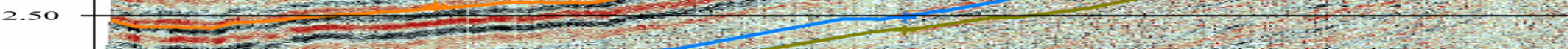

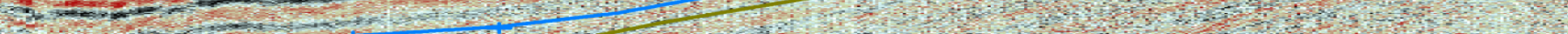

3.00

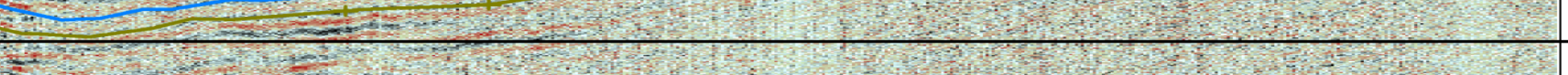

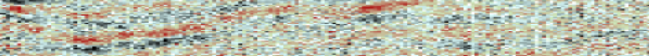

3.50

4.00

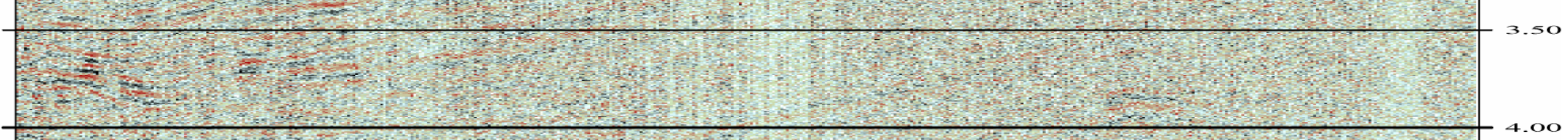

4.50

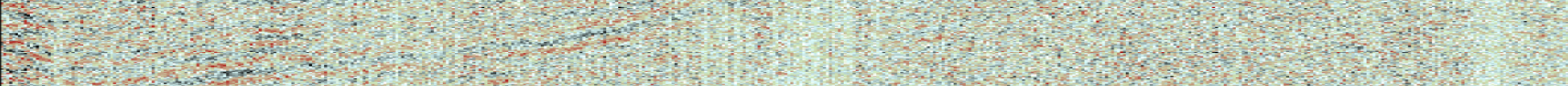
tras

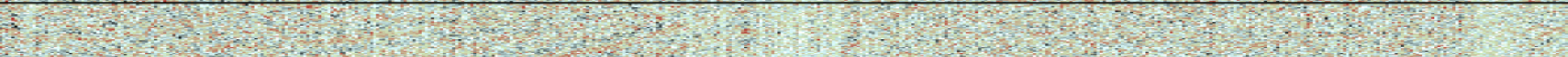
Hit.

Plate 32 - Seismic Line 136 (NAMSS, 2004) 
C-803-1 C-Chuk823-1 W-WCS-136 W-WCS-138

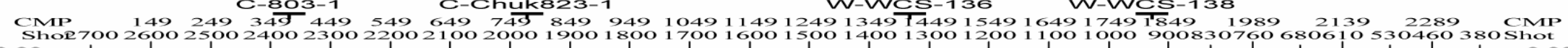

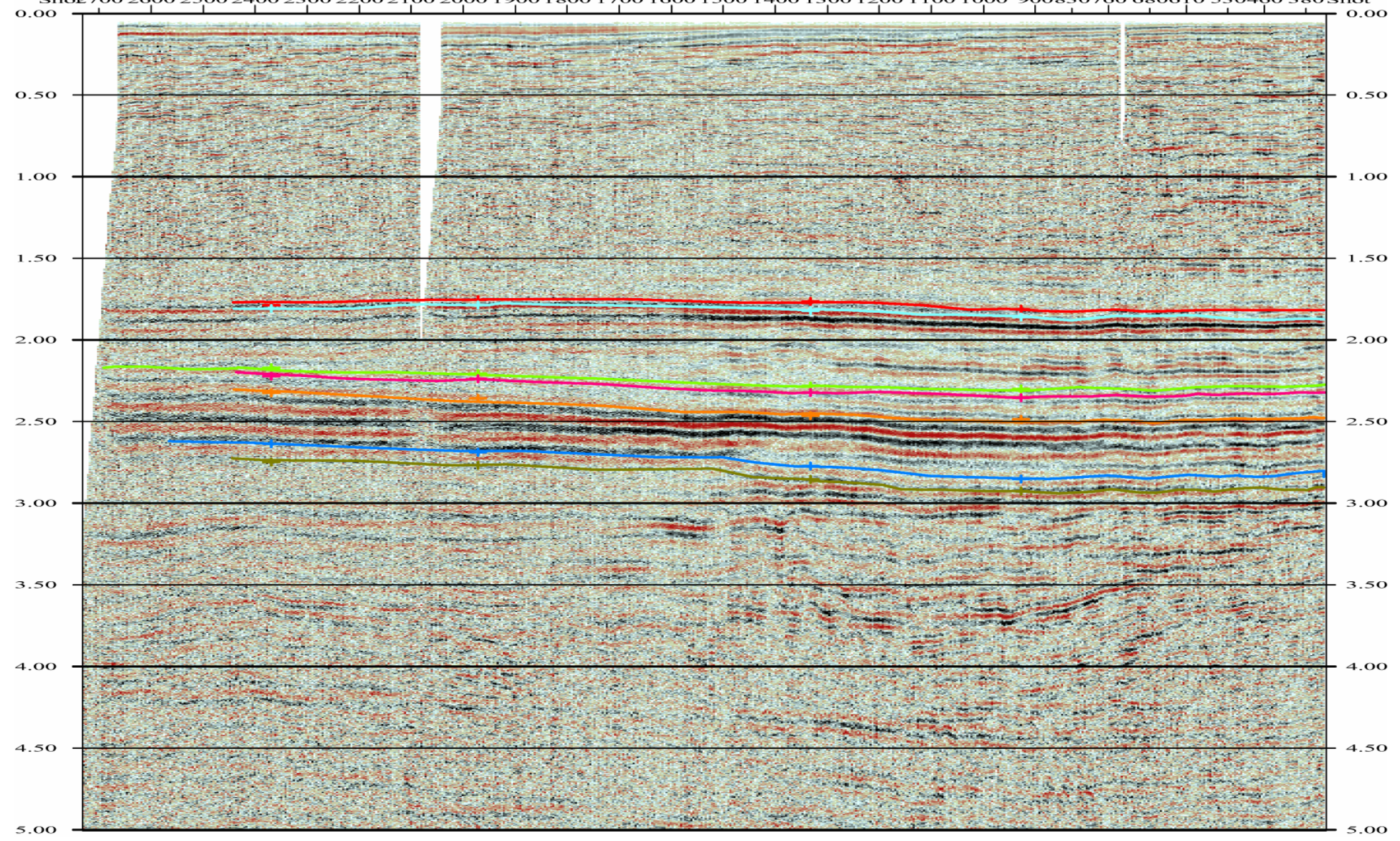

Plate 33 - Seismic Line 137 (NAMSS, 2004) 
W-WCS-137 C-Chuks23-1 W-WCS-139

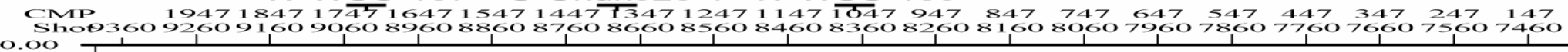

CMP Soo

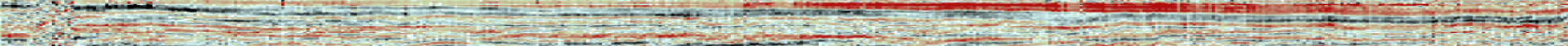

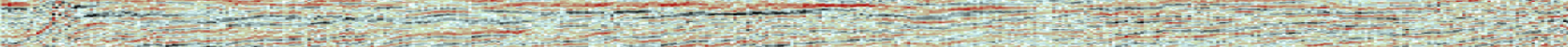

0.50

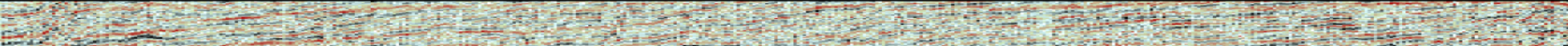

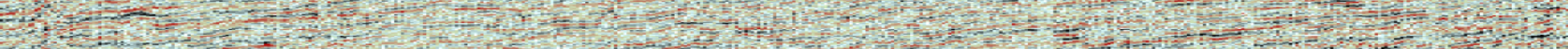

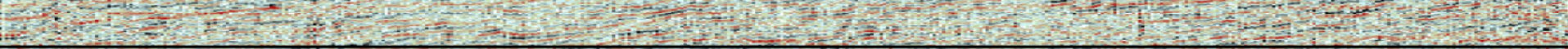

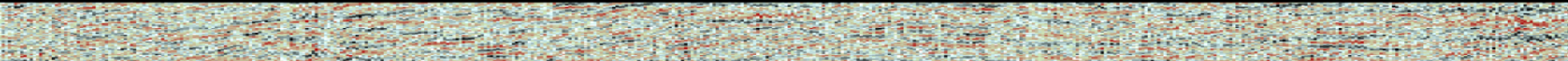

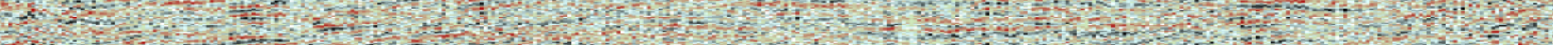

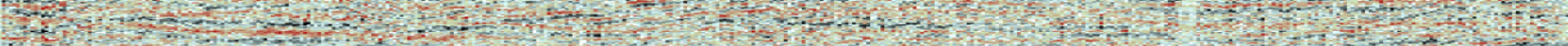

1.50

2.00

2.50

3.00

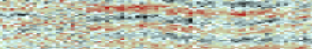

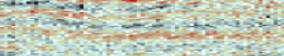
and
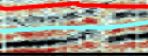

1.t.

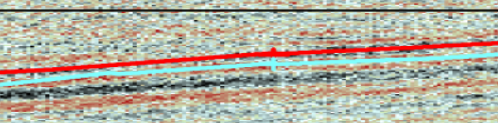

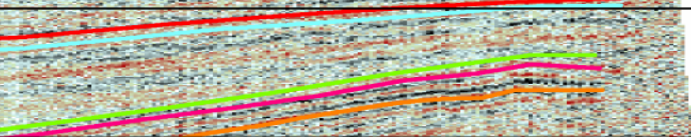
- nin

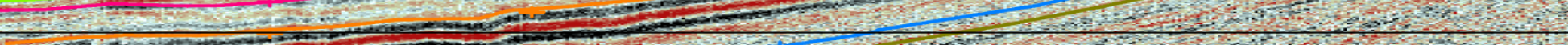

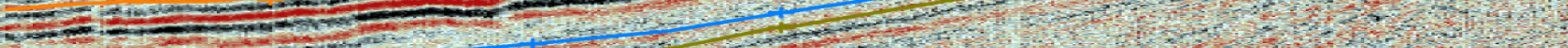

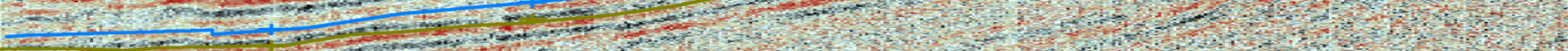
cam

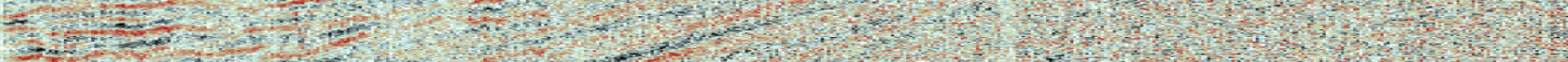
W

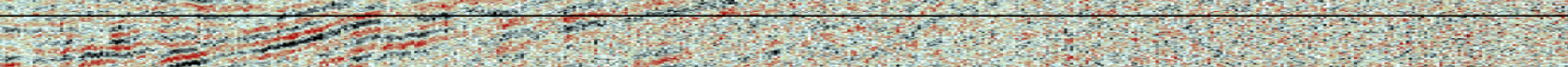
1.1.

4.00 a.

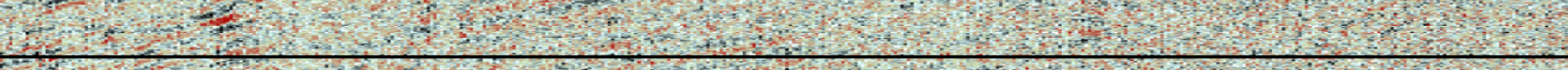

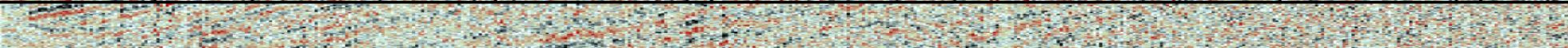

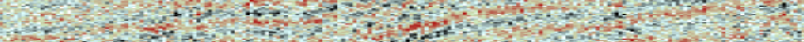

4.50

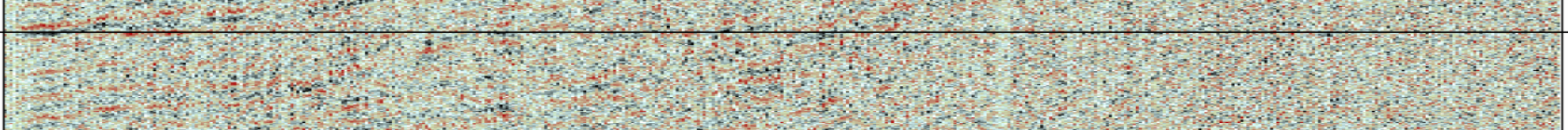

Plate 34 - Seismic Line 138 (NAMSS, 2004) 
C-803-

W-WCS-136

W-WCS-138-822-1

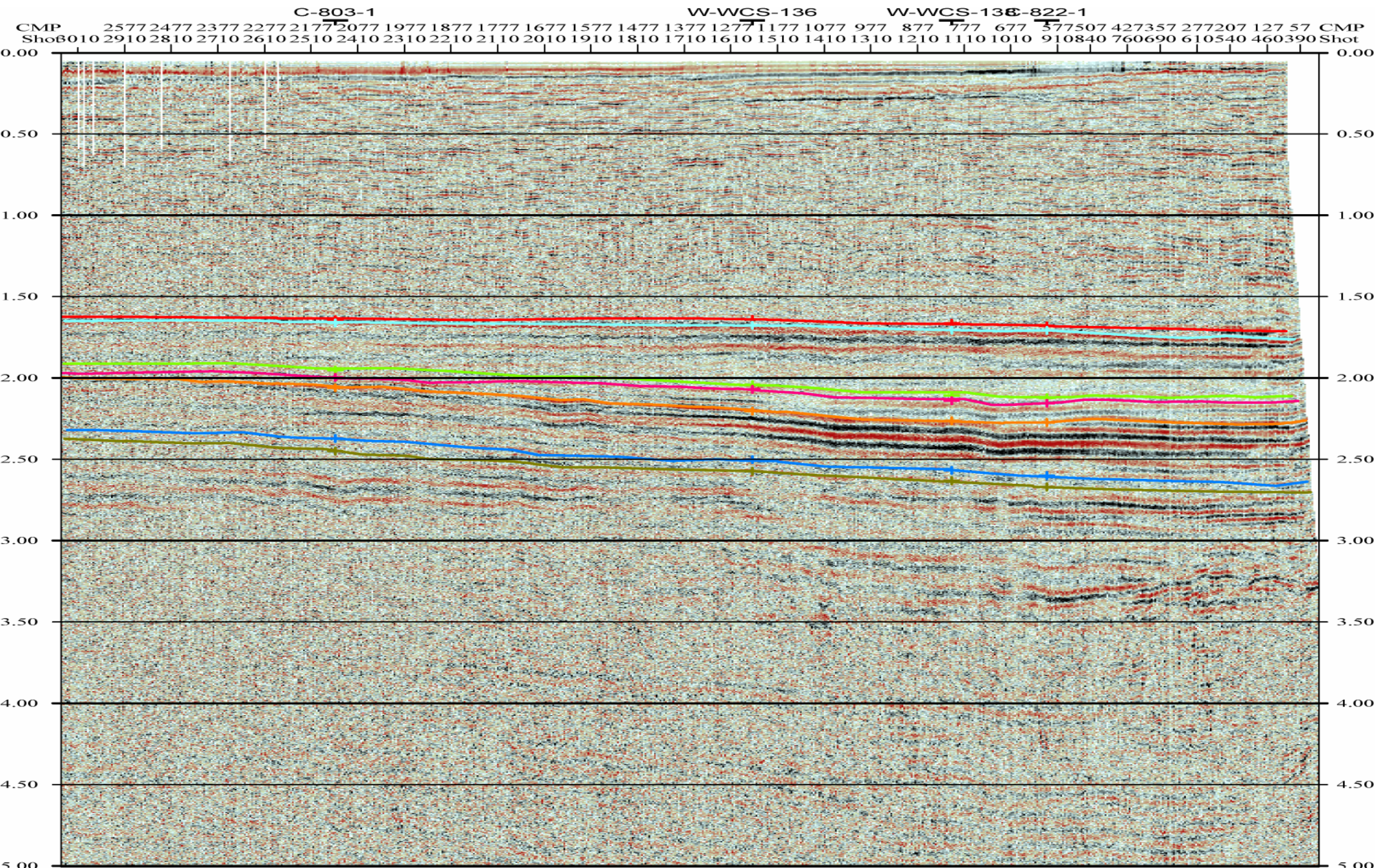

Plate 35 - Seismic Line 139 (NAMSS, 2004) 